University of South Florida

DIGITAL COMMONS

@ UNIVERSITY OF SOUTH FLORIDA
Digital Commons @ University of

South Florida

$10-2020$

\title{
Impact of COVID-19 on Travel Behavior and Shared Mobility Systems
}

CUTR

Follow this and additional works at: https://digitalcommons.usf.edu/cutr_nctr

\section{Scholar Commons Citation}

CUTR, "Impact of COVID-19 on Travel Behavior and Shared Mobility Systems" (2020). Research Reports. 254.

https://digitalcommons.usf.edu/cutr_nctr/254

This Technical Report is brought to you for free and open access by the National Center for Transit Research (NCTR) Archive (2000-2020) at Digital Commons @ University of South Florida. It has been accepted for inclusion in Research Reports by an authorized administrator of Digital Commons @ University of South Florida. For more information, please contact digitalcommons@usf.edu. 
Final Report CUTR-2020-10

\title{
Impact of COVID-19 on Travel Behavior and Shared Mobility Systems
}

\author{
Prepared For \\ National Center for Transit Research (NCTR)
}

Prepared By
USF Center for Urban Transportation Research

October 2020 


\title{
Impact of COVID-19 on Travel Behavior and Shared Mobility Systems
}

\author{
Final Report
}

Prepared for:

National Center for Transit Research (NCTR)

Prepared by:

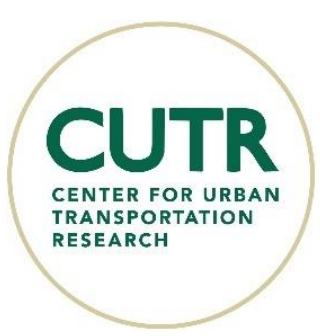

USF Center for Urban Transportation Research

Nikhil Menon, Ph.D.

Yaye Keita, Ph.D.

Robert L. Bertini, Ph.D.

October 2020 


\section{DISCLAIMER}

The contents of this report reflect the views of the authors, who are responsible for the facts and the accuracy of the information presented herein. The opinions, findings, and conclusions expressed in this report are those of the authors and not necessarily those of the National Center for Transit Research (NCTR) or the U.S. Department of Transportation. 


\section{Table of Contents}

COVID-19 Impacts on Travel Behavior and Shared Mobility ...................................................... 1

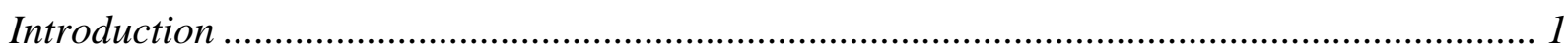

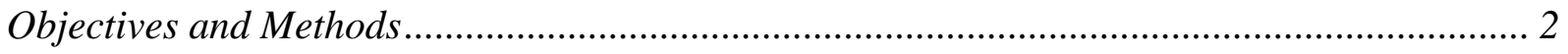

Cases, Orders, Restrictions, and Reopening Plans Across the United States .......................... 4

Coronavirus Impacts on Travel Behavior and Activity Engagement .................................. 11

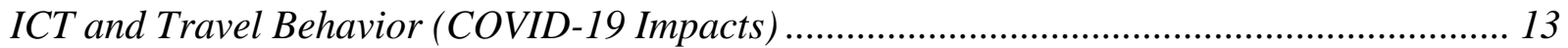

Telecommunication and E-Commerce ...................................................................... 14

Smartphones and Ride-Hailing ............................................................................. 14

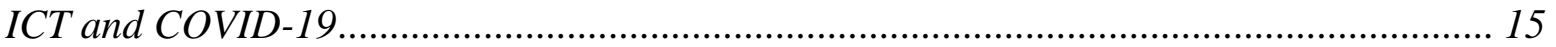

Shared Mobility System Strategies during COVID-19 Era ............................................... 16

Public Transportation Agency Strategies .................................................................. 16

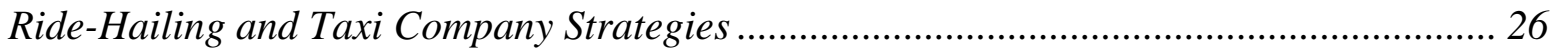

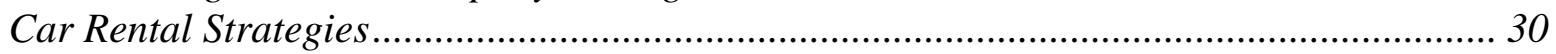

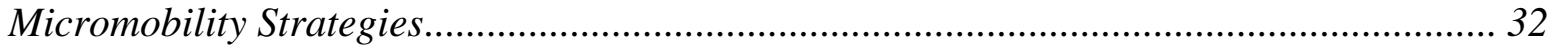

Stated Preference Survey: Some Initial Findings .................................................................... 35

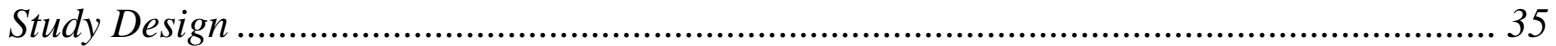

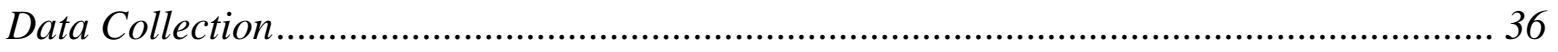

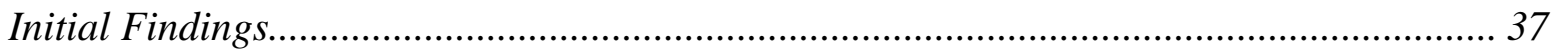

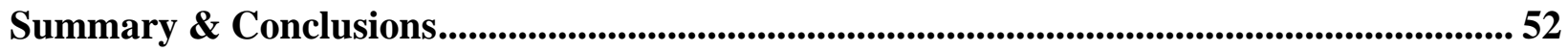

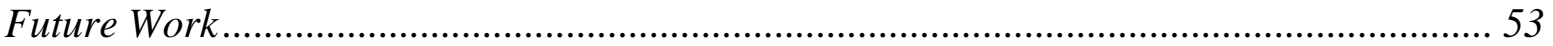

References........................................................................................................................ 55

Appendix A: Shared Mobility Characteristics.......................................................................... 62

Appendix B: Changes in Mobility Post-Lockdown..........................................................63

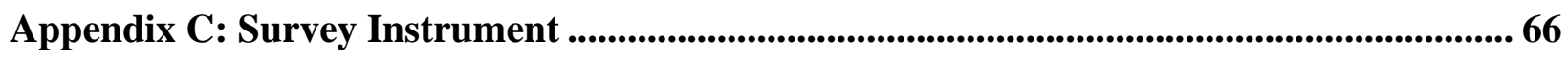




\section{List of Figures}

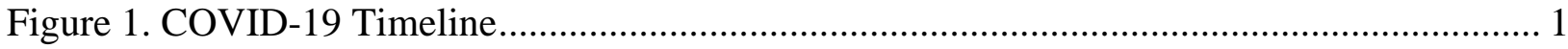

Figure 2. Cumulative Trend of Global Coronavirus Cases....................................................... 5

Figure 3. Daily Reported COVID-19 Cases in The United States ................................................ 5

Figure 4. Daily New Confirmed COVID-19 Cases Across the United States.................................. 6

Figure 5. State Wise Stay-At-Home Order Status ……………………….............................. 7

Figure 6. State Wise Reopening Dates Post COVID-19 Lockdown ............................................ 7

Figure 7. Digital Messaging Solutions to Protect Passengers and Drivers..................................... 15

Figure 8. Anti-Microbial Film Protection to Protect Frequently Touched Areas .......................... 17

Figure 9. CTA Electrostatic Sprayers for Deep Cleaning........................................................... 18

Figure 10. CTA Ridership Information Dashboard .................................................................. 19

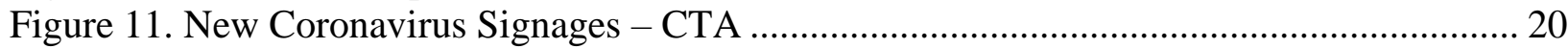

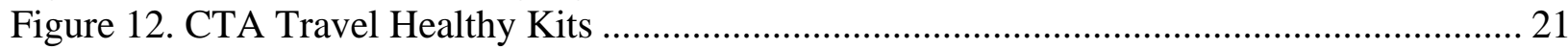

Figure 13. WMATA Cleaning Process …………………………………………………….... 22

Figure 14. TransLink Social Distancing .............................................................................. 24

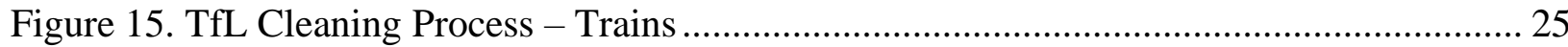

Figure 16. TfL COVID-19 Signages ................................................................................... 25

Figure 17. Precautionary Measures Adopted by Ridesharing companies during COVID-19 Crisis

Figure 18. COVID-19 Impacts on the Ridesharing Market........................................................ 28

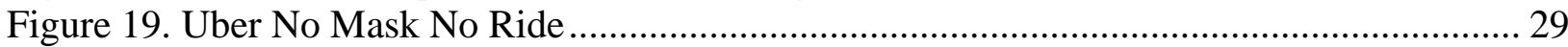

Figure 20. Uber Eats Food Delivery Service ........................................................................... 29

Figure 21. Example Car Rental Process During COVID-19 Pandemic ........................................ 31

Figure 22. Example Car Rental Cleaning Procedures .................................................................. 31

Figure 23. Micromobility Post-Pandemic Recovery ............................................................... 32

Figure 24. Micromobility Users' Top Concerns - Pre- and Post-COVID-19 ………………....... 33

Figure 25. Pop-up Bike Lanes in Berlin (Germany) .................................................................... 34

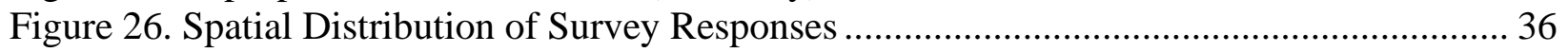

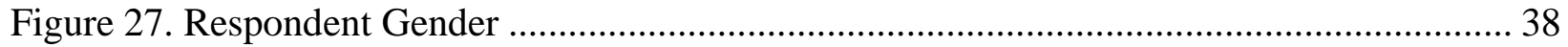

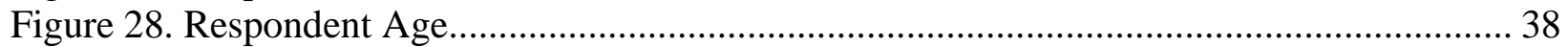

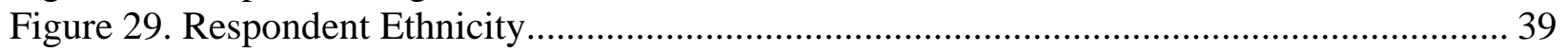

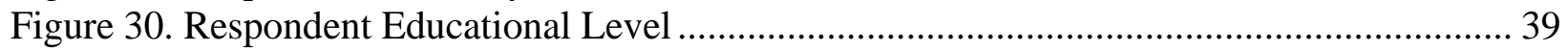

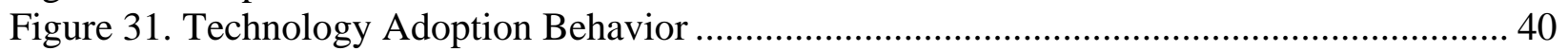

Figure 32. Annual Household Income ..................................................................................... 40

Figure 33. Respondent Household Information ........................................................................ 41

Figure 34. Household Vehicles - Before and During COVID-19 ............................................... 42

Figure 35. Vehicles Purchased and Sold During COVID-19 ………........................................... 42

Figure 36. Work from Home - Before, During, and After COVID-19 ....................................... 44

Figure 37. Commute Mode Choice - Before, During, and After COVID-19 ……….................... 45

Figure 38. Shared Mobility Usage - After COVID-19.................................................................. 46

Figure 39. Respondent Opinion on Getting COVID-19 by Using Shared Mobility Modes......... 47

Figure 40. Respondent's Trust Level on Infection Prevention Measures Implemented by Shared

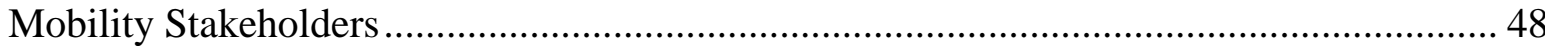

Figure 41. Respondent's Opinions on Using Shared Mobility Systems........................................ 49

Figure 42. Future Activity Participation in the Era of the Pandemic............................................. 50 


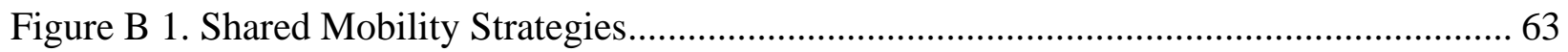

Figure B 2. Change in Travel Behavior Immediately Post-Lockdown ................................... 63

Figure B 3. Change in Travel Behavior Over Time Post-Lockdown ......................................... 64

Figure B 4. Change in User Loyalty Post-Lockdown ........................................................... 64

Figure B 5. Anticipated Spending on Various Modes Post-Lockdown................................... 65

\section{List of Tables}

Table 1. Shared Mobility Definitions ...................................................................................... 3

Table 2. An Overview of State Wise COVID-19 Orders and Restrictions in the United States (as

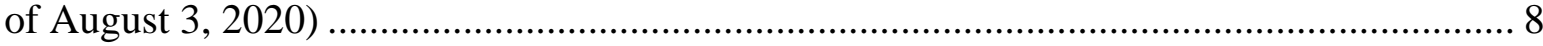

Table A 1. Examples of Shared Mobility Characteristics................................................... 62 


\section{COVID-19 Impacts on Travel Behavior and Shared Mobility}

\section{Introduction}

In the past several months, the novel coronavirus (COVID-19) or severe acute respiratory syndrome coronavirus 2 (SARS-CoV-2), has developed into a catastrophic global phenomenon with multiple impacts on the health and well-being of people, as well as far-reaching impacts across different industries and business sectors. The course of this virus began in Wuhan, China, and with time spread around the globe. As a result of the virus, the U.S. declared a national emergency on March 13, 2020, and in a couple of weeks, most of the U.S. population was subject to the social distancing orders to curb the spread of the virus and the subsequent infections. These restrictions were relaxed in a phase-wise manner (based on the prevalence in states/cities) starting from May 2020. A succinct timeline of the coronavirus pandemic is provided in Figure 1.

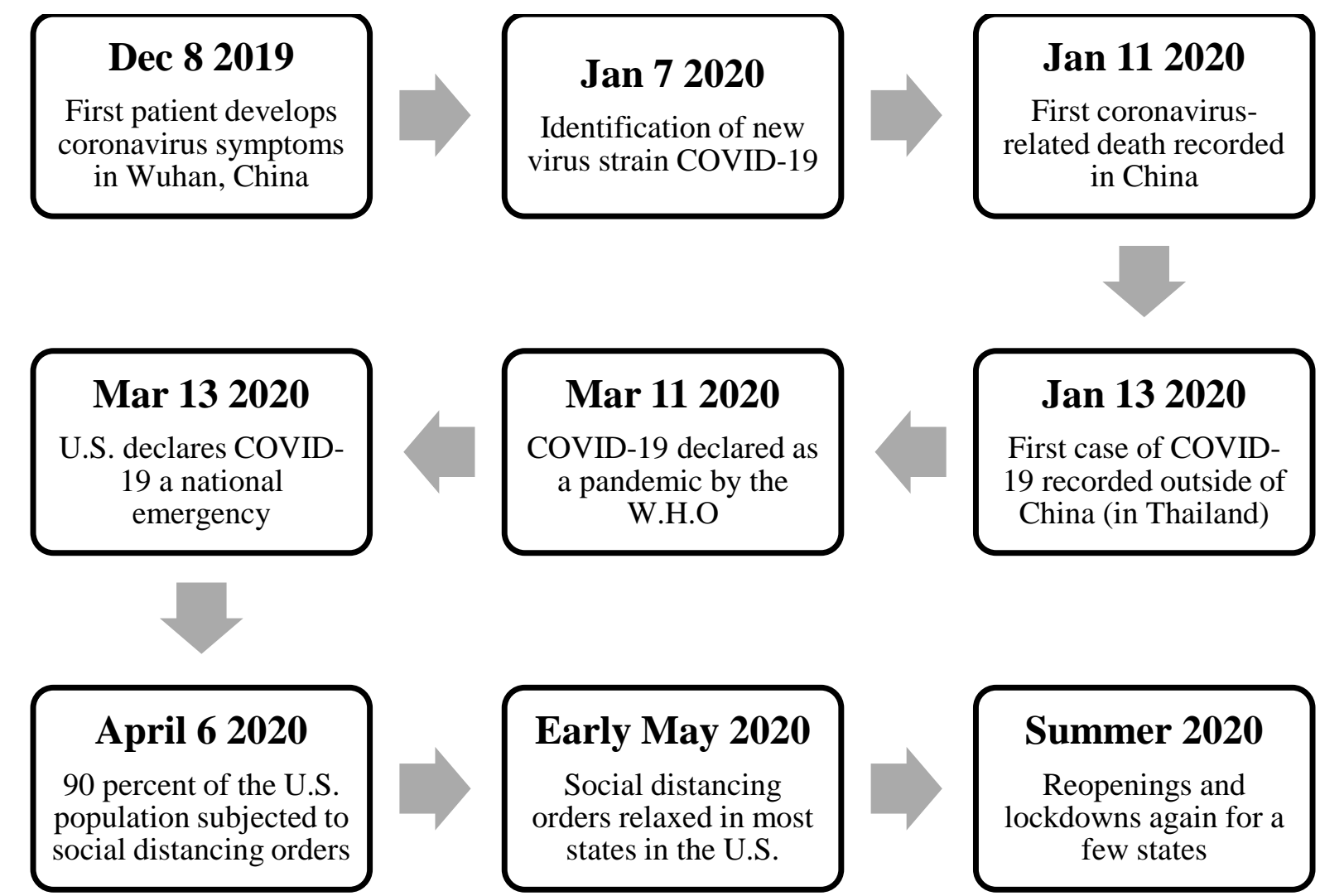

Figure 1. COVID-19 Timeline

As was the case with many industries, the transportation sector was severely impacted by the emergence of this global health crisis, and the ensuing social distance norms that have been put in place by governments at different levels across the world. From a transportation perspective, 
the novel coronavirus also has had a profound impact on travel behavior, mobility, air quality, environment, as well as on logistics and supply chains on a global basis. Individuals' movements across the globe became static during these unprecedented times with suspended air and ground transportation. Consumer demand for private and public transportation rides has significantly decreased (Molloy et al., 2020). Considering the nature of the virus spread and the potentially fatal consequences, countries across the world have been doubling down on using public transportation and shared transportation modes (DfT, 2020), and organizations in the United States have been advised to incentivize their employees for using transportation modes that minimize the prospect of close contact with fellow users (CDC 2020). The currently circumstances directly contrast the original philosophy behind embracing these modes for our travel needs. As a consequence, transportation agencies have been under financial duress, not to mention the impact that the current predicament has had on communities that are transitdependent (for the lack of an alternative, in some cases) to fulfill their mobility needs. Keeping these considerations in mind, several transportation providers have been working to adapt and survive with new business models, and practices.

\section{Objectives and Methods}

As the COVID-19 outbreak continues to evolve, transportation systems must adapt quickly to satisfy the needs of this new reality. This necessitates further studies to understand and develop strategies that can be used to navigate this new reality, mitigate the effects from potential contagion spread, and achieve positive and healthful outcomes at a system-level. With the aim to understand some of these pressing challenges, the research team conducted a study to investigate the impact of COVID-19 on travel behavior, active engagement, shared mobility, and to understand the role played by information and communication technologies (ICT) in the current environment. The main objectives of this research study are to better understand the impacts of the global pandemic on current and future travel behavior, activity engagement, and overall trip making with special focus on shared mobility systems.

The first section of this report is a comprehensive review of web-based material on the strategies embraced by shared transportation providers to tackle the new normal posed by the coronavirus pandemic. Inclusion criteria for the web review are news articles posted on web media, press releases made by transportation agencies, technical reports from academia and the industry, journal papers, and webcasts that have been made publicly available from December 2019 to July 2020. The research team began by assessing COVID-19 related trends and orders, as well as its impacts on travel behavior and shared mobility systems. This was followed by the documentation of strategies employed by various shared mobility providers during the pandemic. The research team supplemented information on strategies obtained online with webinars on public transportation and COVID-19, such as "The Vital Role of Public Transportation in Reopening Our Cities" (NICTR, 2020) The highlighted webcasts interviewed five major agency leaders across the world, with three of these agencies located in the U.S., one in Canada, one in 
London, and one international public transportation organization in Europe. Information obtained from the webcasts was also verified on organization websites.

For the web review, Google and Google Scholar were used to systematically search for documents including the combination of the following keywords 'transportation', 'COVID-19', 'pandemic,' 'shared mobility,' 'public transportation,' 'micromobility,' 'ride-hailing,' 'bikesharing,' 'car rental,' 'ride-sharing,' and 'taxi.' The review focused on literature compiled during the analysis timeline. Although the information on mobility across the world is included, the research focused on mobility impacts and strategies in the U.S. Snowballing techniques were used to collect additional information.

Overall, the FTA definitions of shared mobility are adopted in this research, which include public transit, paratransit, demand-responsive services, bike-sharing, carsharing, microtransit, and ride-sourcing services as provided by companies such as Uber and Lyft (FTA, 2020). Additional details related to each type of shared mobility systems are available in Table 1.

Table 1. Shared Mobility Definitions

\begin{tabular}{|c|c|c|}
\hline Term & Definition & $\begin{array}{l}\text { Alternative } \\
\text { Terms }\end{array}$ \\
\hline Bikesharing & $\begin{array}{l}\text { Short-term bike rental, usually for individual periods of an hour or less over } \\
\text { the course of a membership (periods which can range from a single ride, to } \\
\text { several days, to an annual membership). Information technology-enabled } \\
\text { public bikesharing provides real-time information about the location and } \\
\text { demand for bikes at docking stations throughout a community. }\end{array}$ & \\
\hline Carsharing & $\begin{array}{l}\text { A service that provides members with access to an automobile for intervals of } \\
\text { less than a day. Major carsharing business models include traditional or } \\
\text { round-trip, which requires users to borrow and return vehicles at the same } \\
\text { location; one-way or free-floating, which allows users to pick up a vehicle at } \\
\text { one location and drop it off at another; and peer-to-peer (p2p), which allows } \\
\text { car owners to earn money at times when they are not using their vehicles by } \\
\text { making them available for rental to other carshare members. }\end{array}$ & \\
\hline $\begin{array}{l}\text { Demand } \\
\text { Responsive } \\
\text { System }\end{array}$ & $\begin{array}{l}\text { A system of transporting individuals (other than by aircraft), including the } \\
\text { provision of designated public transportation service by public entities and } \\
\text { the provision of transportation service by private entities, including, but not } \\
\text { limited to, specified transportation service, which is not a fixed route system. }\end{array}$ & $\begin{array}{l}\text { Demand- } \\
\text { response } \\
\text { System }\end{array}$ \\
\hline $\begin{array}{l}\text { Fixed-route } \\
\text { system }\end{array}$ & $\begin{array}{l}\text { A system of transporting individuals (other than by aircraft), including the } \\
\text { provision of designated public transportation service by public entities and } \\
\text { the provision of transportation service by private entities, including, but not } \\
\text { limited to, specific public transportation service, on which a vehicle is } \\
\text { operated along a prescribed route according to a fixed schedule. }\end{array}$ & \\
\hline Microtransit & $\begin{array}{l}\text { IT-enabled private multi-passenger transportation services, such as Bridj, } \\
\text { Chariot, Split, and Via, that serve passengers using dynamically generated } \\
\text { routes, and may expect passengers to make their way to and from common } \\
\text { pick-up or drop-off points. Vehicles can range from large SUVs to vans to } \\
\text { shuttle buses. Because they provide transit-like service but on a smaller, more } \\
\text { flexible scale, these new services have been referred to as microtransit. }\end{array}$ & \\
\hline $\begin{array}{l}\text { Mobility on } \\
\text { Demand }\end{array}$ & $\begin{array}{l}\text { An integrated and connected multi-modal network of safe, affordable, and } \\
\text { reliable transportation options that are available and accessible to all } \\
\text { travelers. }\end{array}$ & \\
\hline Paratransit & $\begin{array}{l}\text { Comparable transit service required by the Americans with Disabilities Act } \\
\text { for individuals with disabilities who are unable to use fixed route } \\
\text { transportation systems. }\end{array}$ & \\
\hline
\end{tabular}




\begin{tabular}{|c|c|c|}
\hline $\begin{array}{l}\text { Private } \\
\text { shuttles }\end{array}$ & $\begin{array}{l}\text { Corporate, regional, and local shuttles that make limited stops, often only } \\
\text { picking up specified riders. }\end{array}$ & $\begin{array}{l}\text { Employer } \\
\text { shuttle, tech } \\
\text { buses }\end{array}$ \\
\hline $\begin{array}{l}\text { Public } \\
\text { transportation }\end{array}$ & $\begin{array}{l}\text { Regular, continuing shared-ride surface transportation services that are open } \\
\text { to the general public or open to a segment of the general public defined by } \\
\text { age, disability, or low income. Public transportation does not include: } \\
\text { intercity passenger rail transportation (provide by Amtrak, or any successor); } \\
\text { intercity bus service; charter bus service; school bus service; sightseeing } \\
\text { service; courtesy shuttle service for patrons of one or more specific } \\
\text { establishments; or intra-terminal or intra-facility shuttle services. }\end{array}$ & \\
\hline Ridesharing & $\begin{array}{l}\text { Ridesharing involves adding passengers to a private trip in which driver and } \\
\text { passengers share a destination. Such an arrangement provides additional } \\
\text { transportation options for riders while allowing drivers to fill otherwise } \\
\text { empty seats in their vehicles. Traditional forms of ridesharing include } \\
\text { carpooling and vanpooling. This term is sometimes used to refer to } \\
\text { ridesourcing. }\end{array}$ & $\begin{array}{l}\text { Carpooling, } \\
\text { vanpooling, } \\
\text { slugging, } \\
\text { ridesourcing }\end{array}$ \\
\hline Ridesourcing & $\begin{array}{l}\text { Use of online platforms to connect passengers with drivers and automate } \\
\text { reservations, payments, and customer feedback. Riders can choose from a } \\
\text { variety of service classes, including drivers who use personal, non- } \\
\text { commercial, vehicles; traditional taxicabs dispatched via the providers' apps, } \\
\text { and premium services with professional livery drivers and vehicles. } \\
\text { Ridesourcing has become one of the most ubiquitous forms of shared } \\
\text { mobility. }\end{array}$ & $\begin{array}{l}\text { Transportation } \\
\text { network } \\
\text { company } \\
\text { (TNC0, } \\
\text { ridesharing, e- } \\
\text { hailing }\end{array}$ \\
\hline Ride-splitting & $\begin{array}{l}\text { A type of ridesourcing that allow customers requesting a ride for one or two } \\
\text { passengers to be paired in real time with others traveling along a similar } \\
\text { route. }\end{array}$ & $\begin{array}{l}\text { Dynamic } \\
\text { carpooling }\end{array}$ \\
\hline $\begin{array}{l}\text { Shared-Use } \\
\text { Mobility }\end{array}$ & $\begin{array}{l}\text { Transportation services that are shared among users, including public transit; } \\
\text { taxis and limos; bikesharing; carsharing (round-trip, one-way, and personal } \\
\text { vehicle sharing); ridesharing (car-pooling, van-pooling); ridesourcing; } \\
\text { scooter sharing; shuttle services; neighborhood jitneys; and commercial } \\
\text { delivery vehicles providing flexible goods movement. }\end{array}$ & $\begin{array}{l}\text { Shared } \\
\text { mobility }\end{array}$ \\
\hline $\begin{array}{l}\text { Specified } \\
\text { public } \\
\text { transportation }\end{array}$ & $\begin{array}{l}\text { Transportation by bus, rail, or any other conveyance (other than aircraft) } \\
\text { provided by a private entity to the general public, with general or special } \\
\text { service (including charter service) on a regular and continuing basis. }\end{array}$ & \\
\hline
\end{tabular}

(Source: FTA, 2020)

\section{Cases, Orders, Restrictions, and Reopening Plans Across the United States}

Since December 2019 (and as of August 3, 2020), the global COVID-19 crisis has caused close to half a million deaths in the world and thousands in the United States leading to orders and restrictions on travel and outdoor activities. There has been an exponential rise in the number of cases globally in the past five months (March to August 2020) with an increasing number of deaths being reported across countries globally (see Figure 2). Looking at the United States alone, even though the seven-day rolling average showed a decreasing trend a month after a national emergency was declared, coronavirus cases have had an exponential increase in the time period since then (refer to Figure 3 below). 


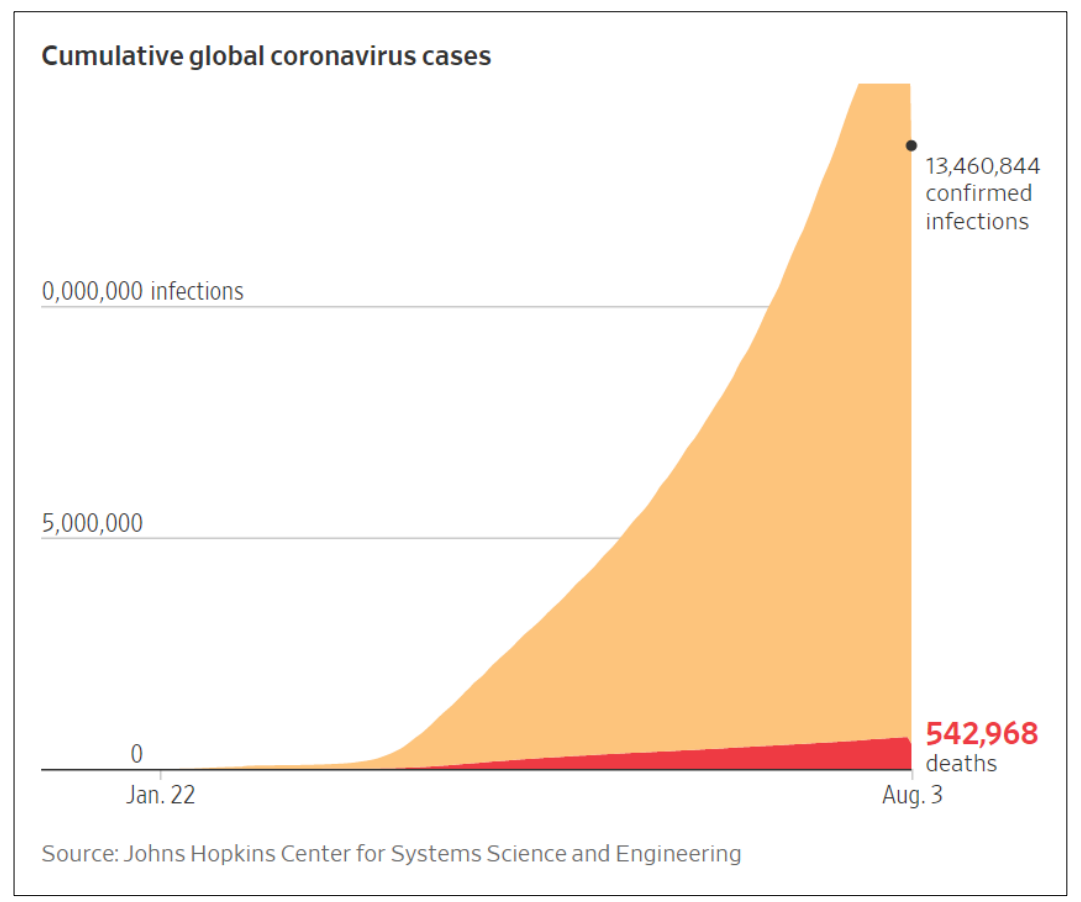

Figure 2. Cumulative Trend of Global Coronavirus Cases (Source: Gershman, 2020 [Accessed August 3, 2020])

\section{Daily reported Covid-19 cases in the U.S.}

- Seven-day rolling average

80,000 cases

60,000

40,000

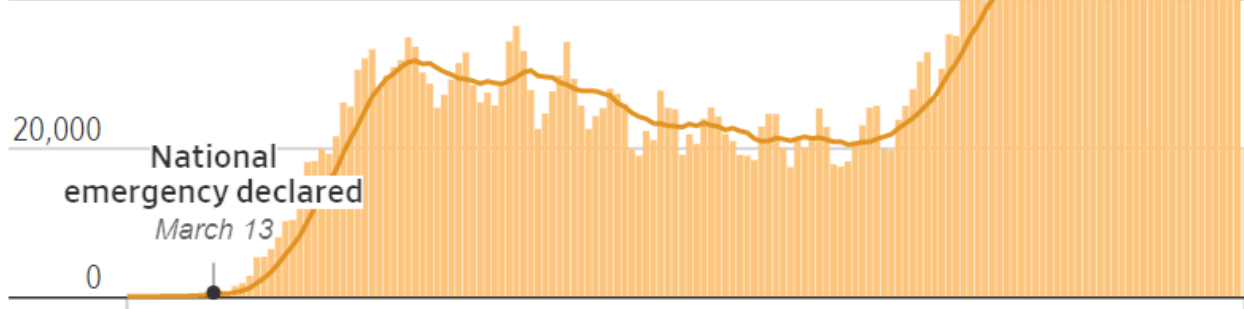

March 1

Note: For all 50 states and D.C., U.S. territories and cruises. Last updated August 3, at 2:10 p.m. Source: Johns Hopkins Center for Systems Science and Engineering

Figure 3. Daily Reported COVID-19 Cases in The United States (Source: Gershman, 2020 [Accessed August 3, 2020]) 
As mentioned above, the risks associated with the virus have dramatically affected our transportation systems in numerous ways. Exposure to the virus, whether related to using public transportation or other shared transportation modes, can depend on geographic locations and the rates of new reported cases in local communities. This section of the report illustrates the geographic and temporal variations of COVID-19 cases, orders, restrictions, reopening plans across the United States. Existing work and literature on this subject demonstrate that the rates of new cases vary by states (see Figure 4).

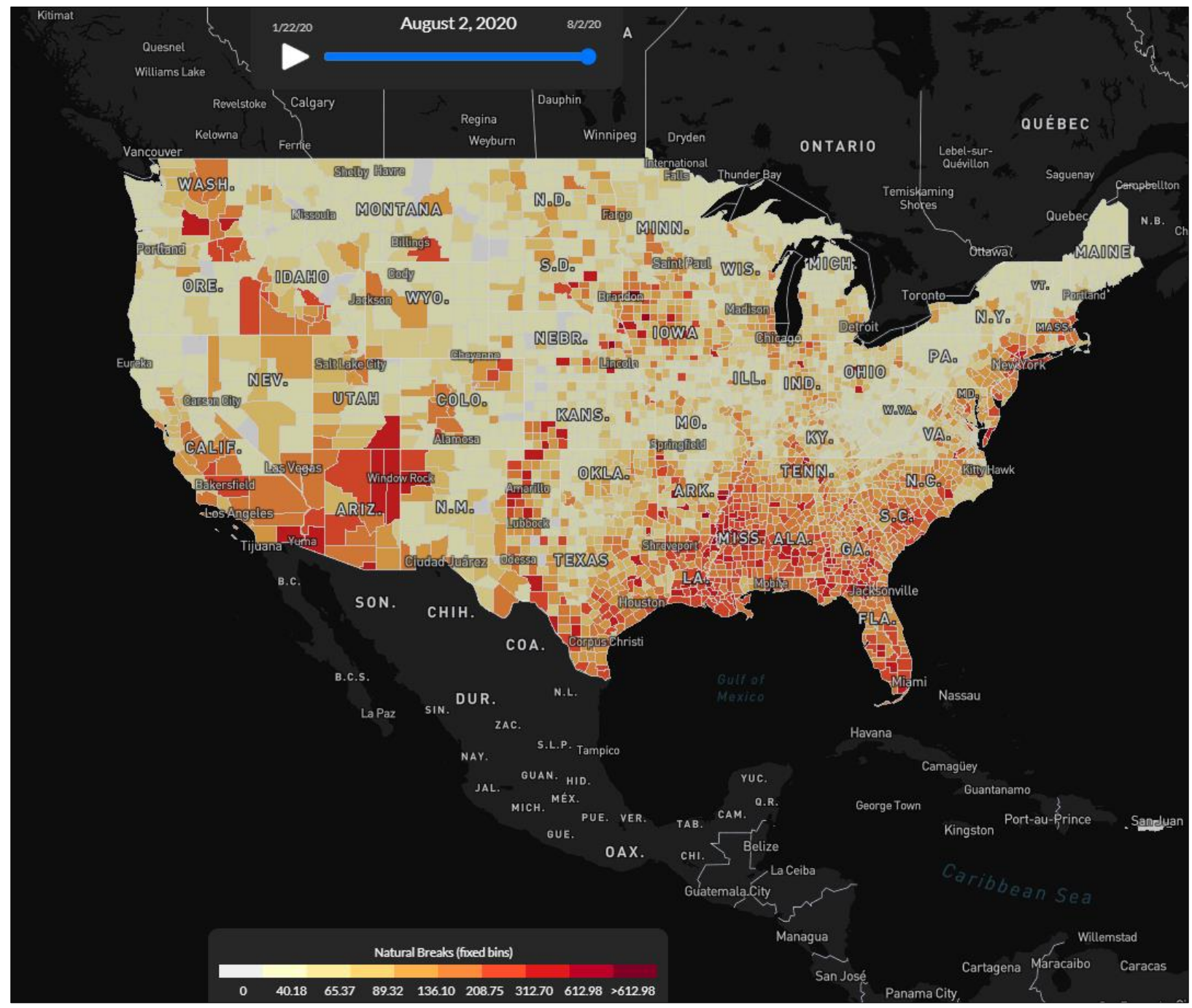

Figure 4. Daily New Confirmed COVID-19 Cases Across the United States (Source: Li et al., 2020 [Accessed August 3, 2020])

For instance, although many of the states issued stay-at-home orders during the pandemic, a few states were not subject to such orders (see Figure 5). The COVID-19-related business and travel restrictions, as well as the reopening plans, have also been far from uniform across the country (see Figure 5 and Error! Reference source not found.). 


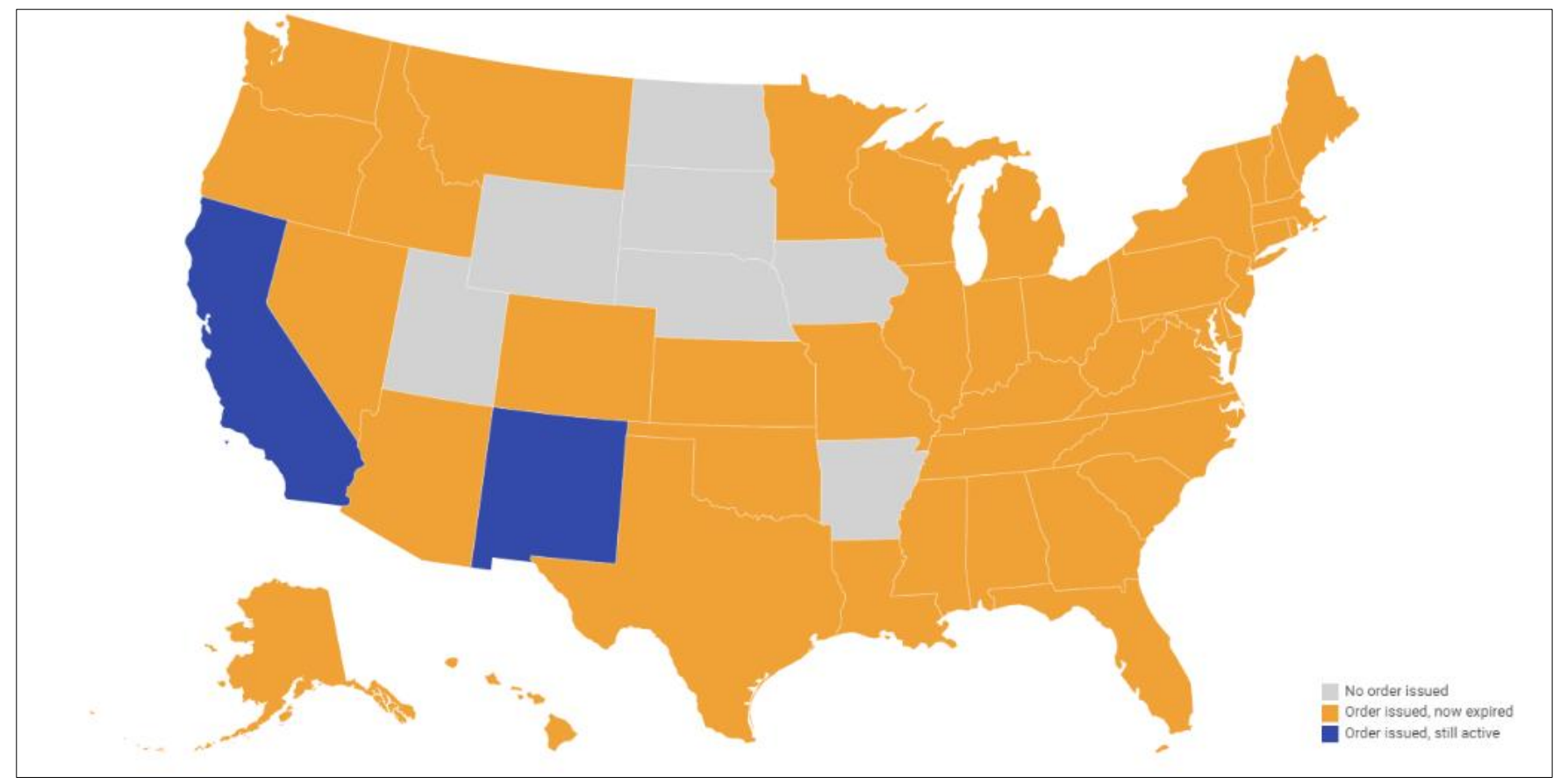

Figure 5. State Wise Stay-At-Home Order Status

(Source: Ballotpedia, 2020 [Accessed August 3, 2020])

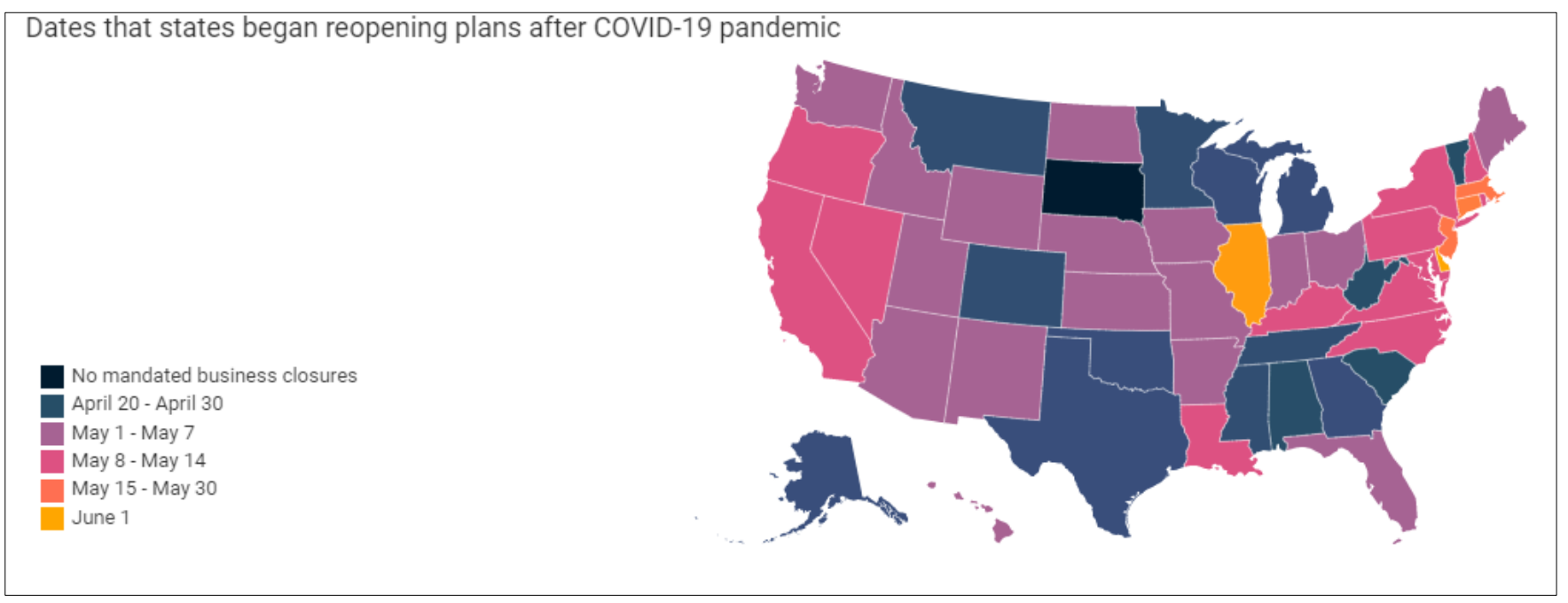

Figure 6. State Wise Reopening Dates Post COVID-19 Lockdown

(Source: Ballotpedia, 2020 [Accessed August 3, 2020])

A breakdown of the various COVID-19 restrictions by states is also as shown in Table 2. An Overview of State Wise COVID-19 Orders and Restrictions 
Table 2. An Overview of State Wise COVID-19 Orders and Restrictions in the United States (as of August 3, 2020)

\begin{tabular}{|c|c|c|c|c|c|c|c|c|}
\hline State & $\begin{array}{c}\text { Stay at } \\
\text { home } \\
\text { effective }\end{array}$ & $\begin{array}{l}\text { Stay at } \\
\text { home } \\
\text { relaxed }\end{array}$ & $\begin{array}{c}\text { Travel outside } \\
\text { home (e.g., } \\
\text { excluding older and } \\
\text { at-risk residents) }\end{array}$ & $\begin{array}{c}\text { Gatherings } \\
\text { (non-work or } \\
\text { non-religious, } \\
\text { and without } 6 \mathrm{ft} \\
\text { distance rules) }\end{array}$ & $\begin{array}{c}\text { Businesses } \\
\text { reopened } \\
\text { (with } \\
\text { sanitation and } \\
\text { social } \\
\text { distancing) }\end{array}$ & $\begin{array}{l}\text { Quarantines (e.g., } \\
\text { out of state } \\
\text { travelers must } \\
\text { quarantine for } 14 \\
\text { days) }\end{array}$ & $\begin{array}{c}\text { Restaurants } \\
\text { reopened (dine-in } \\
\text { with reduced } \\
\text { capacity and } \\
\text { social distancing, } \\
\text { no bars) }\end{array}$ & $\begin{array}{l}\text { Beaches/ parks } \\
\text { reopened (with } \\
\text { social- } \\
\text { distancing for } \\
\text { day-use) }\end{array}$ \\
\hline Alabama & 4-Apr & 30-Apr & Not encouraged & Prohibited & Yes & No directive & Dine-out only & Yes \\
\hline Alaska & 28-Mar & 21-Apr & $\mathrm{OK}$ & 20-person limit & $\begin{array}{c}\text { With } \\
\text { limitations }\end{array}$ & Yes & With reservations & Yes \\
\hline Arizona & 31-Mar & 15-May & Not encouraged & Not encouraged & Yes & No directive & Yes & Yes \\
\hline Arkansas & None & None & No order & 10-person limit & $\begin{array}{c}\text { With } \\
\text { limitations }\end{array}$ & Yes & With restrictions & Yes \\
\hline California & 19-Mar & $\begin{array}{c}\text { No Fixed } \\
\text { end date }\end{array}$ & $\begin{array}{c}\text { Essential needs/work } \\
\text { only }\end{array}$ & Prohibited & No & No directive & Dine-out only & Limited access \\
\hline Colorado & 26-Mar & 26-Apr & Not encouraged & 10-person limit & $\begin{array}{c}\text { With } \\
\text { restrictions }\end{array}$ & No directive & Dine-out only & $\begin{array}{l}\text { Yes, with } \\
\text { restrictions }\end{array}$ \\
\hline Connecticut & 23-Mar & 20-May & Not encouraged & 5-person limit & $\begin{array}{c}\text { With } \\
\text { limitations }\end{array}$ & $\begin{array}{c}\text { Encouraged for } \\
\text { visitors }\end{array}$ & $\begin{array}{l}\text { Dine-out and } \\
\text { outdoor only }\end{array}$ & Yes \\
\hline Delaware & 24-Mar & 31-May & $\begin{array}{c}\text { Essential needs/work } \\
\text { only }\end{array}$ & 10-person limit & $\begin{array}{c}\text { With } \\
\text { limitations }\end{array}$ & For visitors & Dine-out only & Limited access \\
\hline Florida & 3-Apr & 4-May & $\mathrm{OK}$ & Not encouraged & Yes & $\begin{array}{c}\text { For visitors from } \\
\text { hot spots }\end{array}$ & Yes & Yes \\
\hline Georgia & 3-Apr & 30-Apr & $\begin{array}{c}\text { OK, with } \\
\text { masks/social } \\
\text { distancing }\end{array}$ & 10-person limit & $\begin{array}{c}\text { With } \\
\text { limitations }\end{array}$ & No directive & Yes & Yes \\
\hline Hawaii & 25-Mar & 31-May & $\begin{array}{c}\text { Essential needs/work } \\
\text { only }\end{array}$ & 10-person limit & $\begin{array}{c}\text { With } \\
\text { limitations }\end{array}$ & Yes & Dine-out only & Limited access \\
\hline Idaho & 25-Mar & 30-Apr & Not encouraged & Not encouraged & $\begin{array}{c}\text { With } \\
\text { limitations }\end{array}$ & Yes & Dine-out only & Limited access \\
\hline Illinois & 21-Mar & 29-May & $\begin{array}{l}\text { Essential needs/work } \\
\text { only }\end{array}$ & Prohibited & $\begin{array}{c}\text { With } \\
\text { limitations }\end{array}$ & No directive & Dine-out only & Limited access \\
\hline Indiana & 24-Mar & 3-May & Not encouraged & 25-person limit & $\begin{array}{c}\text { Yes, at } 50 \% \\
\text { capacity }\end{array}$ & No directive & $\begin{array}{c}\text { Yes, at } 50 \% \\
\text { capacity }\end{array}$ & Yes \\
\hline
\end{tabular}




\begin{tabular}{|c|c|c|c|c|c|c|c|c|}
\hline Iowa & None & None & No order & 10-person limit & Yes & No directive & Yes & Yes \\
\hline Kansas & 30-Mar & 3-May & Not encouraged & 10-person limit & Yes & Yes & Yes & Yes \\
\hline Kentucky & 26-Mar & $\begin{array}{l}\text { No Fixed } \\
\text { end date }\end{array}$ & Not encouraged & small gatherings & $\begin{array}{c}\text { With } \\
\text { limitations }\end{array}$ & $\begin{array}{c}\text { Encouraged for } \\
\text { visitors }\end{array}$ & Dine-out only & Limited access \\
\hline Louisiana & 23-Mar & 15-May & $\begin{array}{c}\text { Essential needs/work } \\
\text { only }\end{array}$ & Not encouraged & $\begin{array}{c}\text { With } \\
\text { limitations }\end{array}$ & No directive & Yes & Limited access \\
\hline Maine & 2-Apr & 31-May & $\begin{array}{c}\text { Essential needs/work } \\
\text { only }\end{array}$ & 10-person limit & $\begin{array}{c}\text { With } \\
\text { limitations }\end{array}$ & Yes & Dine-out only & Limited access \\
\hline Maryland & 30-Mar & 15-May & $\begin{array}{c}\text { Essential needs/work } \\
\text { only }\end{array}$ & 10-person limit & $\begin{array}{c}\text { With } \\
\text { limitations }\end{array}$ & Yes & Dine-out only & Limited access \\
\hline Massachusetts & 24-Mar & 18-May & Not encouraged & 10-person limit & $\begin{array}{c}\text { With } \\
\text { limitations }\end{array}$ & Yes & Dine-out only & Limited access \\
\hline Michigan & 24-Mar & 1-Jun & $\begin{array}{c}\text { Essential needs/work } \\
\text { only }\end{array}$ & Prohibited & $\begin{array}{c}\text { With } \\
\text { limitations }\end{array}$ & No directive & Dine-out only & Yes \\
\hline Minnesota & 27-Mar & 17-May & Not encouraged & 10-person limit & $\begin{array}{c}\text { With } \\
\text { limitations }\end{array}$ & No directive & Dine-out only & Yes \\
\hline Mississippi & 3-Apr & 27-Apr & Not encouraged & 10-person limit & $\begin{array}{c}\text { With } \\
\text { limitations }\end{array}$ & No directive & Yes & Yes \\
\hline Missouri & 6-Apr & 3-May & Not encouraged & Yes & Yes & No directive & Yes & Yes \\
\hline Montana & 28-Mar & 26-Apr & $\mathrm{OK}$ & 10-person limit & $\begin{array}{c}\text { With } \\
\text { limitations }\end{array}$ & Yes & Yes & Yes \\
\hline Nebraska & None & None & No order & 10-person limit & $\begin{array}{c}\text { With } \\
\text { limitations }\end{array}$ & No directive & Yes & Yes \\
\hline Nevada & 1-Apr & 15-May & Not encouraged & 9-person limit & $\begin{array}{c}\text { With } \\
\text { limitations }\end{array}$ & No directive & With restrictions & Limited access \\
\hline $\begin{array}{c}\text { New } \\
\text { Hampshire }\end{array}$ & 27-Mar & 15-Jun & $\begin{array}{c}\text { Essential needs/work } \\
\text { only }\end{array}$ & 9-person limit & $\begin{array}{c}\text { With } \\
\text { limitations }\end{array}$ & No directive & $\begin{array}{l}\text { Dine-out and } \\
\text { outdoor only }\end{array}$ & Yes \\
\hline New Jersey & 24-Mar & 9-Jun & $\begin{array}{l}\text { Essential needs/work } \\
\text { only }\end{array}$ & 10-person limit & $\begin{array}{c}\text { With } \\
\text { limitations }\end{array}$ & No directive & Dine-out only & Limited access \\
\hline New Mexico & 24-Mar & 28-Aug & $\begin{array}{c}\text { Essential needs/work } \\
\text { only }\end{array}$ & 5-person limit & $\begin{array}{c}\text { With } \\
\text { limitations }\end{array}$ & Yes & Dine-out only & Limited access \\
\hline New York & 22-Mar & 27-Jun & Not encouraged & Prohibited & $\begin{array}{c}\text { With } \\
\text { limitations }\end{array}$ & No & Dine-out only & Limited access \\
\hline North Carolina & 30-Mar & 22-May & With limitations & 10-person limit & $\begin{array}{c}\text { With } \\
\text { limitations }\end{array}$ & No directive & Dine-out only & Limited access \\
\hline
\end{tabular}




\begin{tabular}{|c|c|c|c|c|c|c|c|c|}
\hline North Dakota & None & None & No order & No directive & Yes & For visitors & Yes & Yes \\
\hline Ohio & 23-Mar & 19-May & $\begin{array}{l}\text { Essential needs/work } \\
\text { only }\end{array}$ & 10-person limit & $\begin{array}{c}\text { With } \\
\text { limitations }\end{array}$ & For visitors & Yes & Yes \\
\hline Oklahoma & 28-Mar & 6-May & $\mathrm{OK}$ & Yes & $\begin{array}{c}\text { With } \\
\text { limitations }\end{array}$ & Yes & Yes & Yes \\
\hline Oregon & 23-Mar & 19-Jun & $\begin{array}{l}\text { Essential needs/work } \\
\text { only }\end{array}$ & 25-person limit & No & No directive & Dine-out only & Limited access \\
\hline Pennsylvania & 1-Apr & 4-Jun & $\begin{array}{l}\text { Essential needs/work } \\
\text { only }\end{array}$ & 25-person limit & $\begin{array}{c}\text { With } \\
\text { limitations }\end{array}$ & No directive & Dine-out only & Limited access \\
\hline Rhode Island & 28-Mar & 8-May & $\mathrm{OK}$ & 5-person limit & $\begin{array}{c}\text { With } \\
\text { limitations }\end{array}$ & For visitors & Dine-out only & Limited access \\
\hline South Carolina & 6-Apr & 4-May & Not encouraged & 2-person limit & $\begin{array}{c}\text { With } \\
\text { limitations }\end{array}$ & No directive & With restrictions & Limited access \\
\hline South Dakota & None & None & $\mathrm{OK}$ & No directive & Yes & No directive & With restrictions & No directive \\
\hline Tennessee & 31-Mar & 30-Apr & Not encouraged & 10-person limit & $\begin{array}{c}\text { With } \\
\text { limitations }\end{array}$ & No directive & $\begin{array}{c}\text { Yes, at } 50 \% \\
\text { capacity }\end{array}$ & Limited access \\
\hline Texas & 2-Apr & 30-Apr & Ok & Not encouraged & $\begin{array}{c}\text { With } \\
\text { limitations }\end{array}$ & Yes & Yes & Limited access \\
\hline Utah & 27-Mar & 1-May & $\mathrm{OK}$ & 20-person limit & $\begin{array}{c}\text { With } \\
\text { limitations }\end{array}$ & Yes & Yes & Yes \\
\hline Vermont & 25-Mar & 15-May & Not encouraged & 10-person limit & $\begin{array}{c}\text { With } \\
\text { limitations }\end{array}$ & Yes & Dine-out only & Limited access \\
\hline Virginia & 30-Mar & 10-Jun & $\begin{array}{l}\text { Essential needs/work } \\
\text { only }\end{array}$ & 10-person limit & $\begin{array}{c}\text { With } \\
\text { limitations }\end{array}$ & No directive & $\begin{array}{l}\text { Dine-out and } \\
\text { outdoor only }\end{array}$ & Limited access \\
\hline Washington & 23-Mar & 31-May & $\begin{array}{l}\text { Essential needs/work } \\
\text { only }\end{array}$ & Prohibited & $\begin{array}{c}\text { With } \\
\text { limitations }\end{array}$ & No directive & Dine-out & Limited access \\
\hline West Virginia & 24-Mar & 4-May & Not encouraged & 25-person limit & $\begin{array}{c}\text { With } \\
\text { limitations }\end{array}$ & Yes & Outdoor only & Limited access \\
\hline Wisconsin & 25-Mar & 13-May & Ok & No directive & Yes & No & Yes & Yes \\
\hline Wyoming & 28-Mar & 30-Apr & No order & 9-person limit & $\begin{array}{c}\text { With } \\
\text { limitations }\end{array}$ & Yes & Dine-out only & Limited access \\
\hline $\begin{array}{l}\text { District of } \\
\text { Columbia }\end{array}$ & 1-Apr & 15-May & $\begin{array}{l}\text { Essential needs/work } \\
\text { only }\end{array}$ & 10-person limit & No & No directive & Dine-out only & No \\
\hline
\end{tabular}

(Source: Adapted from Wu et al., 2020; Gershman, 2020; and Ballotpedia, 2020) 


\section{Coronavirus Impacts on Travel Behavior and Activity Engagement}

The global pandemic and its associated social distancing measures have affected daily travel patterns, including the number and types of out-of-home activities (De Vos, 2020). A recent study by Streetlight Data shows a drastic drop in vehicle travel across the U.S. by 68 to 72 percent in the last two weeks of March 2020 and the first week of April, compared with the first week of March (Dutzik, 2020). Normal activities, such as routine doctor's visits, hair styling, dog grooming, routine trips to the store, workplace, and restaurants have been altered during these early weeks of this national crisis (Dutzik, 2020; JPMorgan Chase \& Co., 2020). Most importantly, people have tended to suspend short and unnecessary driving and trips to the store or other locations during the unprecedented crisis (Wilson, 2020).

Analysis of a sample of about 2,500 respondents from the Netherlands Mobility Panel showed that the COVID-19 outbreak has the potential to result in structural changes in travel behavior and activity engagement. Based on the research findings, about 80 percent of people reduced their out-of-home activities; the percentage was higher among older adults. Compared to the same period last year, the number of trips decreased by 55 percent, and distance traveled dropped by 68 percent (de Haas et al., 2020).

Since the onset of COVID-19, several public transportation modes/options have been perceived by some as "unsafe" due to challenges with social distancing including buses and airplanes. For example, the crisis led to 50 to 90 percent declines in transit ridership in major metropolitan areas based on reports from transportation apps, such as Transit App, Moovit, and Google (Taylor and Wasserman, 2020). About 72 percent (7 of 10 respondents) of participants surveyed in a sample of 1,000 New York State residents confirmed that they would be unlikely to use public transportation (e.g., plane, train, bus, or cruise ship) over private vehicles even after social distancing restrictions are removed later this year (Taylor, 2020). Conversely, a few researchers anticipated that low-income households that are economically impacted by the crisis, will likely switch to public transportation during the pandemic restrictions (Taylor and Wasserman, 2020). Considering recommendations from the Centers for Disease Control (CDC) that seem to discourage the use of public transportation during the pandemic, it may be more challenging to promote transit in the near future for choice riders (Blanco, 2020; Premack, 2020). These recommendations could also exacerbate inequity, especially in view of transit dependent communities.

As with many other sectors, the COVID-19 pandemic has significantly affected transportation network companies (TNCs), such as Uber, Lyft, and Dallas-based Alto. For example, Alto experienced a 90 percent decline in ridership from February to March 2020. Similarly, Lyft rides decreased by 70 percent in April 2020 compared to 2019. After reopening in May 2020, ridesharing demand increased by 300 percent compared to April for Alto (although it is still down 80 percent from where it was pre-COVID-19) and Lyft rides increased by 26 percent (Walters, 2020). 
Like other shared mobility systems, taxi companies, already struggling due to emerging ride-hailing services, have been significantly impacted by the global outbreak. Limited airline flights and fewer people outside have also contributed to taxi companies' struggles during the pandemic. Some taxi drivers have mentioned sleeping at airports to survive and earn the bare minimum during the crisis (Rivoli, 2020). The risks associated with riding a taxi versus an Uber or Lyft may depend on the safety and sanitization policies of the various companies.

Taxi fleet vehicles are more likely to have plexiglass barriers that can facilitate distancing between drivers and riders than privately owned ride-hailing vehicles. Taxi companies may also be able to closely monitor more centralized cleaning and sanitization of vehicles than ridehailing organizations. Conversely, ride-hailing service providers can have access to real-time feedback from customers on how to improve services during the crisis compared to taxi companies (Bologna, 2020). The car rental sector has also been impacted by the COVID-19 crisis. For example, the outbreak has pushed companies like Hertz, Avis, and Advantage to file for bankruptcy protection in May, and rental car rates in general decreased by up to 60 percent (12 to 16 dollars a day plus taxes) compared to pre-pandemic rates (Thompson, 2020). The car rental market depends mostly on domestic and international flights; therefore, fewer flights means less car renting.

The novel coronavirus has also plummeted micromobility industries with 50 to 60 percent declines in the number of passenger-kilometers traveled worldwide (Heineke et al., 2020). For example, e-scooter ridership dropped considerably in some areas during the outbreak. For example, in Oregon, ridership decreased from 12,320 scooter trips on February 24, 2020 to 4,029 total trips around March 16, and to 138 e-scooter trips at the end of March. A reason for these declines may be linked to perceptions of the risk of infection. As a result, micromobility companies (e.g., Lime and Spin) have adopted safety measures to reduce the spread of the virus (Ferenchik, 2020; Theen, 2020, Lyft, 2020; Naka, 2020). On the other hand, micromobility has developed into a lifeline during the pandemic for residents with limited transportation options, especially for those people who were not comfortable using mass transit (Naka, 2020).

During this global phenomenon, telework and virtual services have emerged to be the current reality. Some people have also adopted walking and biking as an approach to relax, fight stress, and promote overall well-being (De Vos, 2020; Dutzik, 2020). About 44 percent of workers from the Netherlands Mobility Panel study switched to teleworking, worked more hours from home, or held 30 percent more meetings online (de Haas et al., 2020).

After the pandemic, approximately 90 percent of people anticipate increases in out-ofhome activities and 27 percent of workers plan to continue working from home. Regarding air travel, 20 percent of people will avoid flying post-COVID-19 (de Haas et al., 2020). Additionally, major destinations may change as social distancing restrictions are removed. Upstate New Yorkers plan to avoid crowds (58 percent), travel locally (56 percent), and avoid flights (54 percent) after the crisis. Study participants from New York State also indicated the top 
three destinations after social-distancing orders are removed to be state parks ( 54 percent), lakes (48 percent), and shopping (41 percent) (Taylor, 2020).

Similarly, CarGurus surveyed 722 U.S. car buyers in April 2020 and found out that 39 percent of participants (who previously used the service) would avoid or stop using ride-sharing services post pandemic, while 18 percent would increase their use of the apps, and 43 percent would not change the way they used them before the outbreak (Beedham, 2020). Additionally, a study confirmed that travel decisions might differ by generations after the COVID-19 pandemic. Findings from the study showed that Gen $\mathrm{Z}$ is more likely to travel once restrictions are relaxed than older generations (Taylor, 2020). The age characteristics of shared micromobility users are also likely to remain similar post pandemic. Half of the shared micromobility users are anticipated to remain below 34 years old after the crisis (Naka, 2020).

Nevertheless, the long-term effects of the outbreak on vehicle travel and travel behavior remain uncertain (Dutzik, 2020). The future of shared mobility systems depends on several factors, including the use of effective strategies to regain loyalties of customers. Despite the challenges and uncertainties, the pandemic presents an opportunity to restore public transportation safety, accelerate the adoption of electric vehicles for a clean and healthy environment, and expand access to bike-sharing and other micromobility options to reduce resurgence of traffic, crashes, and pollution (Dutzik, 2020).

\section{ICT and Travel Behavior (COVID-19 Impacts)}

ICT has played an important role in improving the quality and security of transportation systems and services. Intelligent transportation systems (ITS), a type of ICT frequently used in the transportation sector, is based on the integration of computer, electronics, communication technologies, and management strategies. ITS supports the efficiency and safety of transportation systems and enables an environment suitable for communication and interaction between vehicles, drivers, passengers, road operators, and managers (Annur \& Ponnusamy, 2020).

Real-time information, accessible through ICT, has also revolutionized the travel landscape and improved the travel experience of many individuals. An example of how real-time information is used to enhance shared mobility systems is bus tracking, which enables passengers to track buses and to know the estimated bus arrival times. Real-time information is proved to increase transit ridership, decrease wait and travel times, and enhance travel planning (Bruglieri et al., 2015; Watkins, 2011).

The relation between ICT, time use, and energy requirements was also explored in past research. For example, ICT improves access to opportunities, affects time and space constraints, activity participation, duration, and planning (Bieser and Hilty, 2020). Although ICT has many other benefits, including enabling virtual mobility and reducing needs for travel, it can also lead to more trips based on information available on the Internet and is often related to long-distance driving and greenhouse gas emissions (Cerqueira et al., 2020), which could counter some benefits of shared mobility systems. Additionally, the development of ICT has enabled the use of 
spatial and open data to understand travel behavior. Ridership, arrivals, departures, and other system information, like in bike-sharing, could now be easily collected because of ICT. With ICT, data can also be collected at different temporal scales from many diverse locations simultaneously (Durán-Rodas et al., 2020).

Lastly, household socioeconomic characteristics, individual personal characteristics, activity participation, travel behavior, and time allocation patterns influence how ICT is used (Varghese and Jana, 2019; Ryu et al., 2020). For example, the needs for real-time information vary by population groups. (Tang et al., 2020). The two main ways ICT impacts our transportation systems are briefly summarized next and is followed by a short section that covers the impact of COVID-19 on ICT.

\section{Telecommunication and E-Commerce}

Telecommunication includes the use of ICT long considered as an excellent opportunity to impact the transportation system. The impact of telework on reducing travel demand, decreasing congestion, and increasing the use of active transportation modes has been demonstrated in several studies. These findings sometimes have conflicted when evaluating full-time and parttime teleworkers (Elldér, 2020). Additionally, studies demonstrated that telecommuting could generate unsustainable non-work travel by increasing vehicle mileage, car dependency, and physical inactivity in areas with isolated destinations. Other researchers argued that this relationship might be contingent on the number and types of non-work trips and the availability of various services and amenities near the telecommuters. Although telecommuting has had the potential to lead to fewer commuter trips, it has occasionally created more non-work trips with other purposes (Budnitz et al., 2020). E-commerce is another field that has been considered by transportation professionals and researchers when assessing the impact of ICT on travel behavior. Several studies have focused on assessing the effects of e-commerce on shopping trips. Some of the findings proved that traditional shopping trips were occurring despite the availability of ICT (Pernot, 2020).

\section{Smartphones and Ride-Hailing}

ICT and smartphones have supported the use of ride-hailing services (Fu, 2020; Sabouri et al., 2020). These services have influenced household travel behavior, mobility patterns, and car ownership decisions (Acheampong et al., 2020; Sabouri et al., 2020). Some researchers have shown that the choice of ride-hailing services depends on ease, socio-demographic factors, perceived advantages, safety risks, and car-dependent lifestyles. Ride-hailing services are employed for several purposes, including special occasions, work, and school.

The decrease in travel time and single passenger occupancy are other reasons why ridehailing services are chosen in suburban settings. Ride-hailing services often substitute for various other modes, including conventional taxis, public transportation, private vehicles, and walking. Prior to the crisis, ride-hailing service users have usually used the services in combination with other modes. During the pandemic, this pattern has changed. The ride-hailing services have 
mainly been used for full door-to-door trips, instead of assisting with first and last mile access (Acheampong et al., 2020).

In addition to ride-hailing, smartphones have increasingly been utilized for travel decisions. For example, smartphones have provided opportunities for virtual activities, including e-commute, e-commerce, e-governance (Jamal and Habib, 2020). Age and attitudes have been found to affect smartphone use for travel planning and outcomes. Some researchers concluded that millennials had used smartphones to plan their trips and concluded that they are effectively using them for travel (Jamal and Habib, 2020). The frequency of daily smartphone usage has been related to increased total trips and active traveling for older adults ( $\geq 65$ years) more than young and middle-aged groups (18-64 years) (Yang et al., 2020).

\section{ICT and COVID-19}

ICT had increasingly revolutionized the transportation industry pre-pandemic and has been crucial during the COVID-19 outbreak. Several services were enabled by ICT during the COVID-19 era, including telework, video conferencing, telemedicine, food delivery, online purchases, remote learning, and entertainment. Examples of the use of ICT in the transportation sector during the outbreak include using digital messaging solutions to protect riders and drivers with customized rider messaging, such as the ones illustrated in Figure 7 (Mass Transit, 2020). Using autonomous vehicles and robot taxis to deliver COVID-19 test samples, groceries, and medicines, as well as to facilitate social distancing are also topics under discussion.

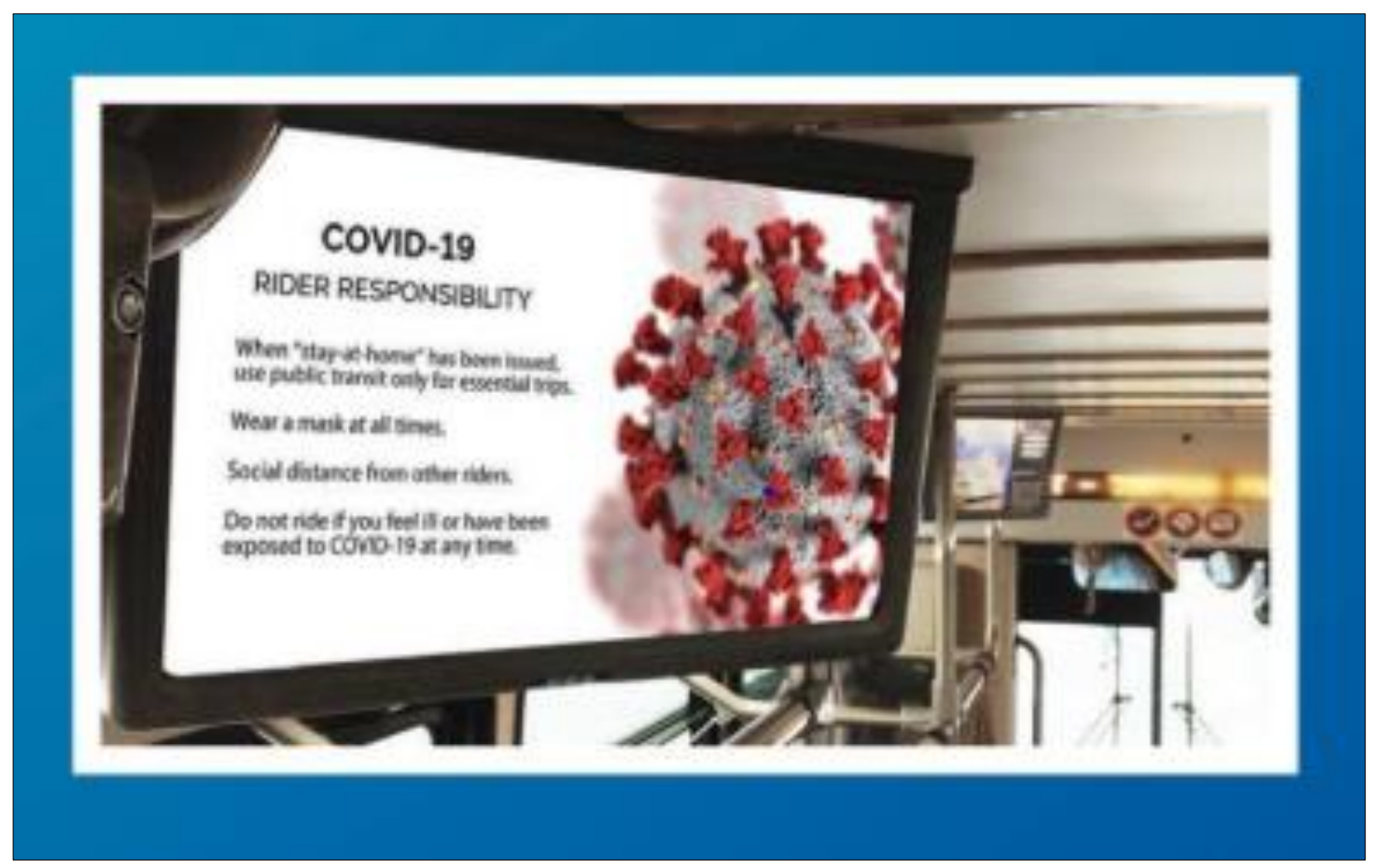

Figure 7. Digital Messaging Solutions to Protect Passengers and Drivers (Source: Mass Transit, 2020) 
Although ICT has been beneficial during the crisis, it can bring other challenges related to identity protection, security management, network evolution, services penetration, and application usage (Wood, 2020). Additional challenges raised with the increasing use of ICT comprise widening equity and accessibility gaps. For example, ICT is not accessible by all social groups because it often requires access to a smartphone and Internet; therefore, reliance on its use during the COVID-19 crisis has reinforced inequity and amplified the gap between socioeconomic groups (Wood, 2020). Besides those challenges, many ICT applications have been disrupted during the pandemic, including airports and supply chains, among others.

\section{Shared Mobility System Strategies during COVID-19 Era}

The pandemic has led to disruptions in daily businesses of shared mobility companies/providers. This section of the report describes and synthesizes the various strategies employed by shared mobility systems in response to the COVID-19 global crisis.

\section{Public Transportation Agency Strategies}

Public transportation is essential to our communities. A recent article summarized how several cities around the world had used shared mobility in innovative ways to address the changing needs of their communities during the COVID-19 global crisis, especially for essential service workers like grocery store employees, delivery people, first responders, and healthcare workers (Cooperman, 2020). These workers often require public transportation to get to work during the pandemic. Some of the strategies used include:

- Repurposing public transportation for essential healthcare workers by expanding service zones to hospitals and largest medical centers.

- Using surplus vehicles and drivers to serve critical locations like hospitals, grocery stores, food banks and other critical transportation using newly launched app.

- Rapidly making changes to on-demand public transportation network to focus its service more effectively on essential employees and to minimize person-to-person contact.

- Launching new on-demand micro-transit service to healthcare and enabling door-to-door on-demand free rides to and from local healthcare facilities

- Supporting essential travel needs during the COVID-19 pandemic, including first-andlast-mile services, that would extend access to affordable, efficient, and convenient public transit, and services to support residents and essential workers during the health crisis. For example, under normal operations, the services serve major bus stops and transit centers. However, during ongoing emergency response in the community, selected essential service locations, including pharmacies, grocery stores and health clinics, are added to ensure efficient access to these critical services.

- Allowing grocery stores and small businesses to deliver goods through apps, pooling multiple deliveries into the same vehicle to increase efficiencies, and providing drivers with the ability to distinguish between deliveries and passenger rides. 
- Altering hours of operation to better align with medical shifts and capped all vehicles at 50 percent capacity.

- Quickly adjusting service plans to limit transportation to essential trips in a first-and-last mile model (addressing gaps in transit networks in the area).

- Providing riders with private rides to properly account for social distancing.

Other strategies under consideration by public transportation agencies include anti-microbial film protection placed inside and outside of transit vehicles to protect frequently touched areas (e.g., grab bars, handrails, digital screens, elevator buttons) from bacteria and virus. This form of protection provides a 24x7 defense against infections (see Figure 8) (Mass Transit, 2020). This particular strategy could also be adapted to be used to help protect users of other shared mobility systems.
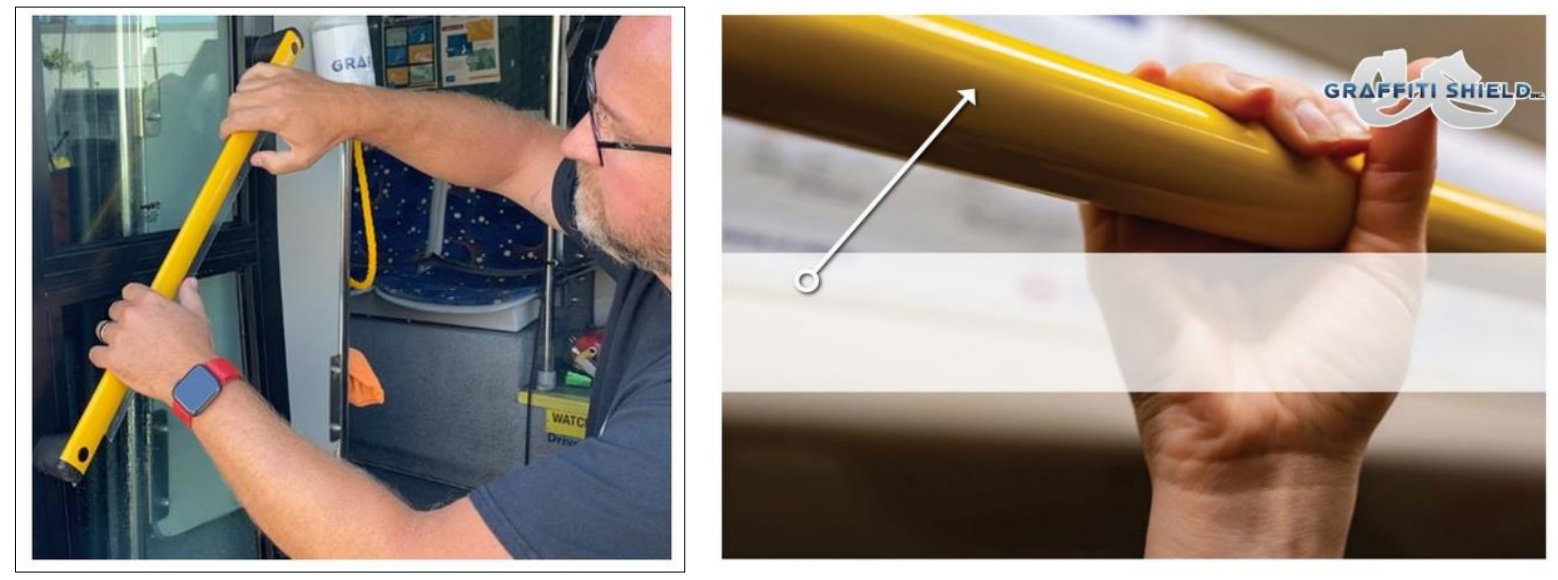

Figure 8. Anti-Microbial Film Protection to Protect Frequently Touched Areas (Source: Mass Transit, 2020)

Northwestern University Transportation Center (NUTC, 2020, July) hosted online round table discussions (webcasts) aimed to provide strategies used or considered by some public transportation agencies in the U.S. and across the world. The sections below describe the strategies for each of these participating agencies.

Chicago Transit Agency (CTA) (Chicago, IL)

The CTA is one of the largest public transportation agencies in the United States and has been dramatically affected by the crisis. The effects are evidenced by an 80 percent decrease in ridership, which includes a much higher drop for bus systems than rail systems (NUTC, 2020). Despite the decrease in ridership, CTA maintained its pre-COVID-19 service level during the global outbreak to serve the needs of essential workers.

This consistency was important for some minority communities in Chicago that had very significant ridership levels during the crisis compared to their counterparts. The company explained that the CTA workforce consisted of a major share of African American workers 
(some with underlying health conditions), and at least seven CTA employees had died during the aftermath of the COVID-19 outbreak. CTA believes that innovation, flexibility, and transparency are major dimensions that can help in the recovery process. Learning and adapting from other transit agency best practices, continually revisiting decisions, integrating CTA services with other services including ridesharing and bikesharing can help during and after the outbreak (NUTC, 2020). Some of the strategies adopted (or considered) by CTA in response to the COVID-19 crisis include (NUTC, 2020; CTA, 2020):

- Doubling or tripling cleaning crew

- Providing hand sanitizer dispensers at stations

- Using ventilation in buses

- Employing electrostatic sprayers for deeper cleaning: CTA is currently using new e-Mist devices that apply cleaning solution as a mist to provide for more thorough coverage. Machines supplement existing deep-cleaning measures and allow more efficiently and thoroughly cleaning of vehicles (see Figure 9).

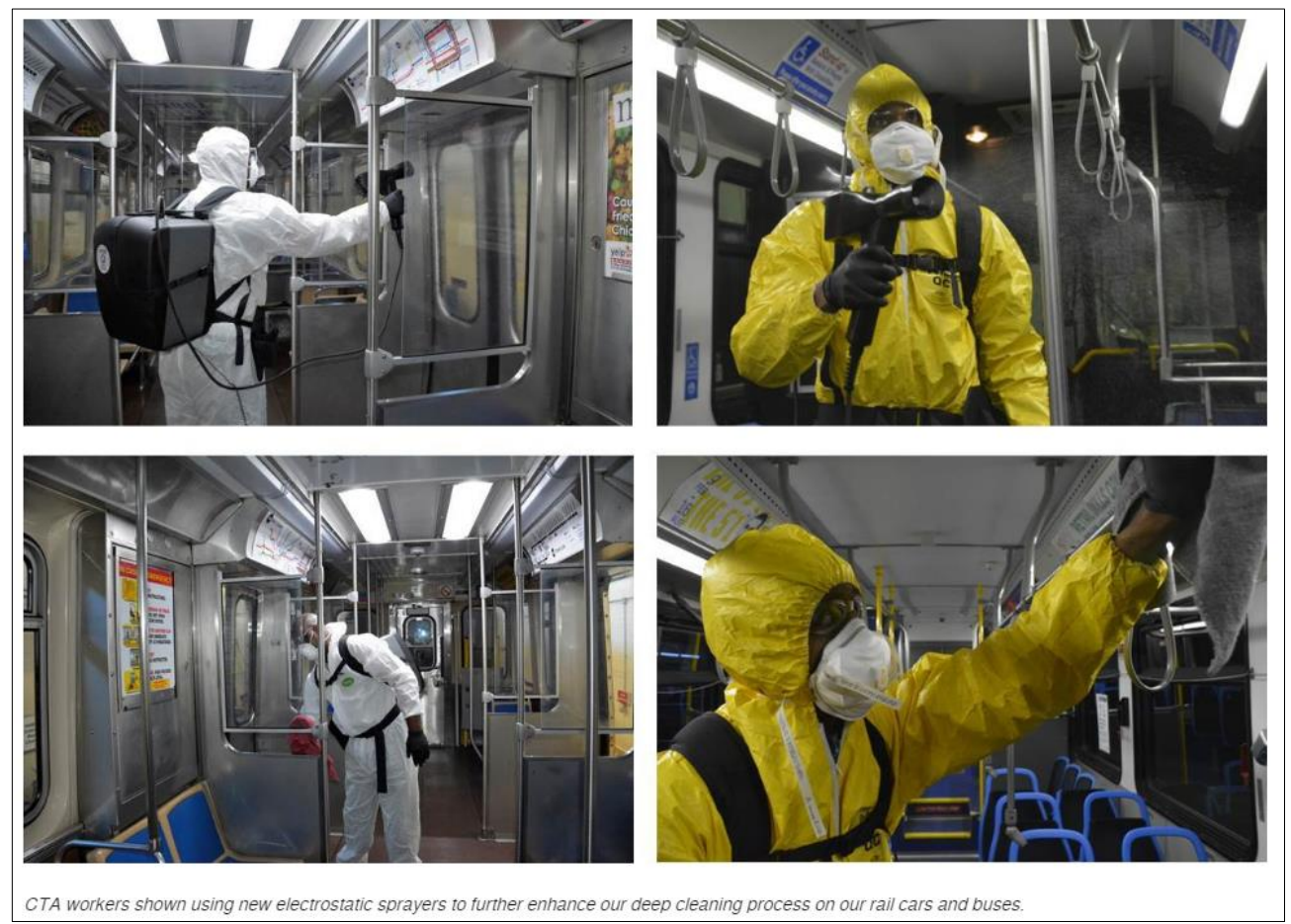

Figure 9. CTA Electrostatic Sprayers for Deep Cleaning (Source: CTA, 2020)

- Testing anti-microbial surface coating: CTA is testing new anti-microbial surface coating products on the interior of vehicles that prevent certain materials (e.g. bacteria, viruses, liquids, etc.) from sticking to treated surfaces for an extended period of time.

- Applying ultraviolet UV cleaning technology: CTA is also investigating UV light cleaning, currently being pilot tested by New York City. 
- Using contactless payment methods

- Practicing rear-door boarding

- Using bus crowding management strategies, including using the guideline of 15 or more passengers on a standard $40 \mathrm{ft}$ bus, 22 or more passengers on a $60 \mathrm{ft}$ articulated bus

- Educating customers about the crisis

- Developing a new ridership information dashboard that provides real-time demand information, to enable good transit trip decision making process (see Figure 10):

- The new Ridership Information Dashboard helps with trip planning and to avoid traveling during heavy ridership periods. A color-coding system (Green, Yellow and Orange) is used to depict possible space availability for each bus route by hour based on the average, historic ridership during COVID-19 compared with the established capacity limits (i.e. 15 customers on a standard 40-foot bus, and 22 customers on a 60-foot articulated bus and each rail car).

- Updated weekly, the bus crowding report shows general capacity levels, based on prior two weeks of ridership, for each hour of the day-helping customers determine the best times for their travel, especially customers who may have more flexibility on when to ride, and to help promote social distancing.

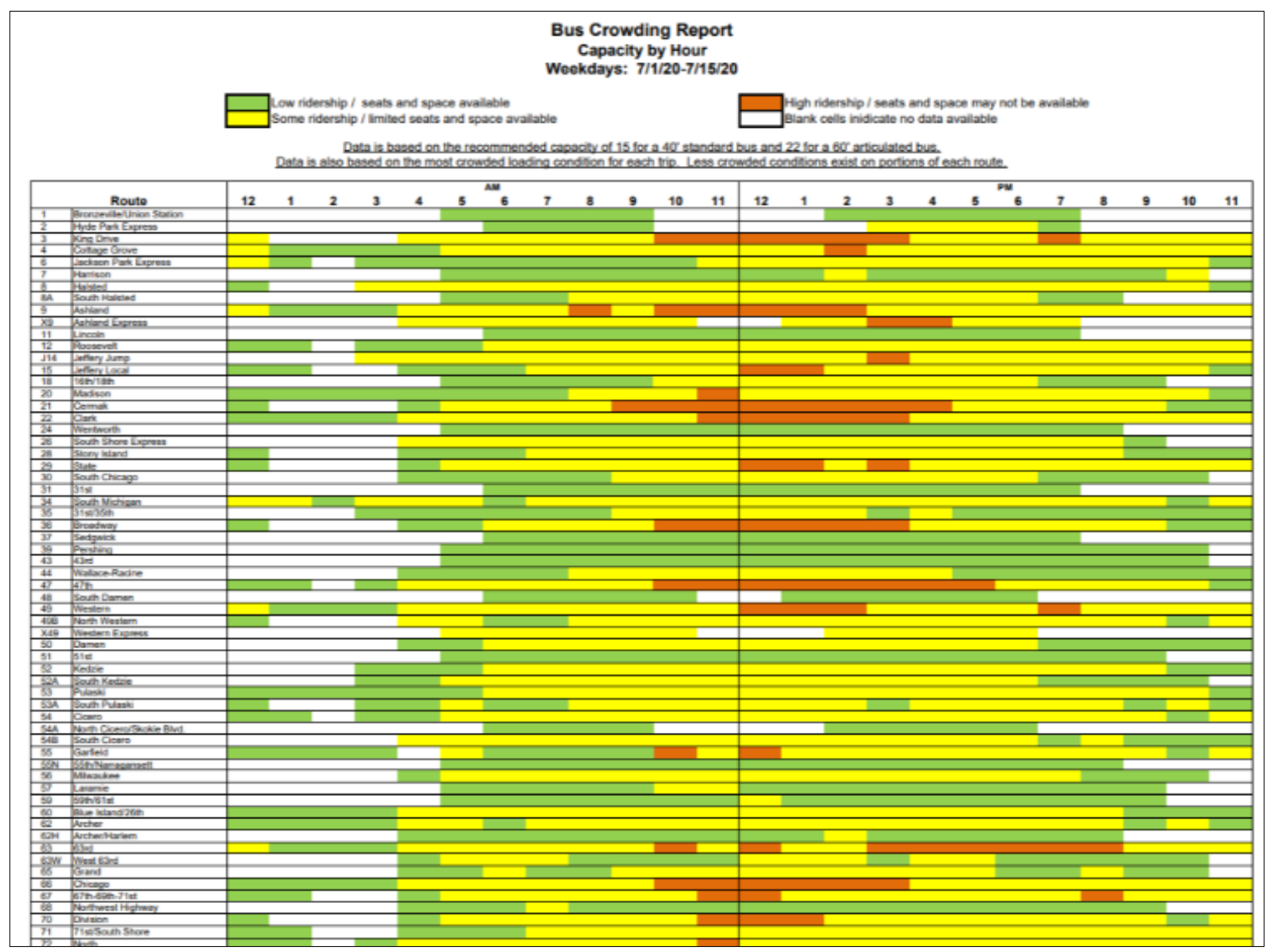

Figure 10. CTA Ridership Information Dashboard

(Source: CTA, 2020) 
- Using messaging and customer feedback and behavior to make adjustment

- Allowing staggering work hours for employees

- Collaborating with Chicago Department of Transportation (CDOT) for alternative services

- Moving services around instead of adding more services to adjust capacity constraints. For example, for routes with higher ridership levels, either deploying longer, $60 \mathrm{ft}$ buses or increasing headways to provide sufficient capacity.

- Placing new system signage, such as new circular floor decals at some stations that urge social distancing. The new decals, which feature the message, "Be safe! Make a space!" in both English and Spanish, are evenly spaced along all platforms, throughout stationhouses near Ventra vending machines and in elevators. CTA is also expanding signage at stations and in vehicles urging the use of masks when taking public transit (see Figure 11).

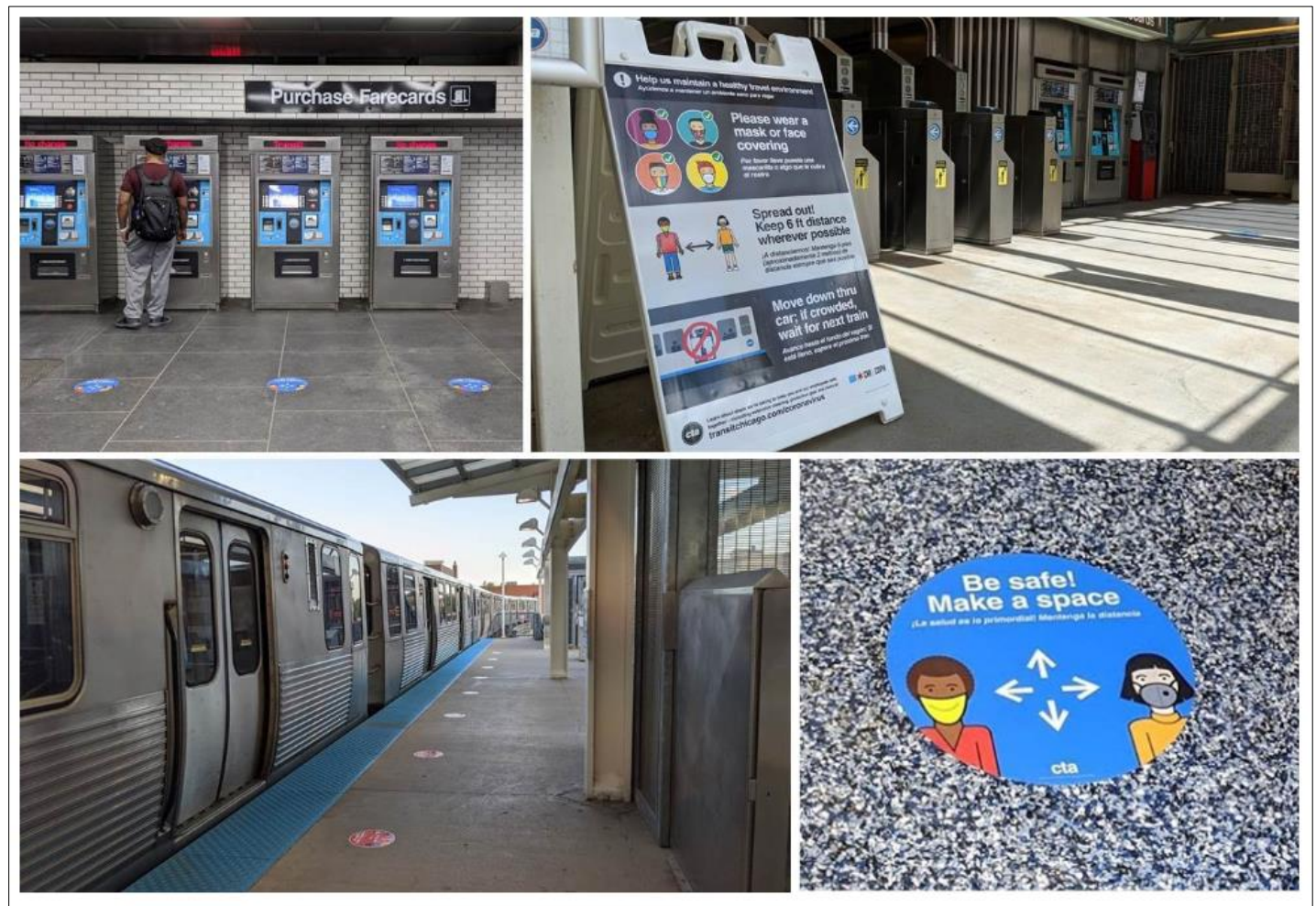

Figure 11. New Coronavirus Signages - CTA

(Source: CTA, 2020)

- Providing free "Travel Healthy" kits at some locations to welcome riders back - the kit contained a reusable cloth mask, a $2 \mathrm{oz}$. bottle of hand sanitizer and a healthy riding tips guide (see Figure 12 for details). 


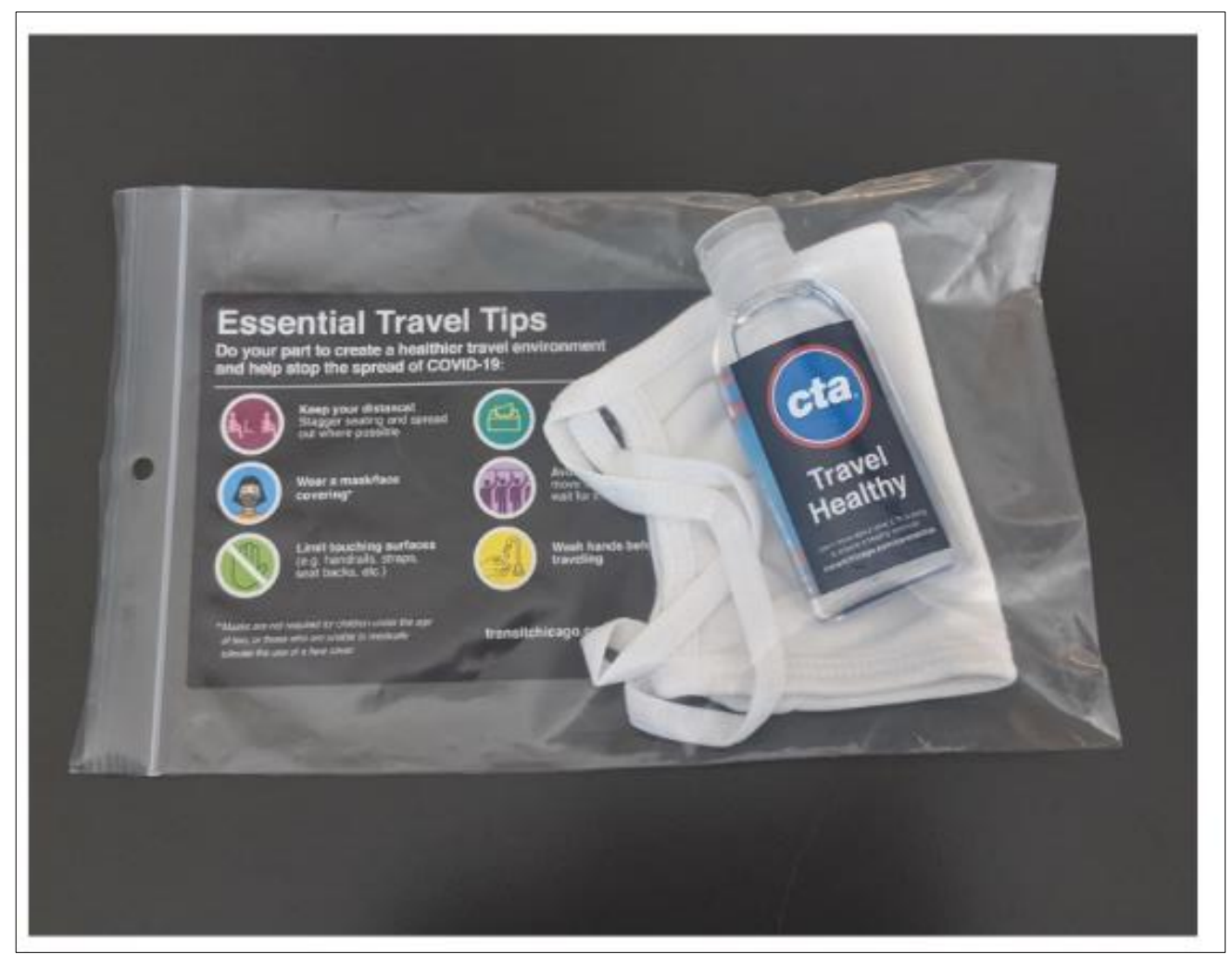

Figure 12. CTA Travel Healthy Kits

(Source: CTA, 2020)

\section{Washington Metropolitan Area Transit Authority (WMATA) (Washington D.C.)}

WMATA or Metro is a transit agency that operates in the Washington metropolitan area. A quarter of the WMATA workforce has been exposed to the COVID-19 virus (NUTC, 2020). WMATA closed many low ridership stations and has reduced service hours (WMATA, 2020). Like CTA, WMATA also contends that it will be useful to learn from peer agencies across the globe that reopened before the United States. The agency believes that transit will be crucial for sustainable and environmentally friendly cities in a post-COVID world. Over the longer term, WMATA sees collaborating with transportation network companies (TNCs) and agencies as vital (NUTC, 2020).

Specific strategies by WMATA include (NUTC, 2020; WMATA, 2020):

- Sanitizing the vehicles and facilities (see Figure 13)

- Requiring face coverings on Metro trains, buses, and in stations

- Closing first and last cars of all trains

- Placing available seats for customers 6 feet apart in transit vehicles, which reduced capacity to 25

- Implementing rear-door boarding systemwide

- Blocking area in front of the bus

- Reallocating bus service to address crowding 
- Conducting surveys and focus groups to get customer input

- Working with partners to obtain real-time information

- Developing an online dashboard to serve as a clearinghouse of information regarding confirmed employee cases

- Splitting workforce into multiple groups to enable social distancing and reduce potential contagion spread.

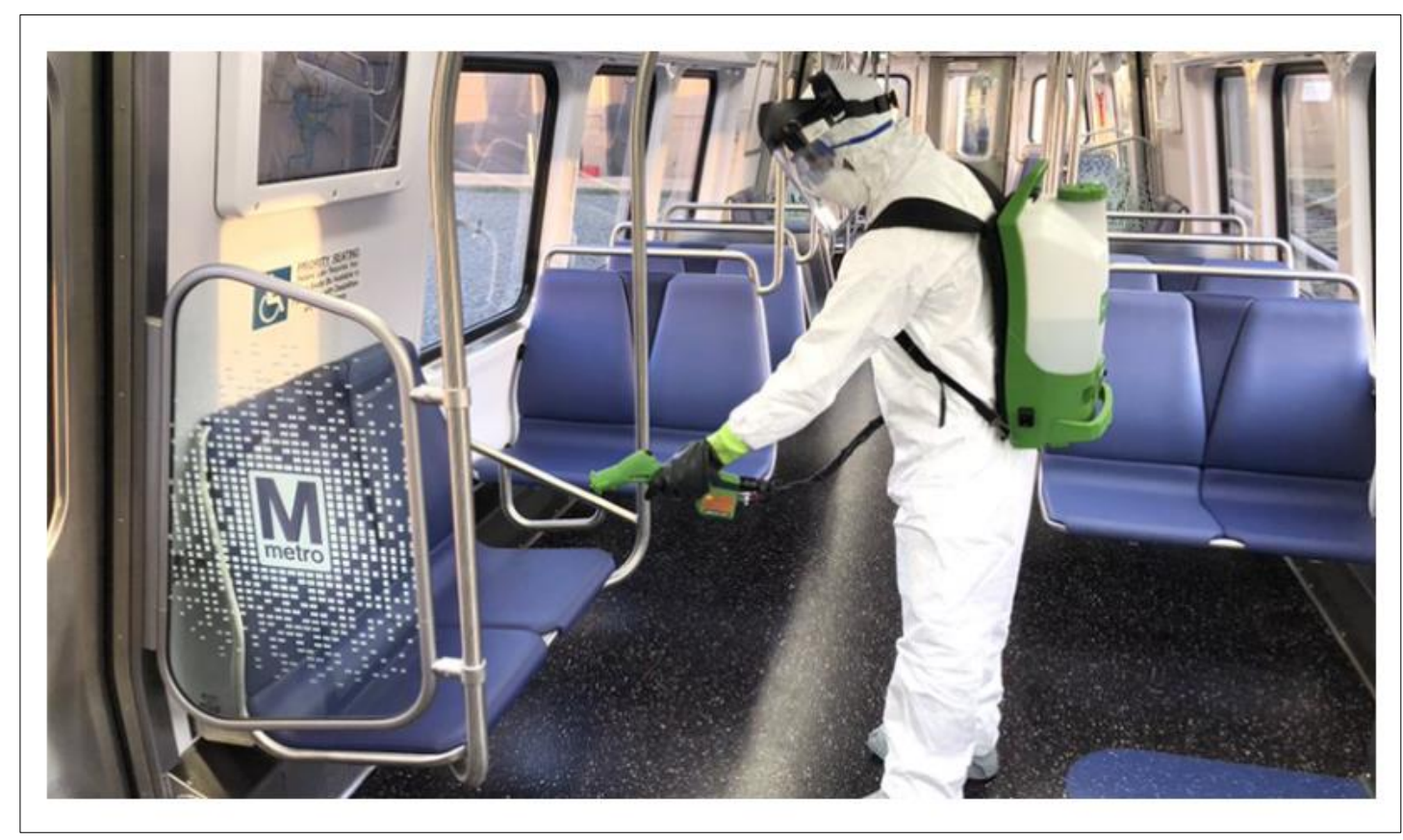

Figure 13. WMATA Cleaning Process

(Source: WMATA, 2020)

\section{Jacksonville Transportation Authority (Jacksonville, Florida)}

JTA is in charge of providing transit services in the city of Jacksonville, Florida. In the aftermath of the coronavirus, JTA service levels dropped by 75 percent which pushed the agency to reduce service and modify schedules (NUTC, 2020). Fortunately, even before the pandemic enforced changes, JTA had installed plexiglass shields in place for bus operators. Additionally, JTA employees were also provided with personal protective equipment (PPE). An important step taken by JTA during the crisis was to delay the opening of the regional transit center and redesign the new facility to support healthy sanitation and social distancing measures.

Scheduling has been the biggest challenge faced by JTA during the outbreak. JTA believes that embracing emerging technologies such as autonomous vehicles will be essential to mitigate risks during similar pandemics. JTA also highlighted during the discussion that good leadership was a much more important cog during a pandemic era. Some strategies used by JTA in response to the crisis include (NUTC, 2020; JRTC, 2020):

- Enhanced cleaning of facilities and vehicles several times a day 
- Requiring face coverings on-board their fleet

- Enforcing the mandated $6 \mathrm{ft}$ social distancing by closing off seats. As a consequence of this, bus capacities have been limited to 20

- Adding extra buses to make up for capacity reduction.

- Splitting working schedules into A and B groups.

- Daily temperature checks for employees reporting to work.

- Using Business Intelligent Unit systems to help pinpoint where extra buses are needed with focus on serving the transit dependent communities

- Identify time and locations of transit issues during the crisis for safer and on-time system performance

- Some other strategies employed include engaging with peer agencies on best practices and knowledge transfer, talking to industry leaders using online meeting platforms, receiving feedback from social media platforms, developing an application that enables customers to directly reach JTA safety staff, and collaborating with the city leadership across all spheres (e.g., financial, legal, and political) in order to addressing community needs.

\section{Vancouver Transportation Authority (TransLink) (Vancouver, Canada)}

TransLink provides services in Metro Vancouver, Canada. Based on the insights from the webinar, TransLink has experienced a fifty percent reduction in revenue and is at a thirty percent pre-COVID-19 ridership since the onset of the pandemic (NUTC, 2020). Though the agency states that the health and safety of their 4,000 bus operators was the number one priority, a third of TransLink customers do not use face coverings since masks have not been mandatory in Vancouver. This ruling may change as more places reopen, and buses become crowded; although, alternative working schedules are likely to continue in the immediate future. TransLink also purports that sharing information and learning about best practices is invaluable during this critical time (NUTC, 2020).

TransLink expects to regain about 70 percent of its ridership by next year though the regrowth will likely depend on people's willingness to use transit, teleworking trends, and their acceptance of the available fare structure. The Vancouver-based agency advises careful fare system management, proposes contactless payment methods, and may add cashless payments in the future. TransLink believes that this pandemic could be used to explore implementing bus priority systems, like dedicated lanes for buses, similar to other cities that are closing streets for micromobility and restaurant uses (NUTC, 2020). Some specific strategies adopted by TransLink during the global crisis include (NUTC, 2020):

- Extensive sanitation of facilities and making disinfectants available in vehicles

- Raising awareness on coronavirus, requesting customers to be safe, practice adequate hygiene, and to follow social distancing rules (see Figure 14)

- Limiting fare gates to enter or exit only to support physical distancing on platforms and trains 
- Blocking every other seat to enable social distancing

- Moving services around as needed to cater high priority areas with greater demand during the pandemic

- Some other strategies proposed include feedback surveys for customers, recommending customers to ride during off-peak periods, working with provinces to provide funding to address deficits, starting reward program in order to regain customers, seeking collaborations with ridesharing service providers, launching innovation calls that can bring partners on board to help mitigate the COVID-19 risks, and planning to keep administrative employees working from home for few months.

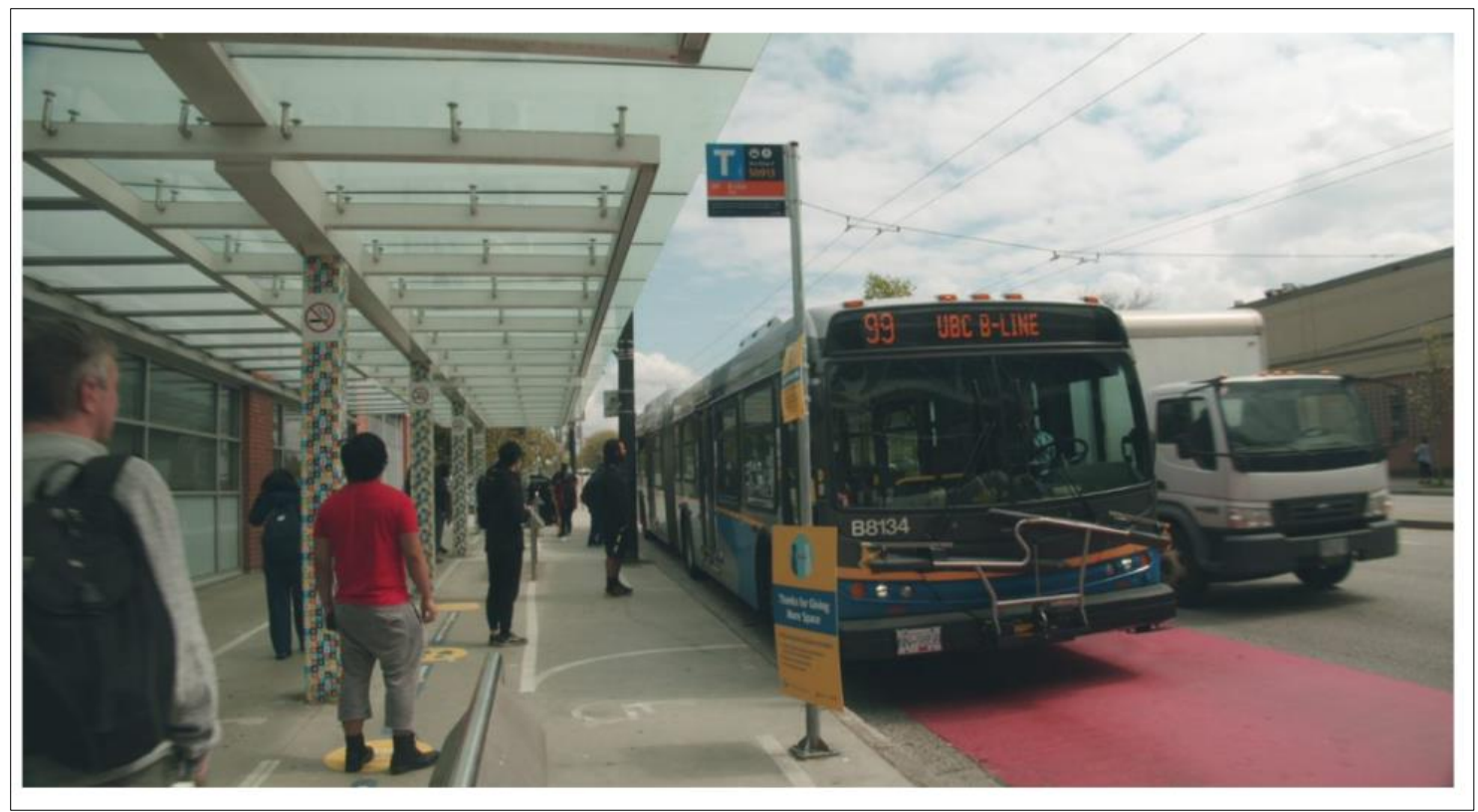

Figure 14. TransLink Social Distancing

(Source: TransLink, 2020)

\section{Transport for London (TfL) (London, United Kingdom)}

Transport for London (TfL) is a government agency in charge of the transport system in Greater London in the United Kingdom. In London, residents have been asked to avoid public transportation and to use it only if needed and during off-peak times. TfL has been working on strategies to regain customers' trust. Ninety percent of TfL revenues were lost due to the pandemic (NUTC, 2020). A few approaches used by TFL to combat the reductions during the COVID-19 pandemic include (NUTC, 2020, TfL, 2020):

- Asking customers to follow hygiene and social distancing measures, such as wearing a face covering over nose and mouth, and practice social distancing

- Using contactless method to pay for travel

- Providing hand sanitizers at stations

- Testing continuous UV cleaning of trains and escalator handrails (see Figure 15) 


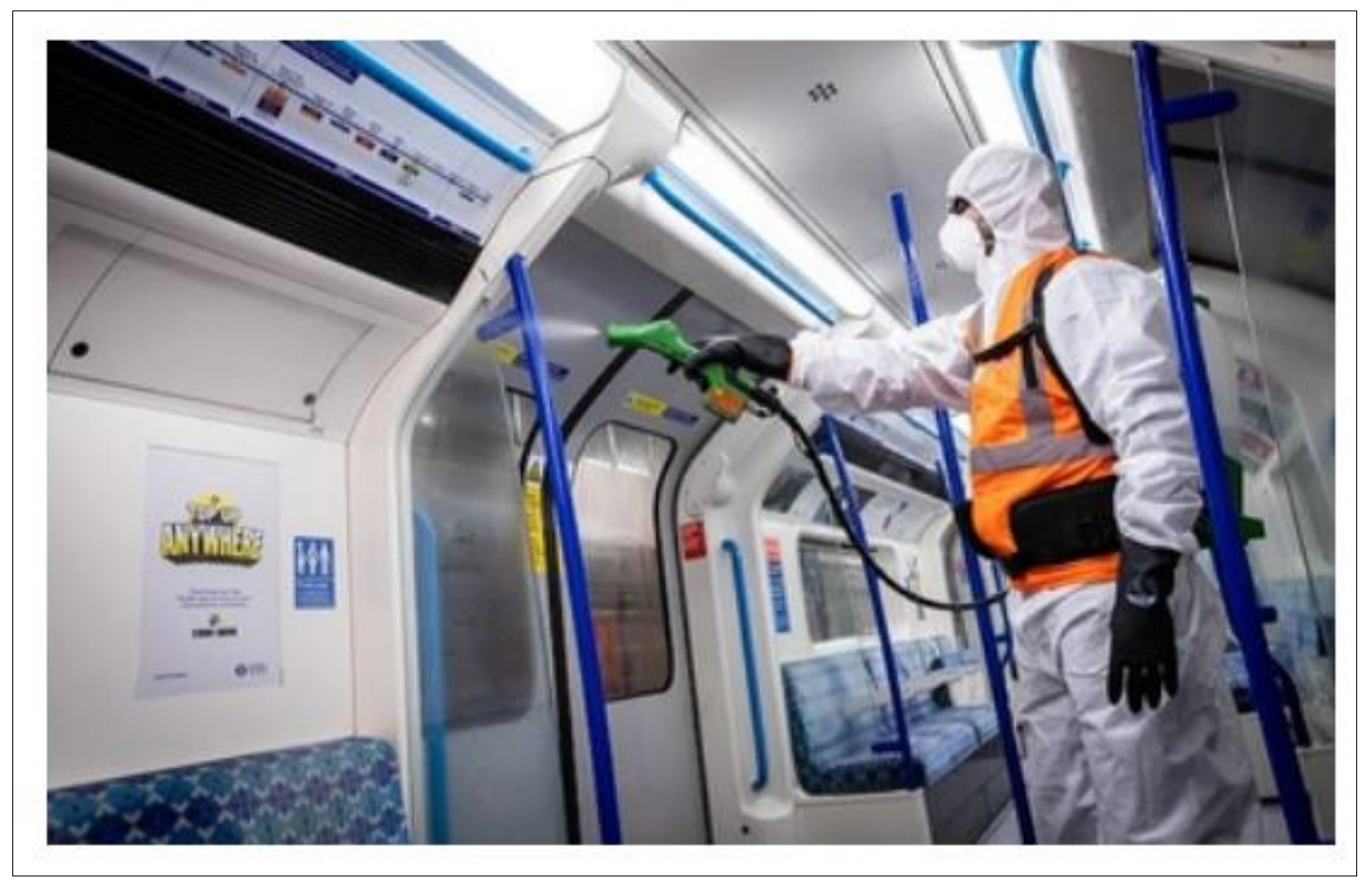

Figure 15. TfL Cleaning Process - Trains

(Source: TfL, 2020)

- Installing new signage, posters, and platform stickers across the network to help everyone maintain social distancing (see Figure 16).

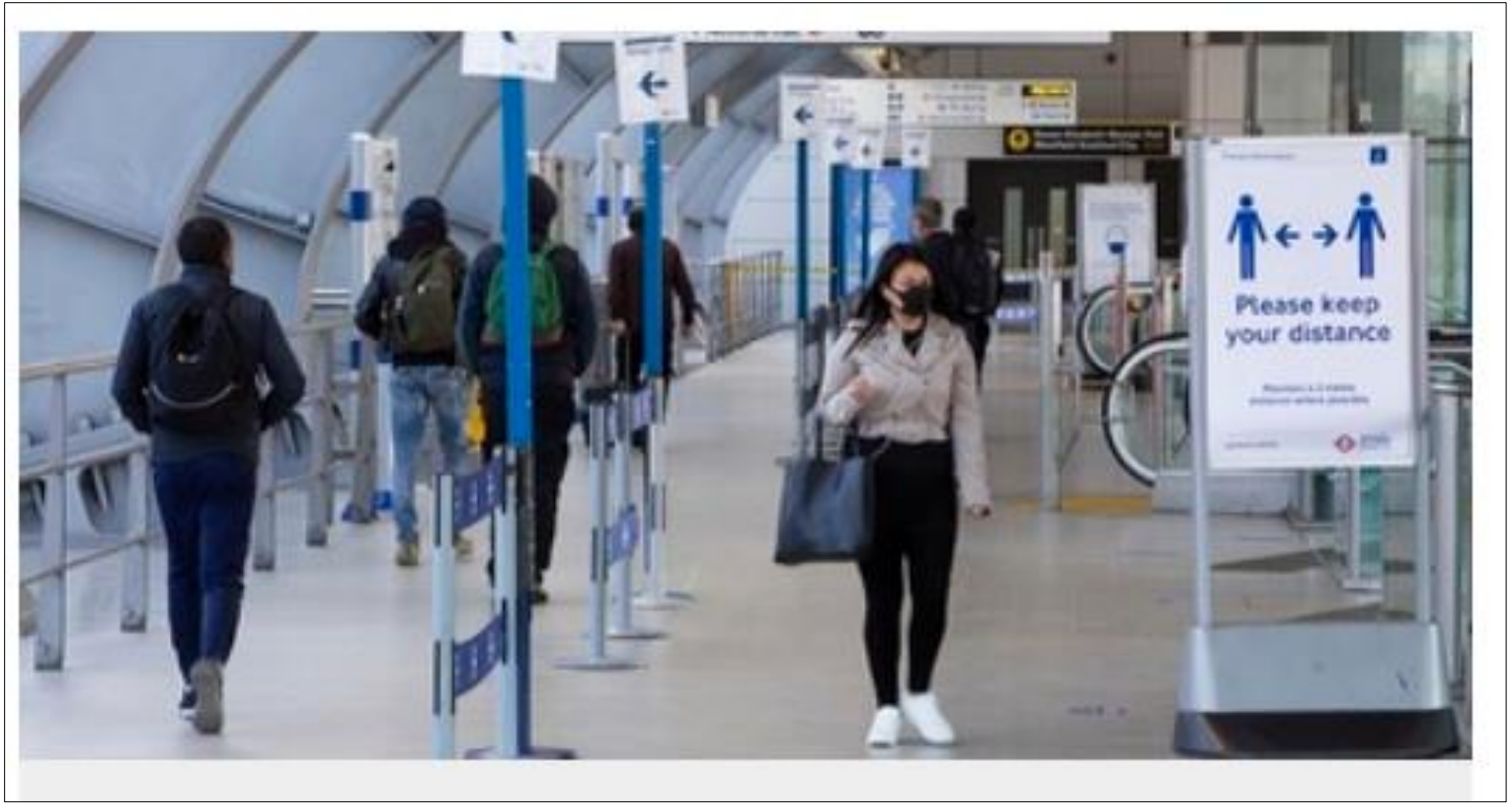

Figure 16. TfL COVID-19 Signages

(Source: TfL, 2020) 
- Using one-way system and queuing arrangements for passenger flows

- Making safety improvements to driver screens on buses, and taking the first and last sets of doors out of use on all trains

- Other strategies explored include approaching the government for stimulus funds, scenario development to contend with future circumstances, and encouraging nonessential employees to work from home for at least a few more months.

\section{Union Internationale des Transports Publics (UITP)}

The UITP brings together public transport stakeholders and sustainable transportation modes across the world. During the webinar, UITP stressed on the importance of resiliency during the crisis. Public transportation agencies across the world have faced up to 90 percent decreases in ridership. UITP suggests that the COVID-19 pandemic may lead to rethinking cities and changing people's long-term destinations (NUTC, 2020). The organization also affirmed that social distancing rules have evolved and have differed based on geographic locations.

UITP has seen numerous partnerships prosper between cities and transportation providers for creating dedicated transit lanes to hospitals. For UITP, integrating micromobility and mass transit is seen as an essential cog to maximize the use of both systems. In response to the virus, UITP launched a campaign called "Back to Better Mobility: Bringing our Cities Back to People". The campaign aims to demonstrate the future of cities with and without public transportation (NUTC, 2020). Additionally, UITP noticed the following practices, challenges, and outcomes across agencies worldwide during the outbreak (NUTC, 2020):

- Several agencies have been fervently stepping up their cleaning and disinfection initiatives

- Transit agencies have been executing social distancing and monitoring transportation supplies in light of new ridership levels

- Some agencies have used real-time demand information to adjust supply

- Most transit agencies have experienced revenue shortfalls (e.g., passenger and marketing revenues)

- There have been several instances of increasing public transportation expenditure in light of the pandemic outbreak due to additional cleaning and disinfecting requirements

- UITP also noticed growing digitization trends among transit agencies to combat the crisis.

\section{Ride-Hailing and Taxi Company Strategies}

Like many other sectors, the COVID-19 pandemic significantly affected TNCs and the taxi operators. For the uninitiated, TNCs are on-demand ride-hailing companies that use smartphone apps to connect riders with drivers. Some examples of TNC companies considered in this report include Uber, Lyft, and Dallas-based Alto. It was noted that some ridesharing companies altered 
their business models by adding new dimensions to their suite of offerings (such as food delivery services) as a consequence of the pandemic (Walters, 2020).

The Occupational Safety and Health Administration (OSHA) in the USA has provided the following recommendations to the car service industry (rideshare, taxi, and other car services) to help reduce the risk of exposure to the coronavirus (OSHA, 2020):

- Encourage drivers to stay home if they are sick.

- Ensure vehicle door handles and inside surfaces are routinely cleaned and disinfected with Environmental Protection Agency-approved cleaning chemicals that have label claims against the coronavirus.

- Advise drivers to lower vehicle windows to increase airflow.

- Allow drivers to wear masks over their nose and mouth to prevent spread of the virus and ask customers to do the same.

- Provide alcohol-based hand rubs containing at least 60 percent alcohol for both drivers and customers.

- Provide drivers with disposable towels.

- Provide drivers and customers with tissues and trash receptacles.

- Limit the number of passengers to drivers and install plexiglass partitions between driver and passenger compartments where possible.

- Encourage drivers to report any safety and health concerns.

A list of precautionary measures adopted by ridesharing companies during the global crisis are as shown in Figure 17.

\begin{tabular}{|l|l|}
\hline \multicolumn{1}{|c|}{ COMPANY NAME } & \multicolumn{1}{|c|}{ PRECAUTIONARY MEASURES ADOPTED } \\
\hline DiDi & $\begin{array}{l}\text { - Built disinfection stations across China for on-demand mobility } \\
\text { vehicles } \\
\text { - Invested about USD } 14.3 \text { million in this safety measure that involves } \\
\text { installing protective plastic sheets }\end{array}$ \\
\hline \multirow{3}{*}{ Uber } & $\begin{array}{l}\text { - Distributing disinfectants to drivers to help keep cars clean } \\
\text { - Reduced their fares during the pandemic } \\
\text { - Disinfecting all high contact surfaces on bikes and scooters in } \\
\text { respective depots } \\
\text { - Developed a new 'Work Hub' app to help drivers find alternative jobs }\end{array}$ \\
\hline \multirow{2}{*}{ Grab } & $\begin{array}{l}\text { - Providing face masks and hand sanitizers to drivers } \\
\text { - Temporarily suspended GrabShare and GrabBike services }\end{array}$ \\
\hline \multirow{2}{*}{ Ola } & $\begin{array}{l}\text { - Temporarily paused shared rides across all of its markets } \\
\text { - Over 200,000 bottles of hand sanitizers, along with other cleaning } \\
\text { supplies, are being distributed to Lyft drivers free of cost } \\
\text { - Disinfecting all high contact surfaces on bikes and scooters at } \\
\text { depots }\end{array}$ \\
\hline
\end{tabular}

Figure 17. Precautionary Measures Adopted by Ridesharing companies during COVID-19 Crisis (Source: Markets and Markets, 2020) 
In addition to the enhancing sanitation and disinfecting procedures, plexiglass sheets have been recommended as a key strategy. Many of these strategies are the same for taxi operators (TBRC, 2020; Lazo, 2020). A market analysis of the future for ridesharing revenues in a post-COVID world (as illustrated in Figure 18) shows a temporary decline in revenues but optimism that these numbers will rise up to almost pre-COVID levels by 2021.

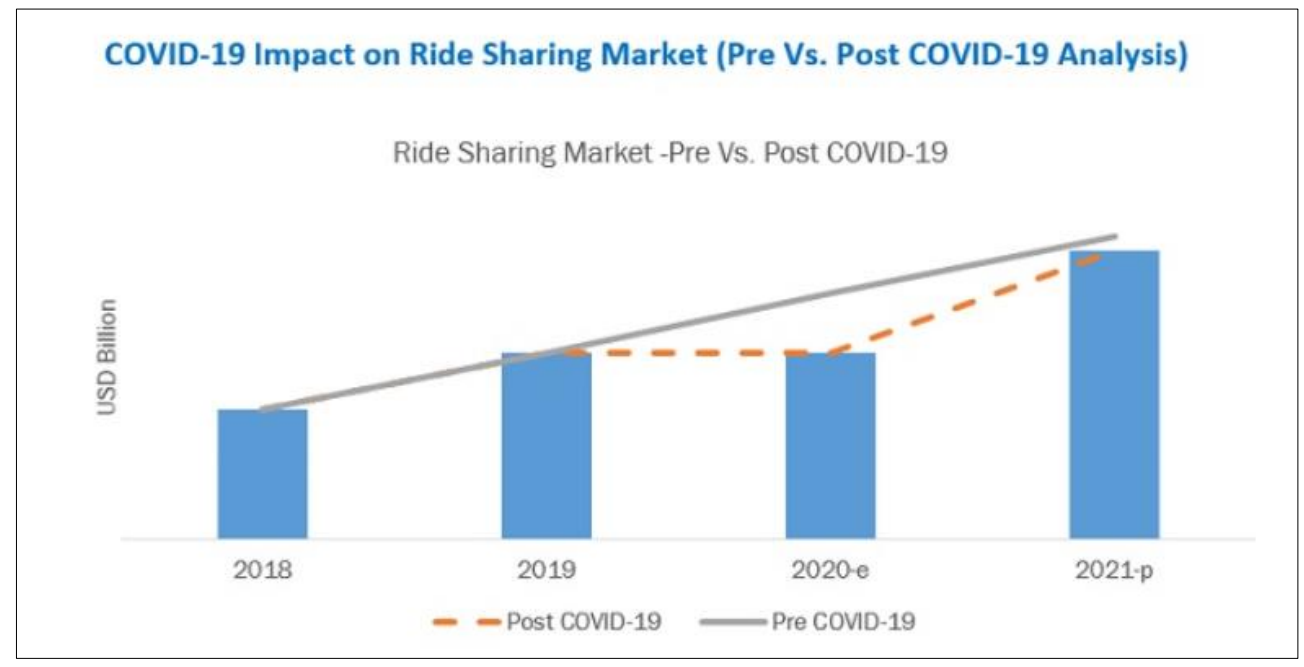

Figure 18. COVID-19 Impacts on the Ridesharing Market (Source: Markets and Markets, 2020)

\begin{abstract}
Alto
During the pandemic, ridesharing companies with their own fleet (e.g., Alto in Dallas) adopted several safety measures, including (Walters, 2020):
\end{abstract}

- Providing masks, gloves, and sanitation training for drivers

- Checking driver temperatures before each shift

- Installing plexiglass barriers between drivers and riders

- Providing a hospital-grade sanitizing mist that kills 99.9 percent of bacteria and viruses

- Having HEPA air filters in the cars - the same type that has been used in hospitals to provide clean air.

\title{
Uber
}

Uber has been significantly affected by the COVID-19 crisis. Specifically, its ride-hailing services have decreased by 80 percent and the company had planned to lay off about 14 percent (about 3,700 full-time employees) of its workforce during the pandemic. Some of the strategies used by Uber in response to the COVID-19 include (Hawkins, 2020; Ellison, 2020; Bond, 2020; Uber, 2020):

- Requiring face masks (spending up to $\$ 50$ million in face masks, hand sanitizers, and bleach wipes)

- Requiring selfies for drivers (showing that their face masks are on) 
- Encouraging drivers to cancel rides with passengers not wearing masks (see Figure 19)

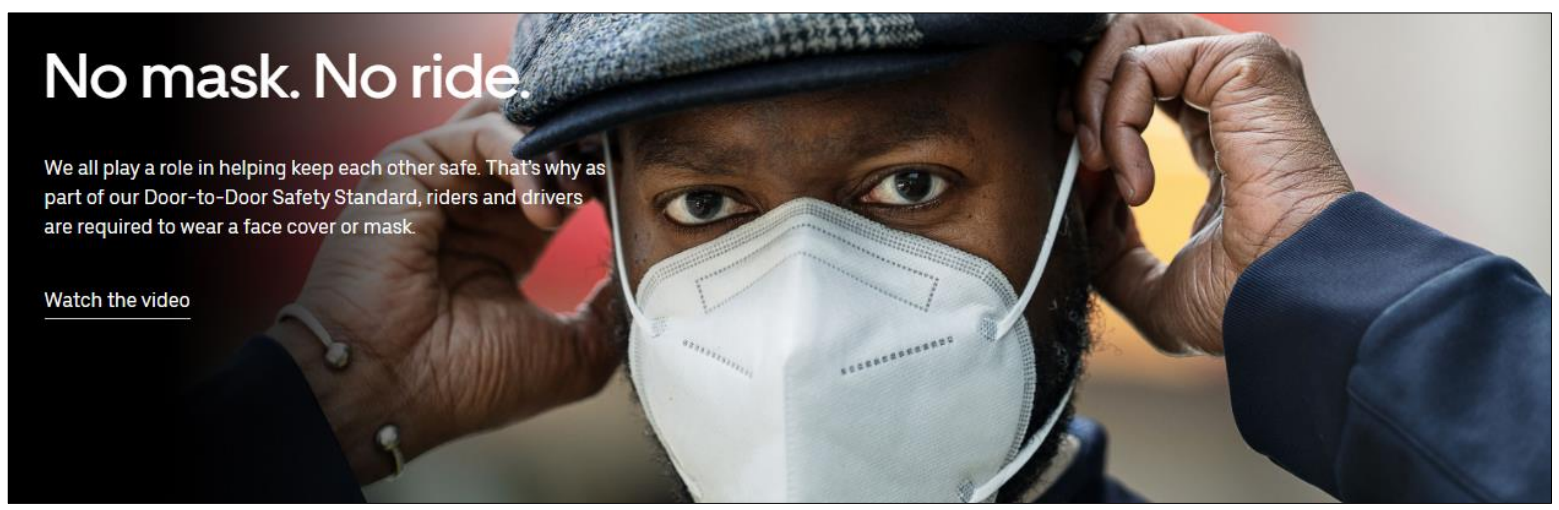

Figure 19. Uber No Mask No Ride

(Source: Uber, 2020)

- Keeping windows rolled down for better air circulation in the car

- Requiring fewer people in the car (limiting the total number of passengers in the car from four to three)

- Suspending pool and shared rides

- Requiring passengers to ride in the back seat

- Increasing reliance on rating and feedback systems for appropriate action against violators (drivers and riders), such as deactivation from the app or removal from the platform

- Transitioning ride-hailing business to add critical delivery service; for example, the San Francisco-based company built upon its Uber Eats food (see Figure 20) and grocery delivery service to create Uber Direct and Uber Connect in select cities.

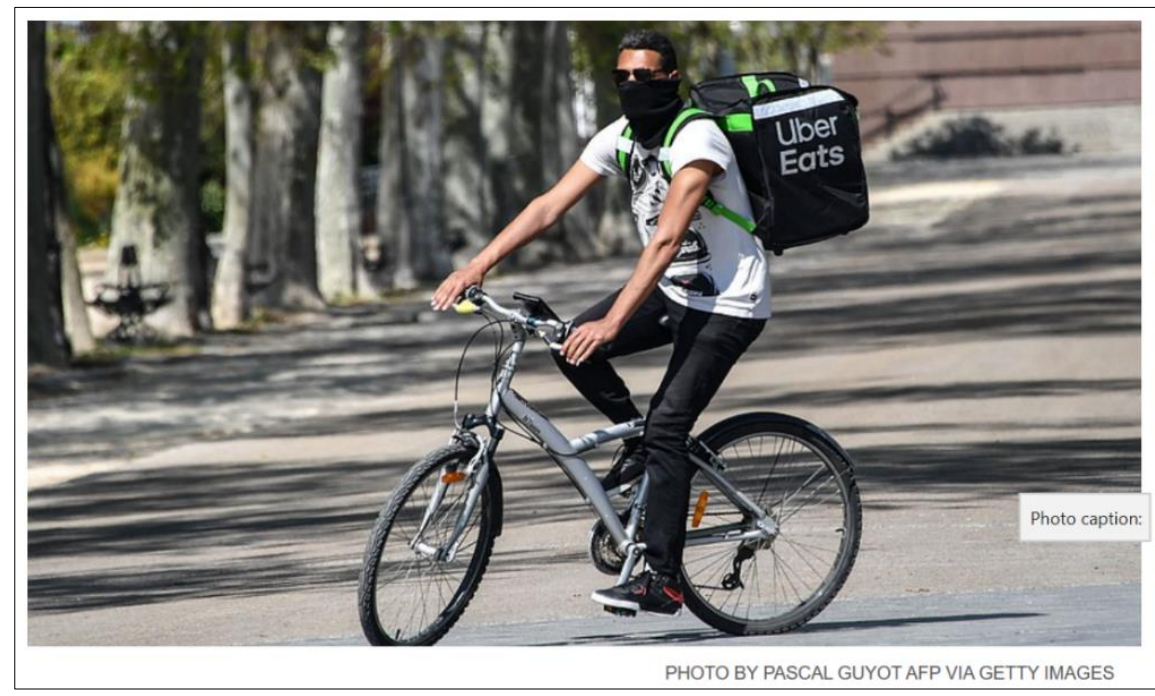

Figure 20. Uber Eats Food Delivery Service

(Source: Bond, 2020) 
- Uber Direct service delivers retail goods, including over-the-counter medications and pet supplies, to consumers (varied forms of Direct have launched initially in New York City, Portugal, Australia and South Africa, where the project teamed with the Bill and Melinda Gates Foundation to deliver medication to 25,000 people most vulnerable to COVID-19 Uber plans to expand the delivery service to other locations as needed).

- Uber Connect allows people to stay connected to loved ones through the delivery of care packages, household supplies, and even toys and games. Uber Connect is a same-day and contactless delivery service that keeps people feeling close.

\section{Lyft}

Lyft has distributed over 160,000 sanitizing products and face coverings at no cost to drivers. The company also plans to spend $\$ 2.5$ million in supplies (e.g., masks, bottles of hand sanitizer, wipes) for drivers. A few requirements by Lyft (similar to Uber) are that:

- Drivers and riders stay home if they have COVID-19 or related symptoms.

- Drivers and riders wear a face covering,

- Drivers keep the car and their hands sanitized at all times.

- Riders sit only in the back seat

- Drivers keep the car windows open for better air circulation.

In response to the pandemic, Lyft also created Personal Health Certification and a Health Safety Program covering health-related policies, commitments, and products. With the certification, Lyft anticipates riders and drivers to follow the requirements in the program in order to use the system. Lyft's Health Safety Program consists of (Lyft, 2020).

\section{Car Rental Strategies}

Similar to other shared mobility systems, the car rental sector has also been impacted by the COVID-19 crisis. Some of the strategies explored by rental car companies include (Thompson, 2020; Staff, 2020; Tierney, 2020, Auto Rental, 2020):

- Frequent cleaning and disinfecting of vehicles and facilities

- Offering COVID-19 safety training for employees

- Providing low-tech contactless rental processes and paperless options

- Enabling creative procurement methods

- Collaborating across sectors (e.g., working with insurance companies) to minimize impacts including considerations for industry consolidations

- Providing free cancellations or travel credits on all existing reservations.

The COVID-19 crisis has negatively affected car rental companies, potentially leading to reduced used car prices thereby make car affordable for some additional segments of the society. 
Figure 21 and Figure 22 illustrate some procedural modifications incorporated by rental car companies in light of the pandemic. While a large majority of strategies worked in favor to the customers and the rental car companies, few strategies did not yield encouraging results. These include:

- Provision of extra free miles

- Adjusted rental car rates for more extended periods

- Modified deposit requirements.

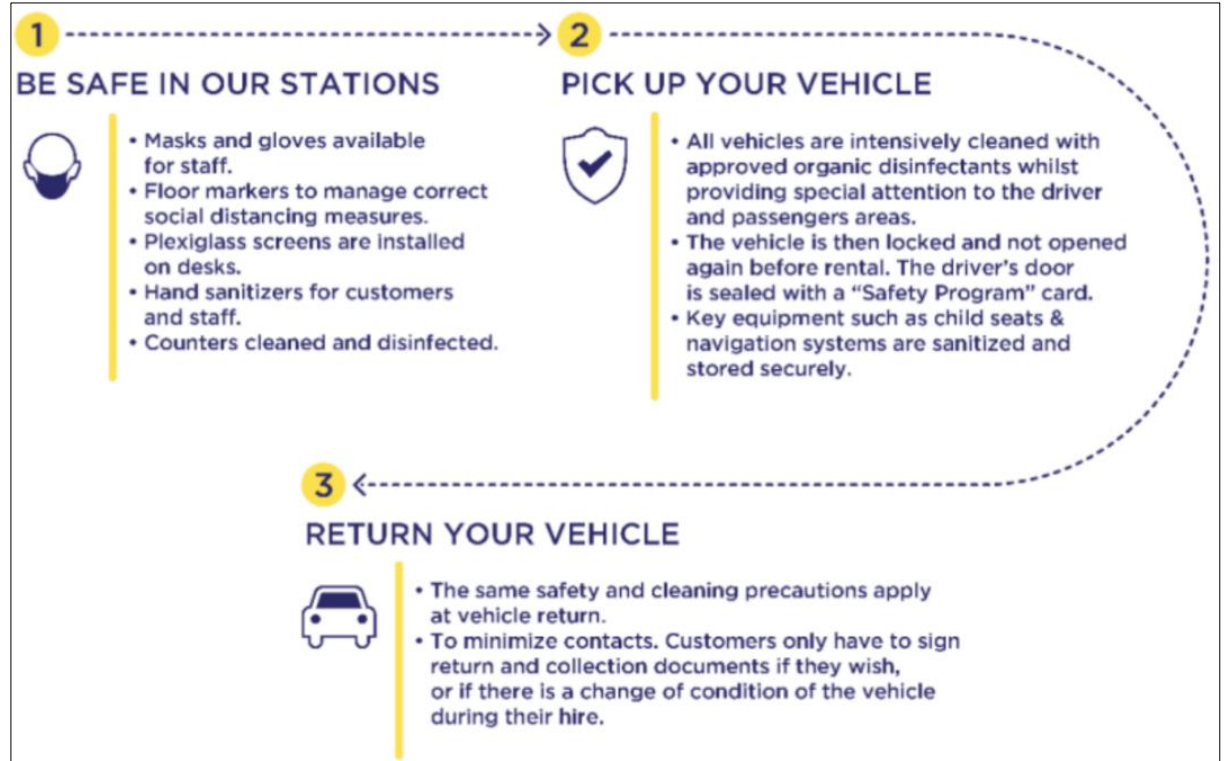

Figure 21. Example Car Rental Process During COVID-19 Pandemic (Source: Fox Rent A Car, 2020)
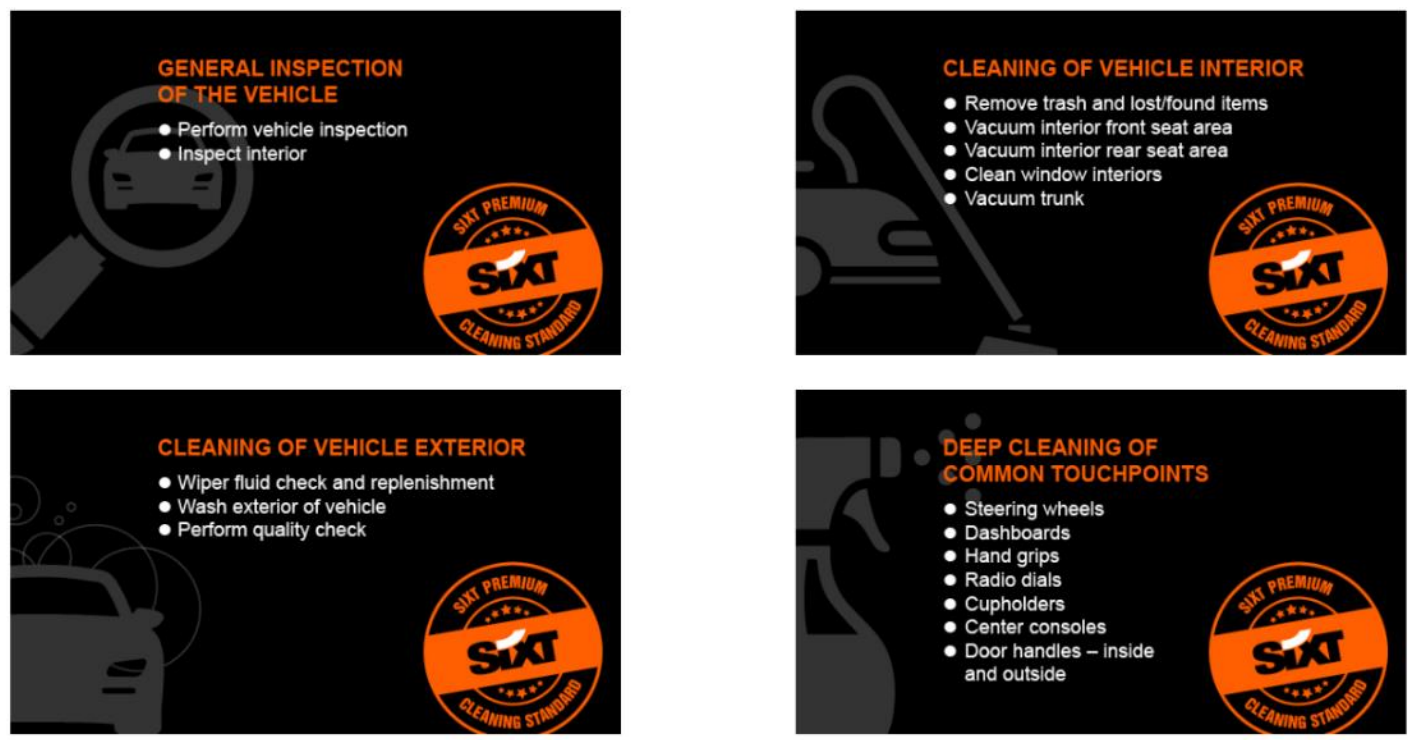

Figure 22. Example Car Rental Cleaning Procedures

(Source: Sixt, 2020) 


\section{Micromobility Strategies}

The novel coronavirus had also plummeted consumer use of micromobility modes globally as evidence (Heineke et al., 2020) suggests a 50 to 60 percent decline in the number of passengerkilometers traveled (see Figure 23). For example, e-scooter ridership dropped considerably during the outbreak. Consequently, micromobility companies (such as Lime and Spin) and cities are adopting safety measures to avoid the spread of the virus (Ferenchik, 2020; Theen, 2020, Lyft, 2020; Naka, 2020) during and after reopening. Some strategies considered include:

- Frequent disinfecting and cleaning with special focus on handlebars

- Requiring users to wear masks, gloves, along with regular washing of hands

- Providing services near medical centers, offering free 30-minute rides for healthcare workers

- Attaching hand sanitizers to each scooter

- Making pedal-less e-bikes with self-cleaning handlebars available to essential workers

- Providing field service staff with protective gloves

- Classifying bike shops as essential businesses.

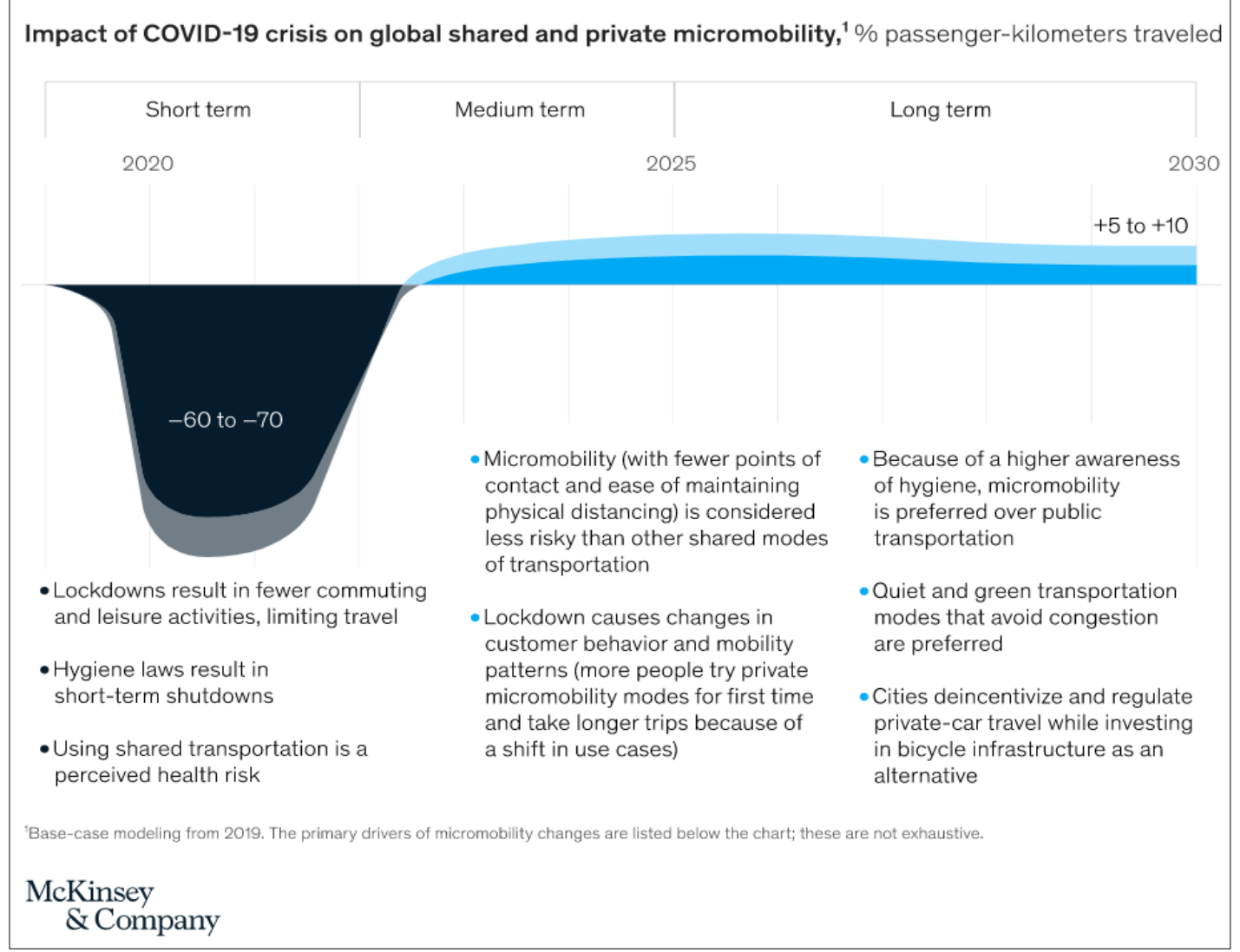

Figure 23. Micromobility Post-Pandemic Recovery

(Source: Heineke et al., 2020) 
The study by McKinsey (Heineke et al., 2020) also demonstrated how consumer concerns have shifted pre- and since- COVID-19 when it comes to choosing shared micromobility services. While travel time was the top concern during business/commuting, and personal trips, the prospect of infection spread emerged as the top concern among users in post-pandemic era. This could be attributed to the rapid decline in micromobility ridership levels (see Figure 24). It is interesting to note how travel time and convenience/comfort decisions have taken a back seat in light of the COVID-19 pandemic, thereby providing potential directions for future micromobility operations.

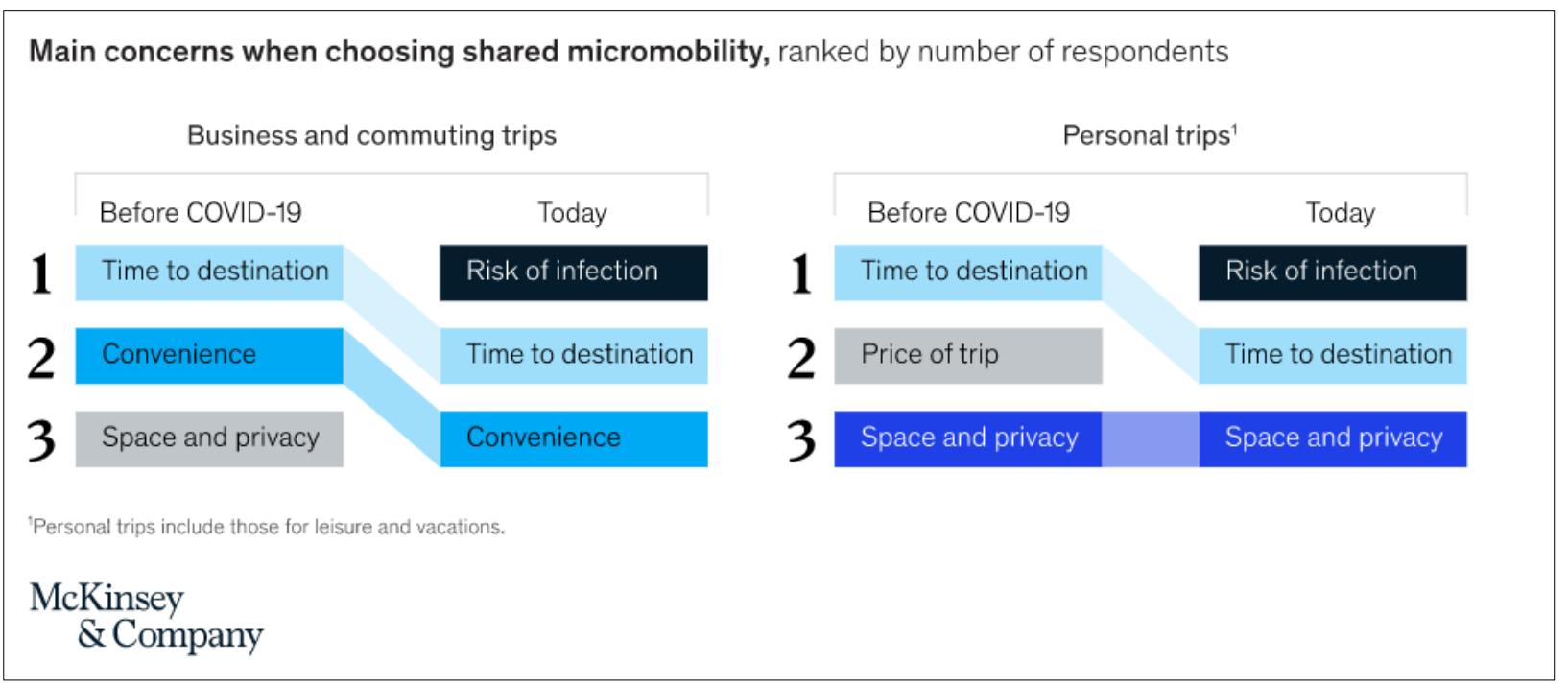

Figure 24. Micromobility Users' Top Concerns - Pre- and Post-COVID-19 (Source: Heineke et al., 2020)

During the pandemic, many locations have re-envisioned transportation by making streets or portions of streets strictly available to pedestrians, bicyclists, and other micromobility users. Several cities such as San Jose, Oakland, Boston, Chicago, New York City, Baltimore, Los Angeles, Portland, Kansas City and Detroit have offered free access to e-scooters or bikeshare for essential workers and often for all community members during the crisis. Creating open spaces for micromobility may have lasting advantages after social distancing restrictions are removed (Laser, 2020).

New York City is an example of cities that have closed several streets to vehicular traffic to encourage walking and biking while social distancing during the crisis (Naka, 2020). The city of Denver, Colorado also has embraced this practice during the COVID-19 outbreak (Bird Cities Blog, 2020). After closing a large portion of their streets to through traffic the city experienced four times more cyclists and pedestrians in April 2020 than usual. More importantly, the longterm practice of opening more spaces for micromobility was appreciated by 90 percent of residents (Bird Cities Blog, 2020). 
Outside the United States, the city of Berlin (Germany) created temporary "pop-up" bike lanes (refer to Figure 25) to boost micromobility during the global outbreak. After widening two bike lanes to enable social distancing for users, the approach became successful across Germany with more than 130 German cities requesting similar infrastructure (Bird Cities Blog, 2020).

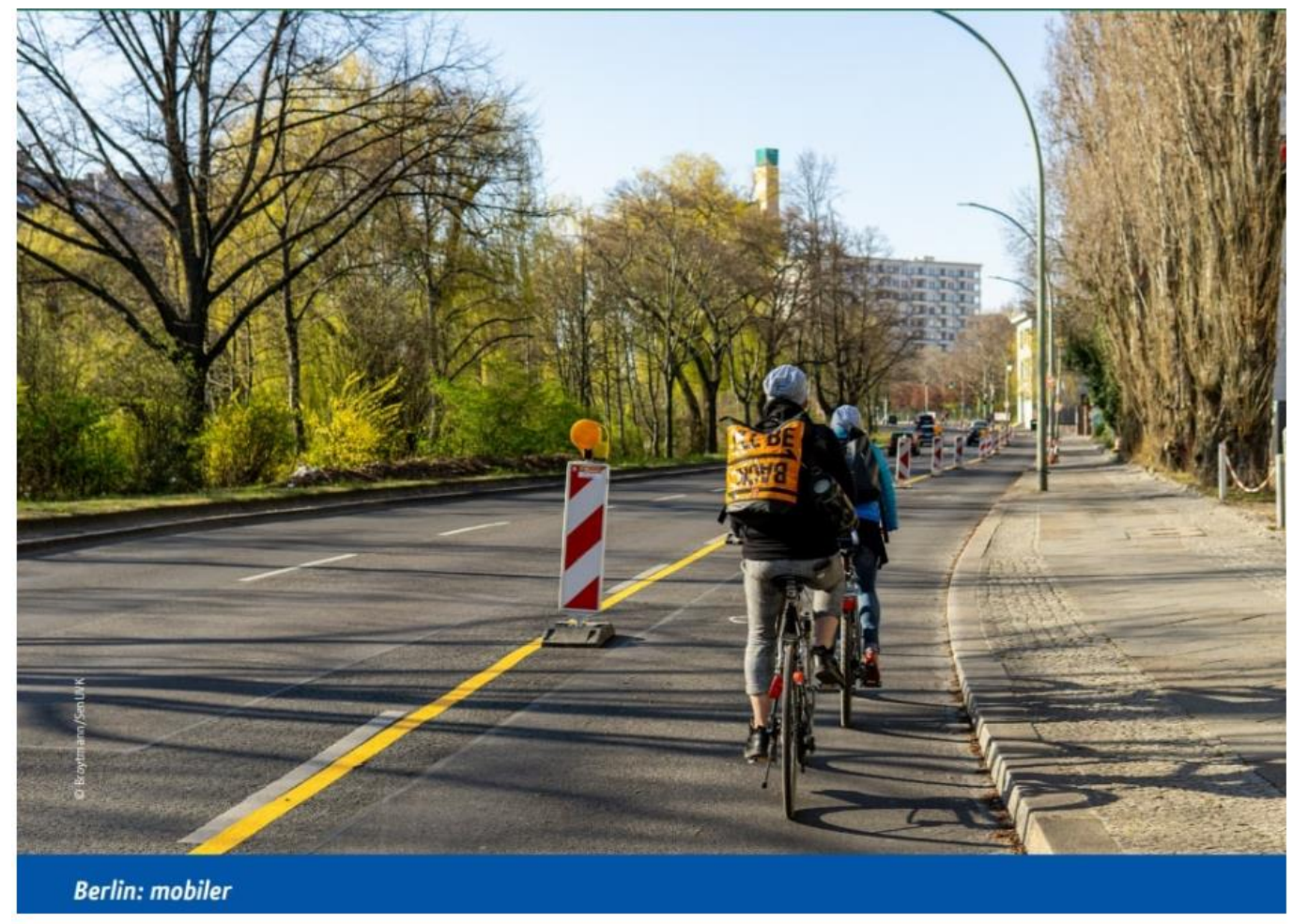

Figure 25. Pop-up Bike Lanes in Berlin (Germany)

(Source: Bird Cities Blog, 2020)

Other cities such as Milan (Italy), Paris (France), Brussels (Belgium), and Bogota (Colombia) are also adopting and considering similar approaches (Heineke et al., 2020). They include:

- Milan has announced that $35 \mathrm{kms}$ of streets previously used by cars will be transitioned to walking and cycling lanes after the lockdown is lifted.

- Paris has plans to convert $50 \mathrm{kms}$ of lanes, usually reserved for cars to bicycle lanes. It also has planned to invest $\$ 325$ million to update its bicycle network.

- Brussels has already turned $40 \mathrm{kms}$ of car lanes into cycle paths.

- Montreal announced the creation of more than $320 \mathrm{kms}$ of new pedestrian and bicycle paths across the city.

A comprehensive list of actions around the world to adapt to COVID-19-induced changes in demand for safe spaces to walk, bike, roll, park, dine, play, and relax are provided in Combs et al. (2020). 


\section{Stated Preference Survey: Some Initial Findings}

In order to gain insight on the impacts of COVID-19 on travel behavior and shared mobility systems, multipronged approaches were used. First, a comprehensive web review was conducted. Section 2 highlights the findings from this effort. The sources for this review included journal articles, pre-print academic literature, web-based articles, and information from webcasts and webinars. The information acquired from the webinars was also supported with evidence from agency websites. Additionally, the research team also designed and developed a comprehensive web-based stated preference survey to collect data pertaining to the impacts of the COVID-19 pandemic on travel behavior and shared mobility systems.

\section{Study Design}

Based on the information collected and reviewed in the first half of the report, a comprehensive review of the components of the survey was conducted during the initial phase of this project. While it was important to capture the impact of the COVID-19 pandemic on travel behavior and shared mobility systems, it was also important to build the foundation from which these impacts could be best determined. For this purpose, the research team developed a comprehensive data collection instrument that collected not just information since the onset of the COVID-19 pandemic but also that from a time before and after (hypothetically, when the COVID-19 pandemic is no longer a threat).

A full list of survey goals, objectives, research questions of interest was compiled by the research team. It was important to understand the public perceptions, opinions, and attitudes to travel, trip-making, and activity engagement in a pre-COVID era to effectively gauge the array of changes since the onset of the pandemic. Therefore, the questionnaire was designed to identify how people's travel patterns (and needs), residential choices, vehicle ownership, mode choice, use of shared mobility systems, and trip-making/activity engagement using conventional and ICT-enabled approaches will alter in light of the global pandemic. Finally, a section of the survey was also devoted to understanding public opinions and perceptions regarding emerging transportation technologies such as automated vehicles and understanding the potential impact of the pandemic in people's preferences for these technologies. Based on these aspects, the survey was developed into six sections:

- Section A - Background Information: sociodemographic information, such as age, gender, race, place of birth, education attained, household information, and income.

- Section B - Travel Characteristics, Activity Participation and Preferences during the pre-COVID era: description of vehicles available to the household, housing characteristics, employment/school information, and detailed trip-making and activity engagement information during the pre-COVID era.

- Section C - Travel Characteristics, Activity Participation and Preferences during the COVID era: description of changes to household vehicles, housing characteristics, 
employment/school information, and detailed trip-making and activity engagement information since the onset of the COVID-19 pandemic.

- Section D - Shared Mobility Usage and Activity Participation in the Era of the Pandemic: detailed understanding of public opinions and attitudes towards the strategies employed by shared mobility systems in the era of the pandemic.

- Section E-Travel Characteristics, Activity Participation and Preferences during the post-COVID era: respondent preferences for housing, vehicle purchase, employment/school, and other travel, and detailed trip-making and activity engagement in an era when the COVID-19 is no longer a threat.

- Section F-Autonomous Vehicles in the Era of the Pandemic: public perception, opinions, and attitudes towards emerging transportation technologies (such as the automated vehicle) in light of the COVID-19 pandemic.

\section{Data Collection}

The University of South Florida (USF) Office of Research Integrity and Compliance processed this study request and determined it as "Exempt" from the Institutional Review Board (IRB) review (IRB\#: STUDY001076). The web-based survey was developed using the survey platform Qualtrics. Pilot deployments were conducted internally within the researchers' organization in order to solicit early feedback on the study design, with emphasis on wording of the questions, their tone, any potential redundancies, and overall brevity of the data collection effort. Once the feedback obtained was used to rectify the data collection instrument, a final version of the survey questionnaire was administered through a nationwide panel (Prime Panels) in July-August 2020.

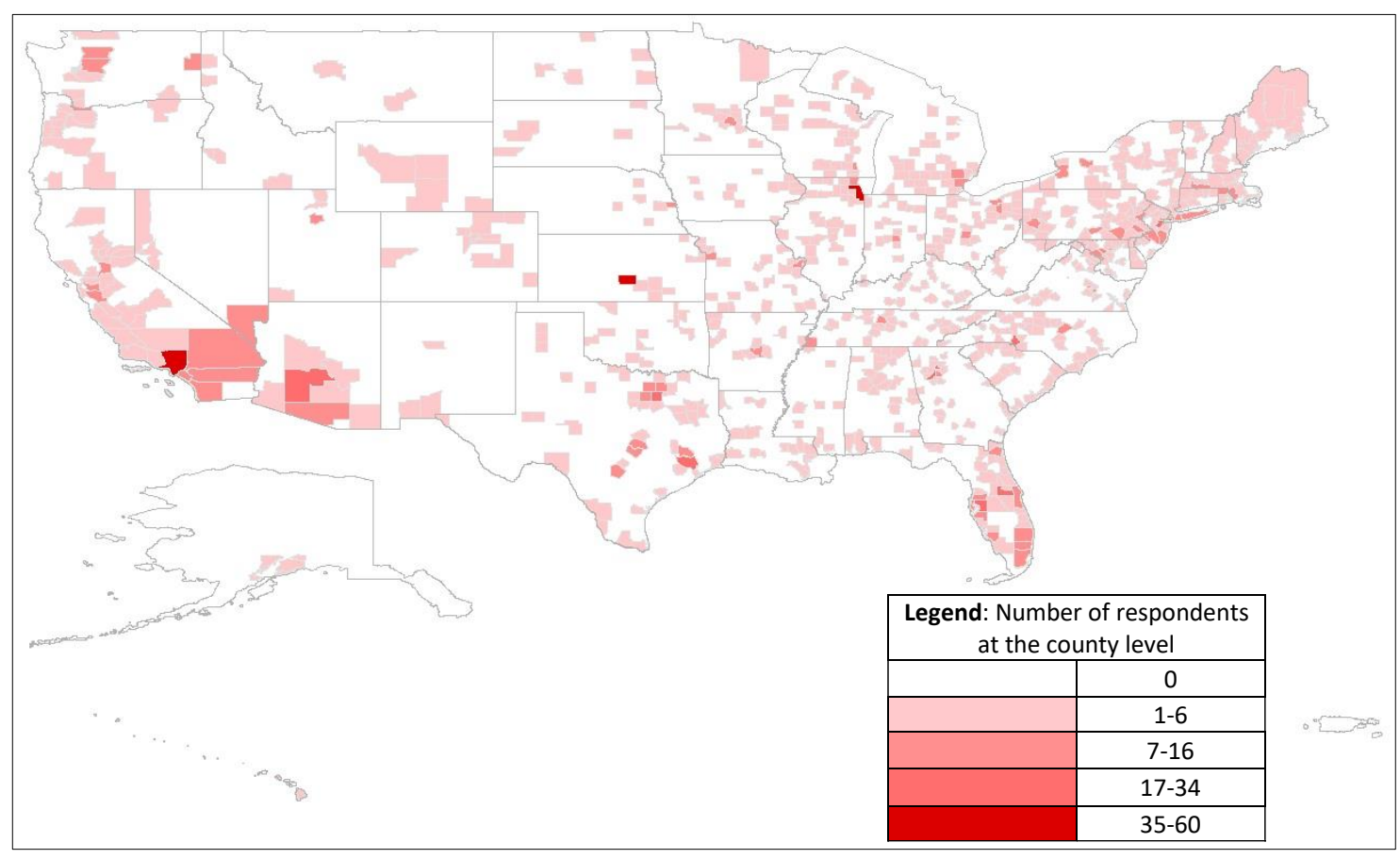

Figure 26. Spatial Distribution of Survey Responses 
As part of the research effort, $\$ 5,000$ was set aside for the data collection - to be provided as incentives or consultant fees to the data collection platform. After reviewing a host of data collection platforms (Amazon Mechanical Turk, Facebook ads, Qualtrics Panels, Prolific Panel) the research team finally chose to proceed with Prime Panels (also known as Turk Prime) for data collection. Prime Panels have been found to be an effective method for collecting survey data in academic settings (CloudResearch, 2020).

Figure 26 shows the spatial distribution of survey responses obtained for this study. It can be seen that survey responses were received from all 50 states across the United States. 3,369 completely submitted responses were collected as part of using Prime Panels before employing QC/QA procedures to extract good quality data for further analyses and investigations. Several QC/QA and sanity checks procedures were conducted: first, premature completion of responses was investigated. The average response time for completing the survey was 16 minutes; any respondent who spent 7 minutes or less to complete the survey was deemed to have prematurely completed the survey. They were removed from the analysis.

Second, missing entries were analyzed and where missing entries corresponded to more than one-fifth of the total number of questions, they were removed from the analysis as well. Straight-lining of responses were detected, and these erroneous responses were removed from the final sample size. Lastly, any missing entries in any of the variables of interest were also investigated and removed from the survey database leaving a final clean sample size of 2,432. In the final sample, more than 175 responses were received from states such as Florida (219), New York (193), Texas (186), and California (176). On the other hand, Alaska (3) and mainland states such as Montana (3), New Mexico (3), Wyoming (4), and South Dakota (4) recorded the least number of responses.

\section{Initial Findings}

2,432 complete and unique responses were chosen to be part of the final dataset. The data collection involving the nationwide panel has ceased but a second phase of data collection involving a convenience-based sample of responses is being planned by the research team for Fall 2020. While a comprehensive analysis of each of the survey questions from the first phase of data collection is beyond the scope of this report and study, the research team is currently in the process of making the analysis results publicly available by the end of Fall 2020. The web platform featuring the results would be updated (on a monthly basis) with all the results from the first phase as well new responses collected from the second phase of data collection. The rest of this section outlines the initial findings from the data collection.

\section{Unweighted Socioeconomic Profile}

Some basic background information on each survey respondent was collected in the first section of the survey. The collected sociodemographic and individual attributes included age, gender, educational level, place of birth, Hispanic origins, ethnicity, driver licensure, technology adoption behavior, and household-level attributes such as information on household members, 
working status, children, driver licensure among household members, and annual household income.

Based on the collected data, female respondents (65 percent) outnumbered male respondents (34 percent) across the survey. While the survey certainly overrepresents women (refer to Figure 27), nationally, it correctly captures the transgender or gender non-conforming section of the American society (0.5 percent). Comparisons have been made with the American Community Survey (ACS) 2018 5-year estimates to better understand the collected sample and its representation of the country's demographics. Respondents 18 years or over were eligible to take part in this study. Results from Figure 28 show that the survey seems to have captured more representation in the 35-44 years, 55-64 years, and the 65-74 year age categories. All other age categories are accurate, as per ACS 2018 5-year estimates for the United States.

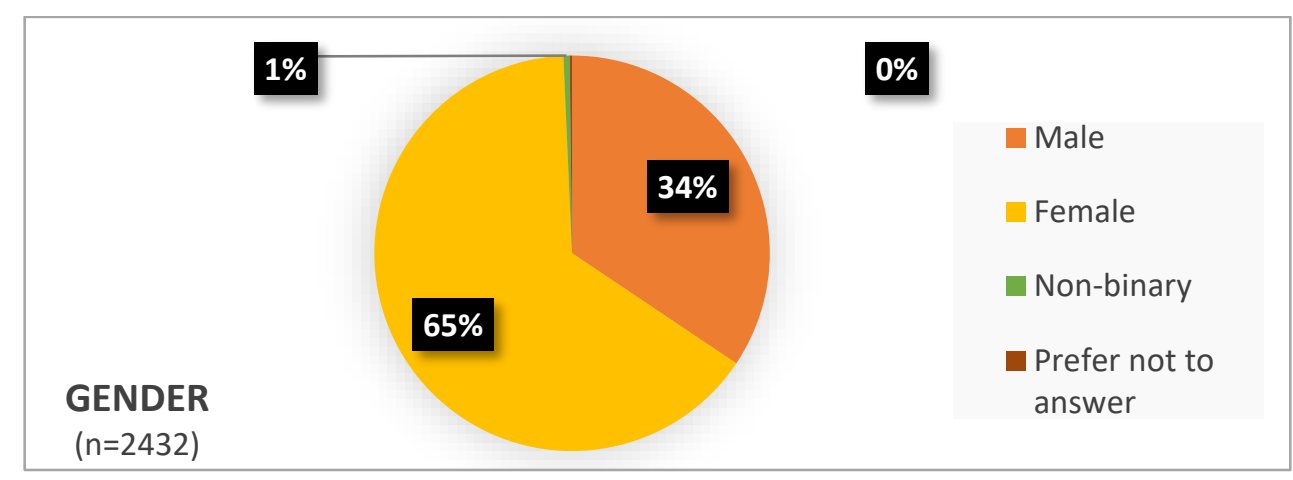

Figure 27. Respondent Gender

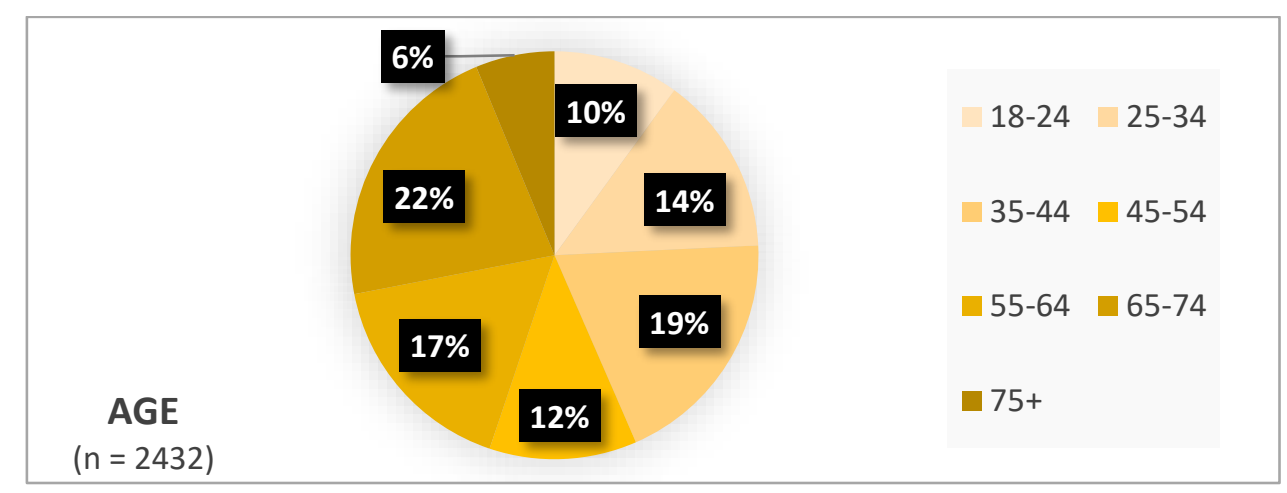

Figure 28. Respondent Age

A majority of the respondents (78 percent) identified themselves as White while close to 9 percent of the respondents were of African American ethnicity (refer to Figure 29 below). Other minority population segments such as Asians and Native American Indians constituted roughly 5 percent each in the survey sample. In comparison to the ACS statistics for the United States, the surveyed sample slightly overrepresents Whites (78 percent vs 72 percent) and slightly underrepresents Black/African American (8.7 percent vs 12.1 percent) races. 


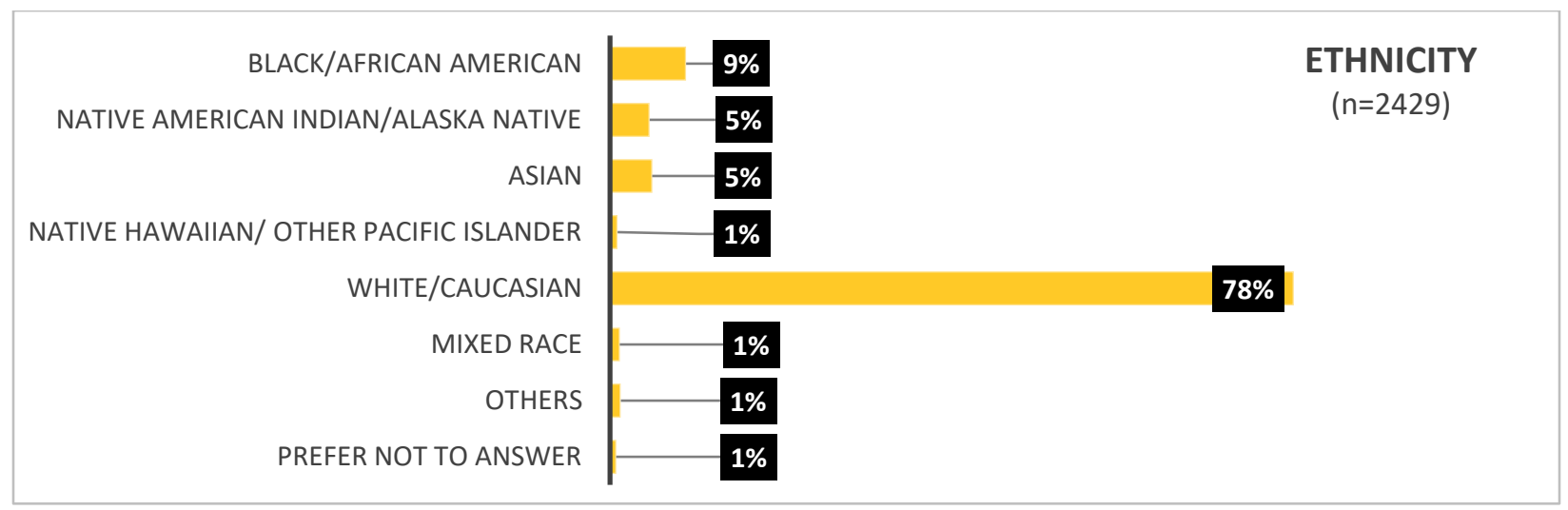

Figure 29. Respondent Ethnicity

Almost half of the respondents (46 percent), at the time of data collection, had completed at least a bachelor's degree while more than three-fourths of the survey respondents from Prime Panels had at least attended some college or technical school, as can be seen in Figure 30. Comparison with ACS estimates for the United States show that the survey overrepresents higher education categories. Perhaps unsurprisingly, an overwhelming majority of the survey respondents ( 88 percent) possessed a driver's license potentially indicating to varying travel behavioral trends that will be of significance later in the study.

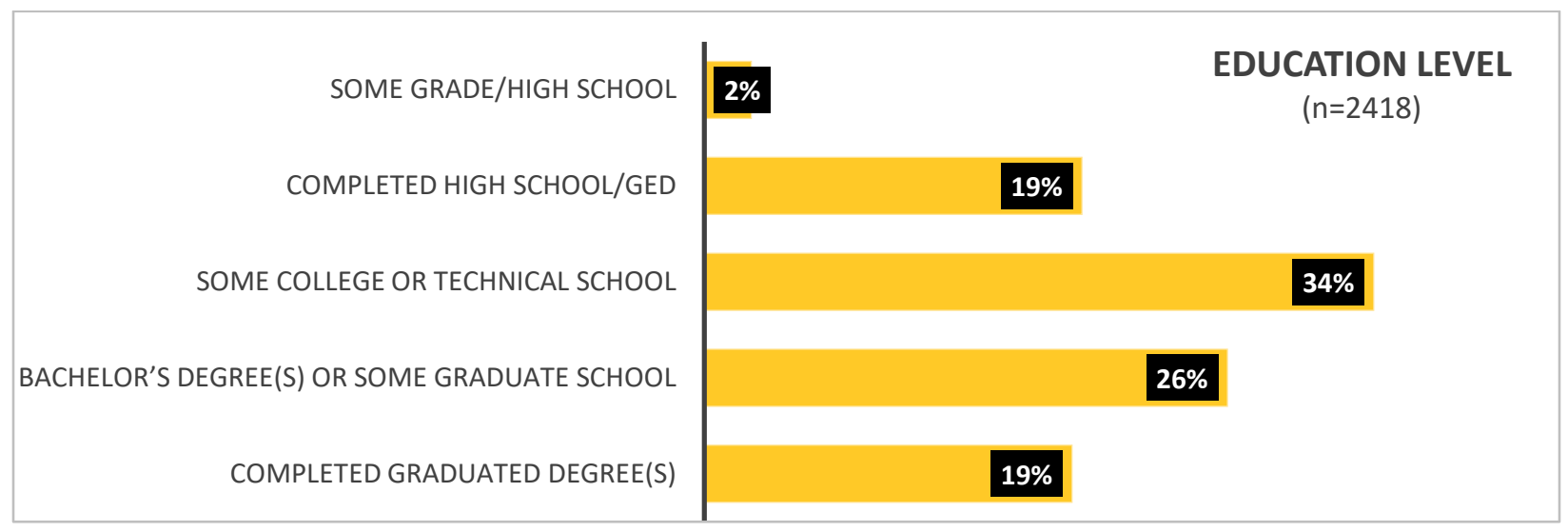

Figure 30. Respondent Educational Level

Initial results also show interesting insights on technology adoption behavior of the current sample. Results reveal that the current sample is on the cautious side with respect to their tech adoption behavior with more than one-third of the respondents being either one of the last to use new technologies or use them only if they have to. This is an interesting statistic to consider keeping in mind the important implications for technology usage in a post-pandemic world. ICT and other emerging technological solutions have emerged as ways for people to conduct their activities and substitute travel (in some cases), therefore the current results stand to provide insightful findings in this arena. Only 10 percent of the survey respondents consider themselves 
to be tech evangelists (see Figure 31, for reference) while a further 40 percent of the respondents like to follow their peers when it comes to new technology adoption (like to use new technologies based on how people around them use these technologies).

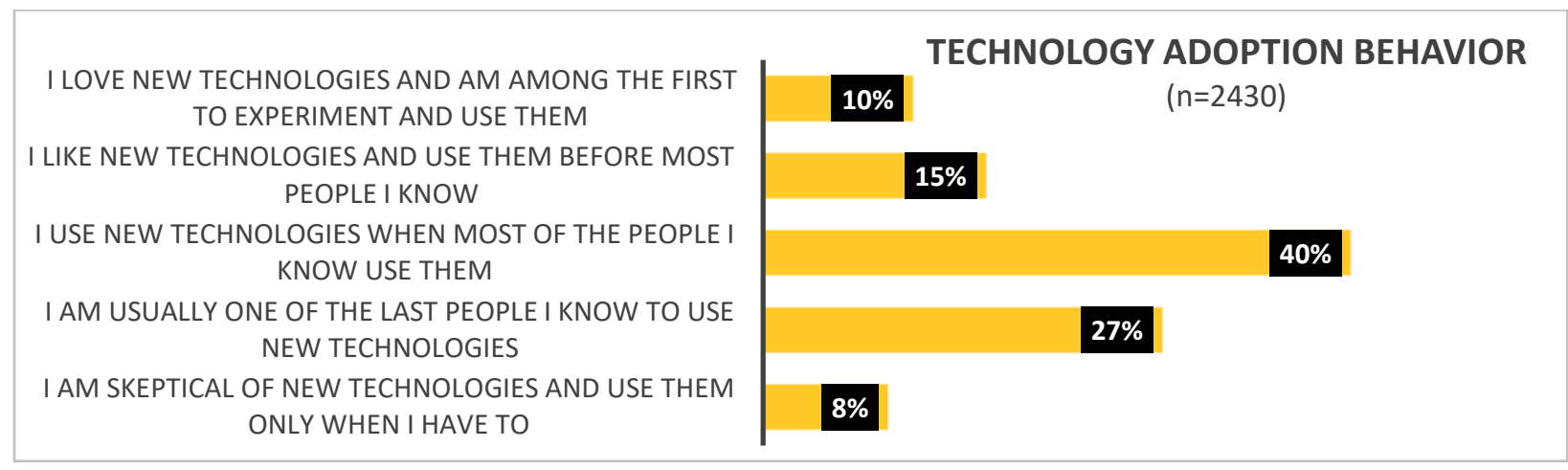

Figure 31. Technology Adoption Behavior

Annual household income is an important predictor for current and future trip making and activity engagement. Initial results from the stated preference survey show that one-fifth of the respondents belong to households that brought in less than $\$ 25,000$ per annum (pre-tax) in 2019 (Figure 32). In contrast, another one-fifth of the respondents belong to households that brought in at least $\$ 100,000$ in 2019. Lastly, almost half of the respondents belonged to households that brought in less than $\$ 50,000$. Comparing the sample with ACS estimates for the United States, it can be seen that the survey slightly overestimates some categories $(\$ 25,000$ to $\$ 49,999$, and $\$ 150,000$ or more) while the large majority of the trends are captured well.

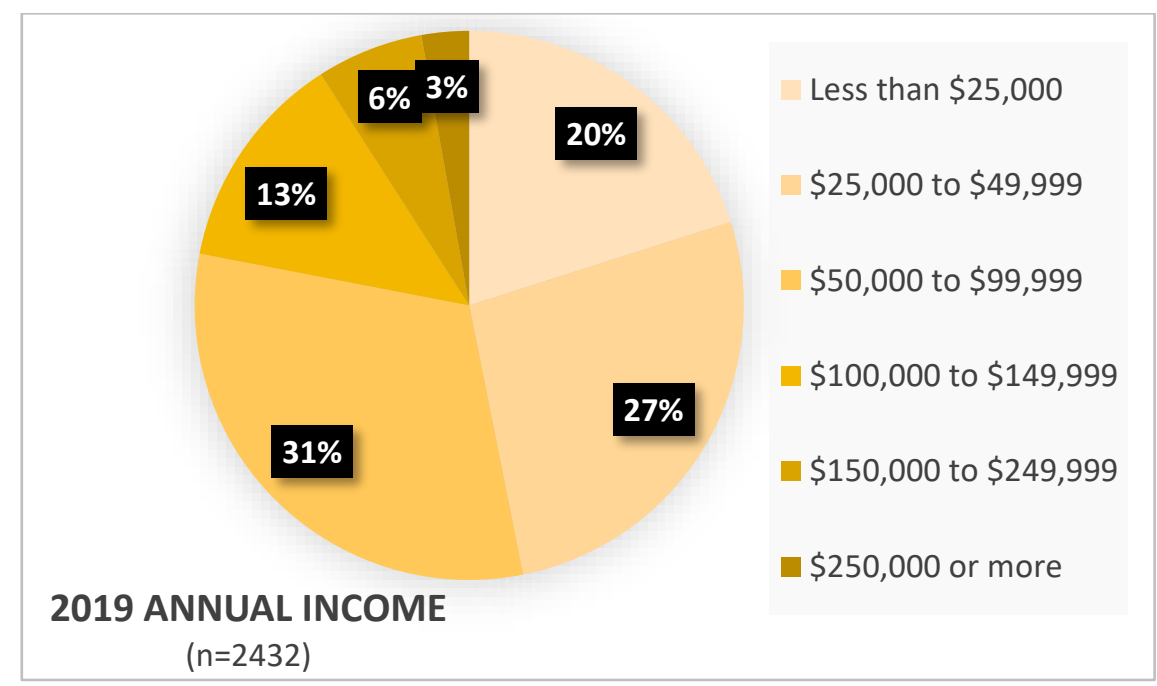

Figure 32. Annual Household Income

From a household perspective, it can be seen that a majority of the respondent households did not have young children (children under the age of 5). Presence of children in the households 
lightly improved as the age of the child went up but overall, the dataset did not include many households with multiple children under the age of 17. Looking at adult members, close to 30 percent of the households did not have adult members between the ages of 18 and 64 once again indicating the general trend of over representation among the older age groups. Close to 40 percent of the respondent households included at least one member with an underlying health condition (once again pointing to the older respondent cohort). Lastly, more than one-sixth of respondent households included members with no driver's licenses (for more information see Figure 33).

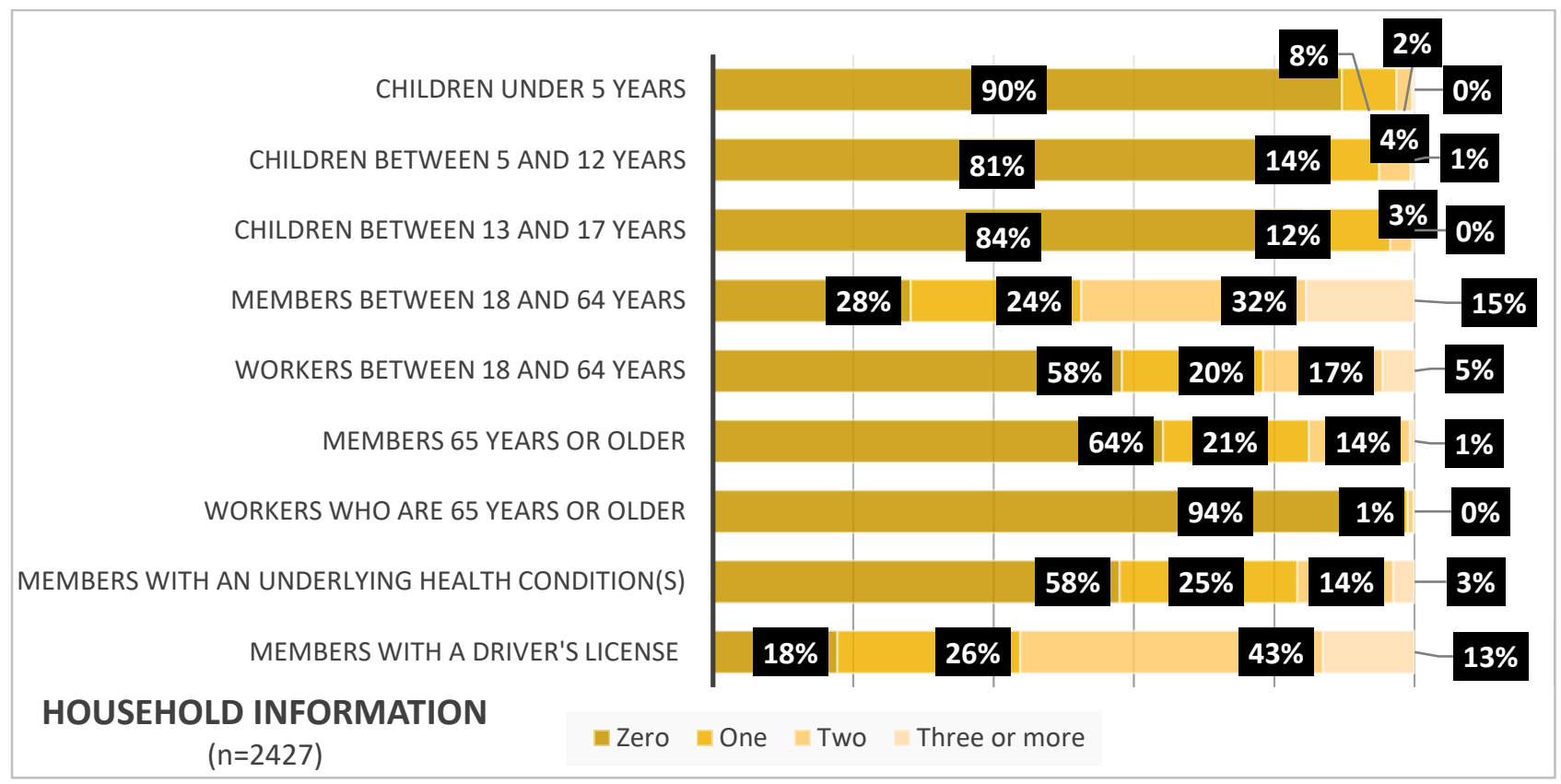

Figure 33. Respondent Household Information

\section{Vehicle Purchase Inventory}

Information was elicited from respondents on their vehicle purchase history. Since the COVID19 pandemic had extreme impacts on shared transportation modes (and systems), it would be worthwhile to investigate the influence of the pandemic on vehicle purchase behavior. The research team hypothesized that the nature of infection spread, and the corresponding challenges with embracing shared transportation in a post-pandemic world may have forced at least some people into making an unscheduled vehicle purchase to continue pursuing their trips and activities. To this end, respondents were asked about the presence of motorized vehicles in their household during the pre-pandemic era (Section B of the survey) and were then later on (in Section C) enquired about their recent vehicle purchase/sale since the onset of the pandemic. 


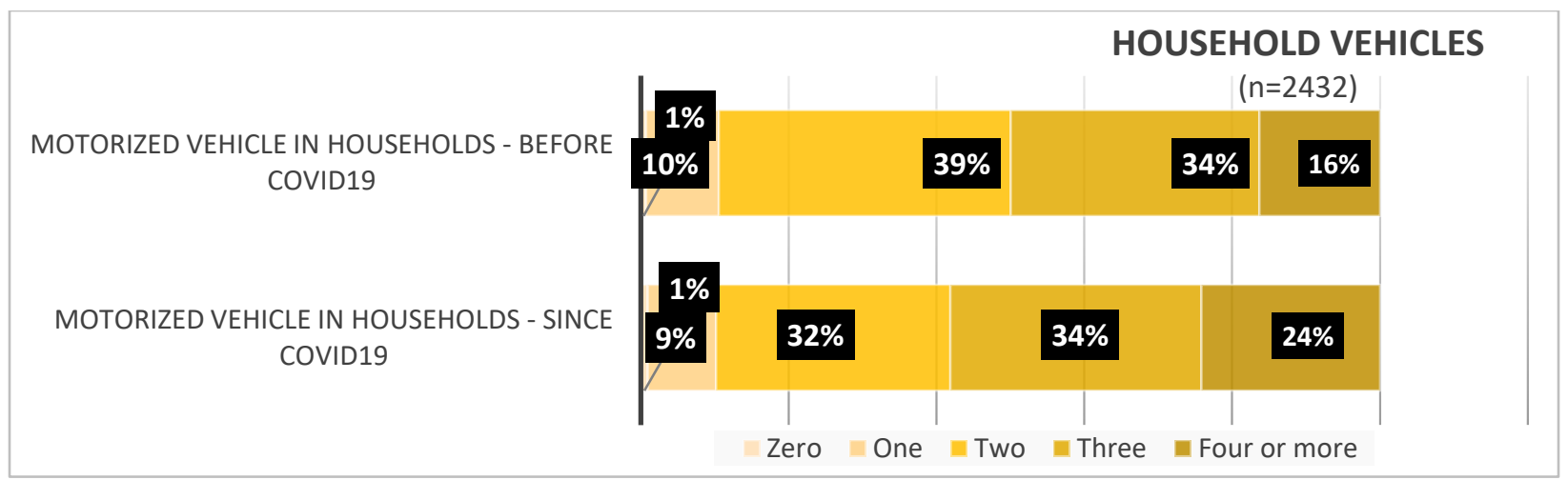

Figure 34. Household Vehicles - Before and During COVID-19

Results reveal an increasing trend in vehicle ownership (for the most cases) with more than 25 percent of the respondents purchasing/adding at least one vehicle to their household (refer to Figure 34 and Figure 35) since the onset of COVID-19. The reported risks associated with infection spread and the general reluctance among people to travel on shared transportation modes (for the fear of being in contact with others at close quarters) may have likely exacerbated vehicle purchases since the onset of the COVID-19 global pandemic.

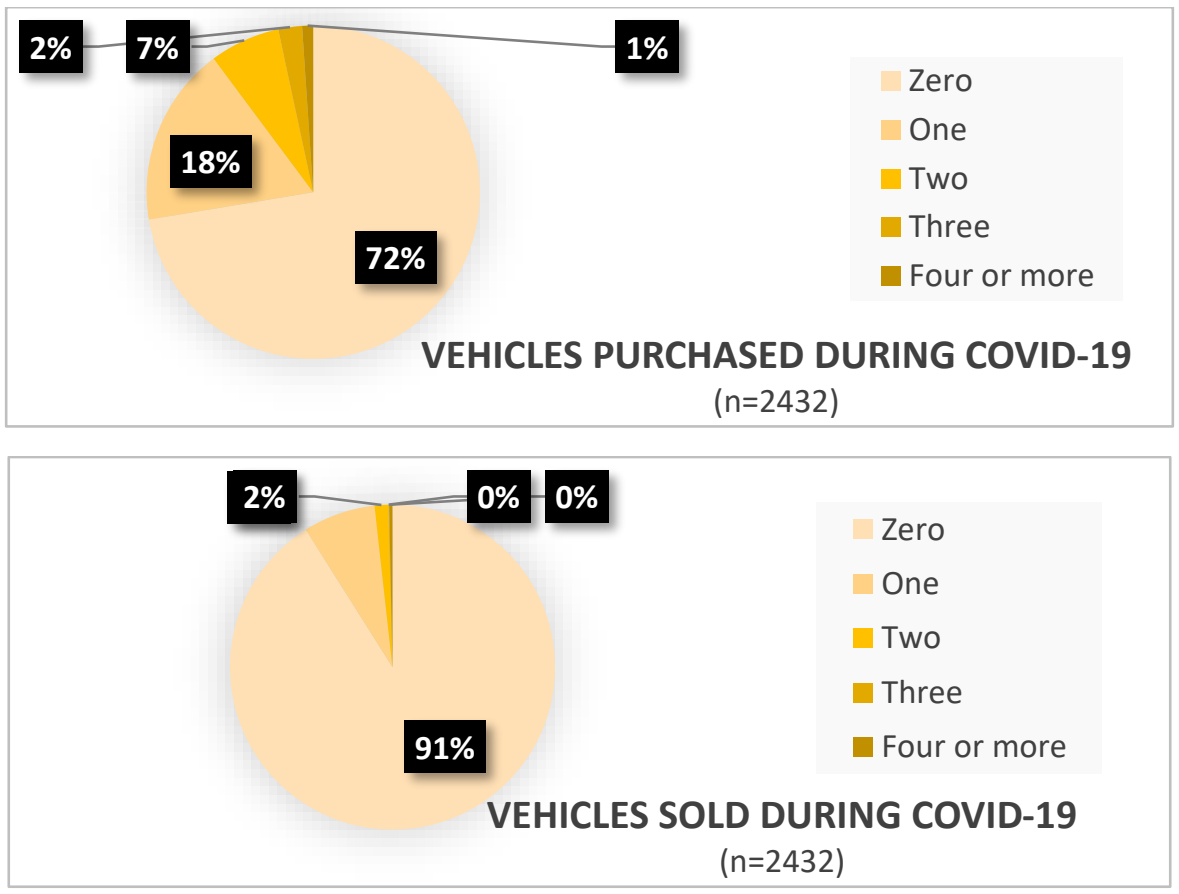

Figure 35. Vehicles Purchased and Sold During COVID-19

On the other hand, there also seems to be a minority of respondents ( 9 percent) who ended up relinquishing one or more of their vehicles in light of the pandemic. While this is a strict minority, this could be attributed to the potential of telecommuting longer-term, and the adoption of ICT services for substituting some/all trips and activities. It is not unfathomable for 
multi-vehicle households to be engaging in this kind of vehicle relinquishment at a time of substantially less vehicle usage (or even non-usage).

\section{Telecommuting}

The onset of the COVID-19 global pandemic has given rise to a more global (but perhaps forceful) acceptance of telecommuting by companies and organizations. Results from this stated preference show how there have been changes in telecommuting trends. Pre-pandemic, more than half of the surveyed respondents did not have "work from home" as an option in their professional settings. At the same time, it is also somewhat interesting to observe that almost one-fifth of the current sample (19 percent) work all days in a week from home (see Figure 36 below). As the research team does more investigations on this subject, it will give an opportunity to better understand these trends and check for its impacts on future activity engagement and travel behavior.

With the rapidly evolving health crisis, however, a higher share of respondents has been able to telecommute instead of being at work in-person most days of the week leading to a 100 percent increase in the number of people who work all work days in a week from home. When asked on how telecommuting trends would look like in a post-pandemic world, most respondents indicated greater likelihood of flexibility at work with potential increases in the interior categories (indicating their preference/ability to work some days of the work week from home) once COVID-19 was no longer a threat. It is also interesting how respondents feel that overall, telecommuting effects may come back to pre-COVID levels once the pandemic is no longer a threat. This has implications for planning and policymaking agencies that are at the heart of ringing in the changes to accommodate the new normal.

\section{Trip Making}

Based on the comprehensive review conducted in the first half of this report, it was seen that the COVID-19 pandemic had forced many changes to traditional trip-making characteristics and behaviors. The research team focused on this aspect as one of the key takeaways from the data collection instrument and elicited a lot of information. The key findings from this are as shown below.

\section{Commute Mode Choice}

Results from the stated preference survey conducted with Prime Panels show how commute mode choice has altered as a result of the COVID-19 pandemic. Drive alone is a predominant mode of choice for most respondents during their commute (see Figure 37). While those trends are likely to remain similar in a post-pandemic world, there is a lot more focus on the impact of the pandemic on shared mobility and shared transportation modes. Results reveal how public transit modes (both bus and rail) maybe the worst impacted mode as a consequence of the pandemic with the highest percentage decline in commute mode choice. Contrastingly, walk/bike modes have seen the highest percentage increase with more and more people expressing that they have been choosing said modes for the commute trips since the onset of the COVID-19 pandemic. 
WORK FROM HOME - BEFORE COVID-19

( $n=1101)$

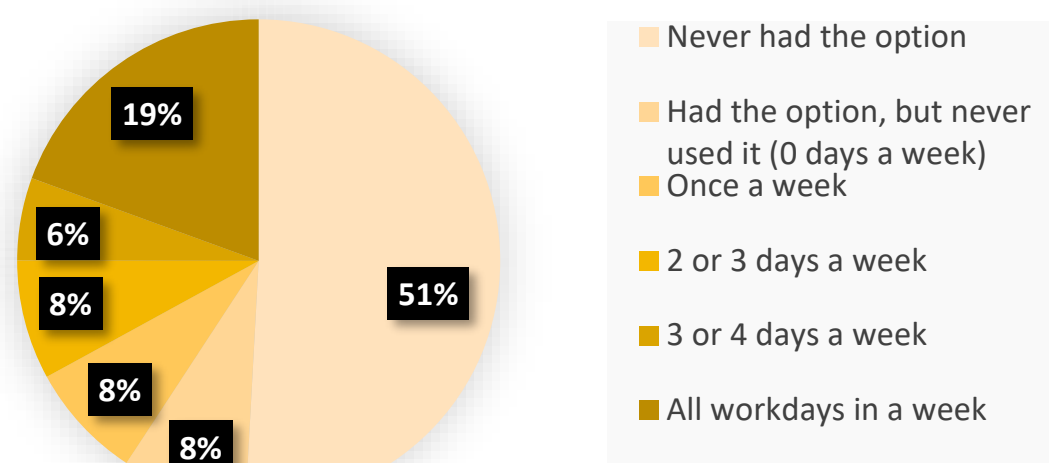

$8 \%$
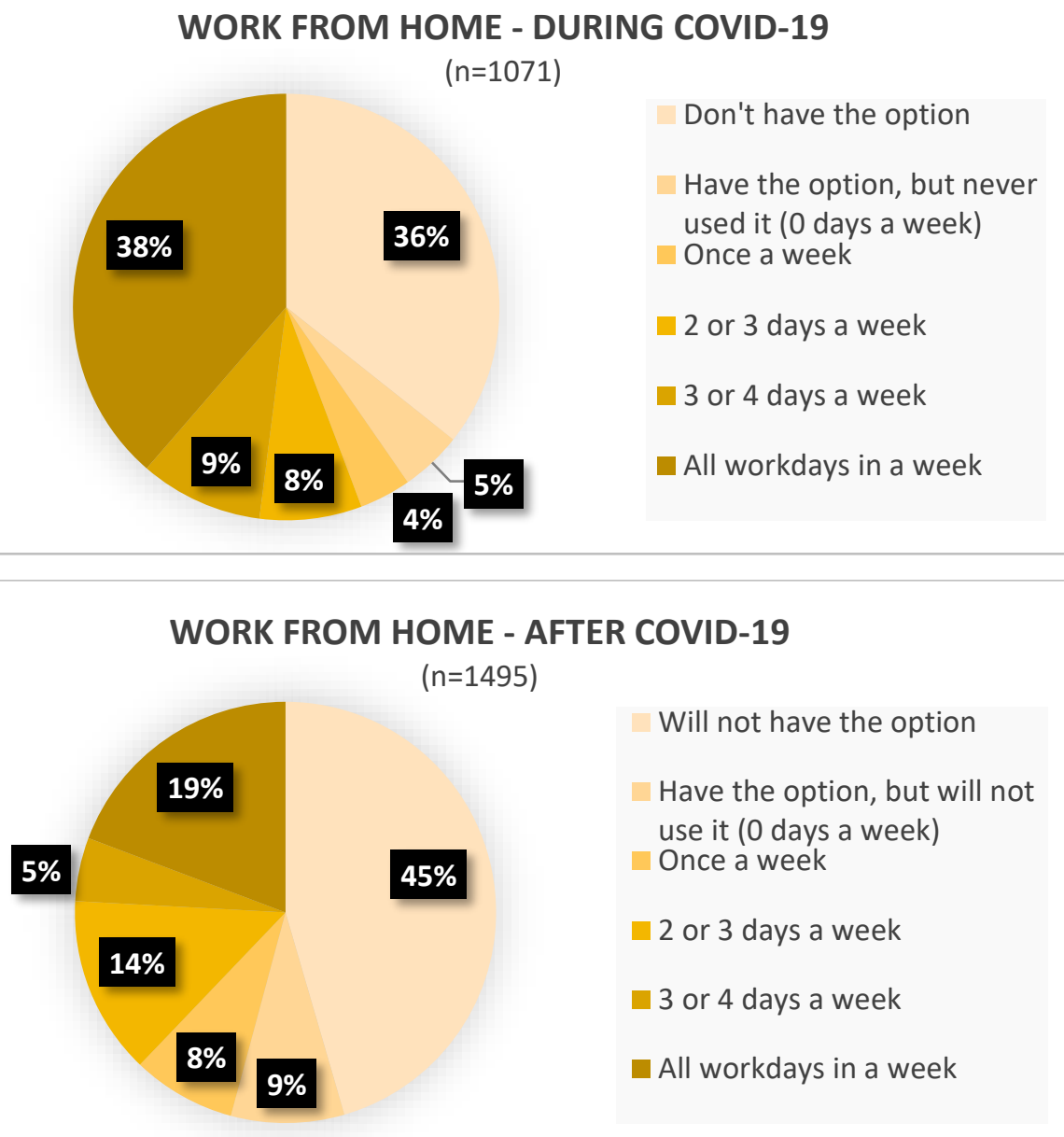

Figure 36. Work from Home - Before, During, and After COVID-19 

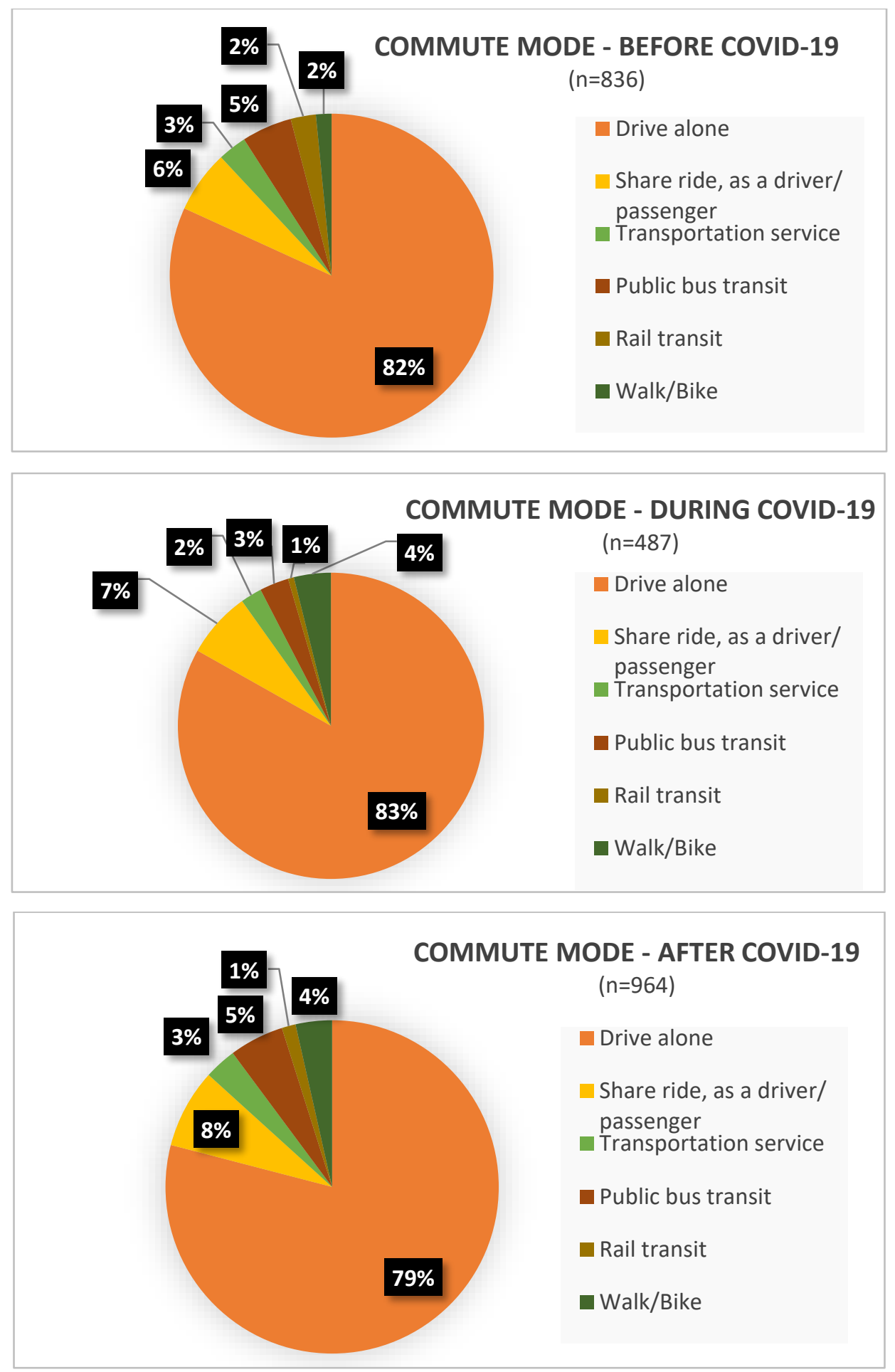

Figure 37. Commute Mode Choice - Before, During, and After COVID-19

Interestingly, when respondents were enquired about their preferences for commute modes once COVID-19 was no longer a threat, they felt that most transportation modes would make a course correction towards the pre-pandemic levels. Interestingly, respondents indicated 
that the use of walk and bike as a mode for commute trips may be more enhanced in a post pandemic world. This is very encouraging for cities that have engaged in reclaiming some space on the road for adding biking infrastructure. This is also in line with current discussions highlighting the relative preference for users towards biking or using bikesharing systems in cities across the United States of America.

\section{Shared Mobility Mode Choice in a Post-Pandemic World}

Results from the stated preference survey show the general skepticism in using many shared mobility modes once the COVID-19 pandemic is no longer a threat (see Figure 38).

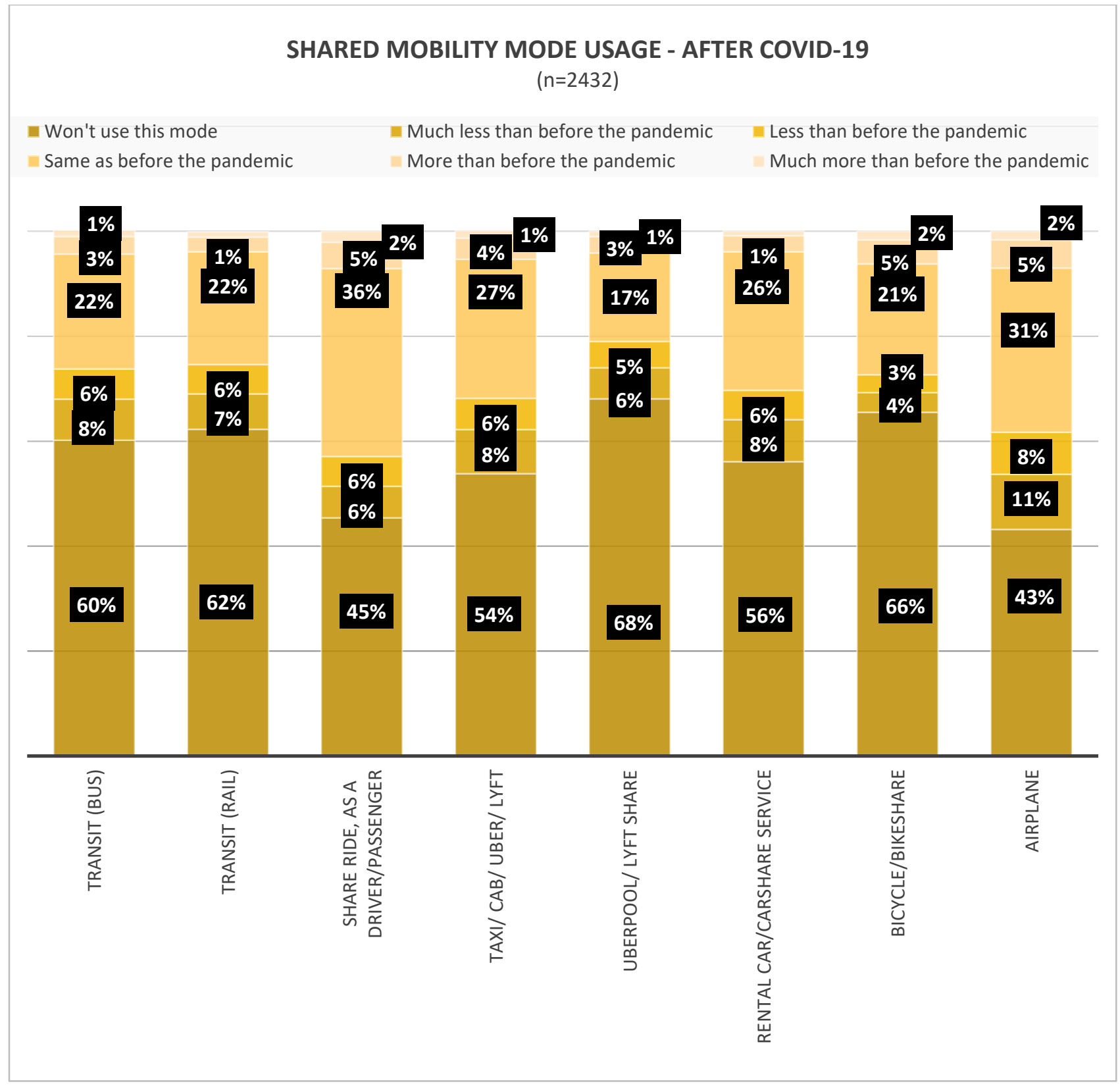

Figure 38. Shared Mobility Usage - After COVID-19 
When queried on their potential use of shared mobility modes post-pandemic, a significant share of respondents revealed that they would not be using modes such as UberPOOL/Lyft Share (68 percent), bicycle/bikeshare (65 percent), and public transit (60 percent). It is somewhat interesting to hear respondents say that they would be unwilling to bicycles/bikeshare, and we believe that this high rate may be attributed to the use of bikeshare as against personally owned bicycles. 40 percent of the respondents also stated that they will very likely use airplane for their trips, at the same rate as they did before the pandemic, if not more.

Past research on shared mobility preferences has shown how hygiene, and cleanliness play a big role in public preferences for using these modes. Shared mobility entities at the heart of providing pooled rides could perhaps consider other offerings that provide a safer means for people to travel for any/all trips. On the other hand, more than one-fifth of the respondents believe they would be able to use transit at least as much as they before the pandemic, for their trips.

\section{Shared Mobility Usage in the Era of the Pandemic}

This section outlines results on respondent opinions towards using shared mobility modes in the context of COVID-19. There has been a lot of discussion and discourse over the impact of the pandemic on shared transportation modes, therefore, this was considered an important takeaway from the current study. The research team tried to assess this phenomenon using several instruments. Results from this section are as shown in the illustrations below (Figure 39, Figure 40, and Figure 41).

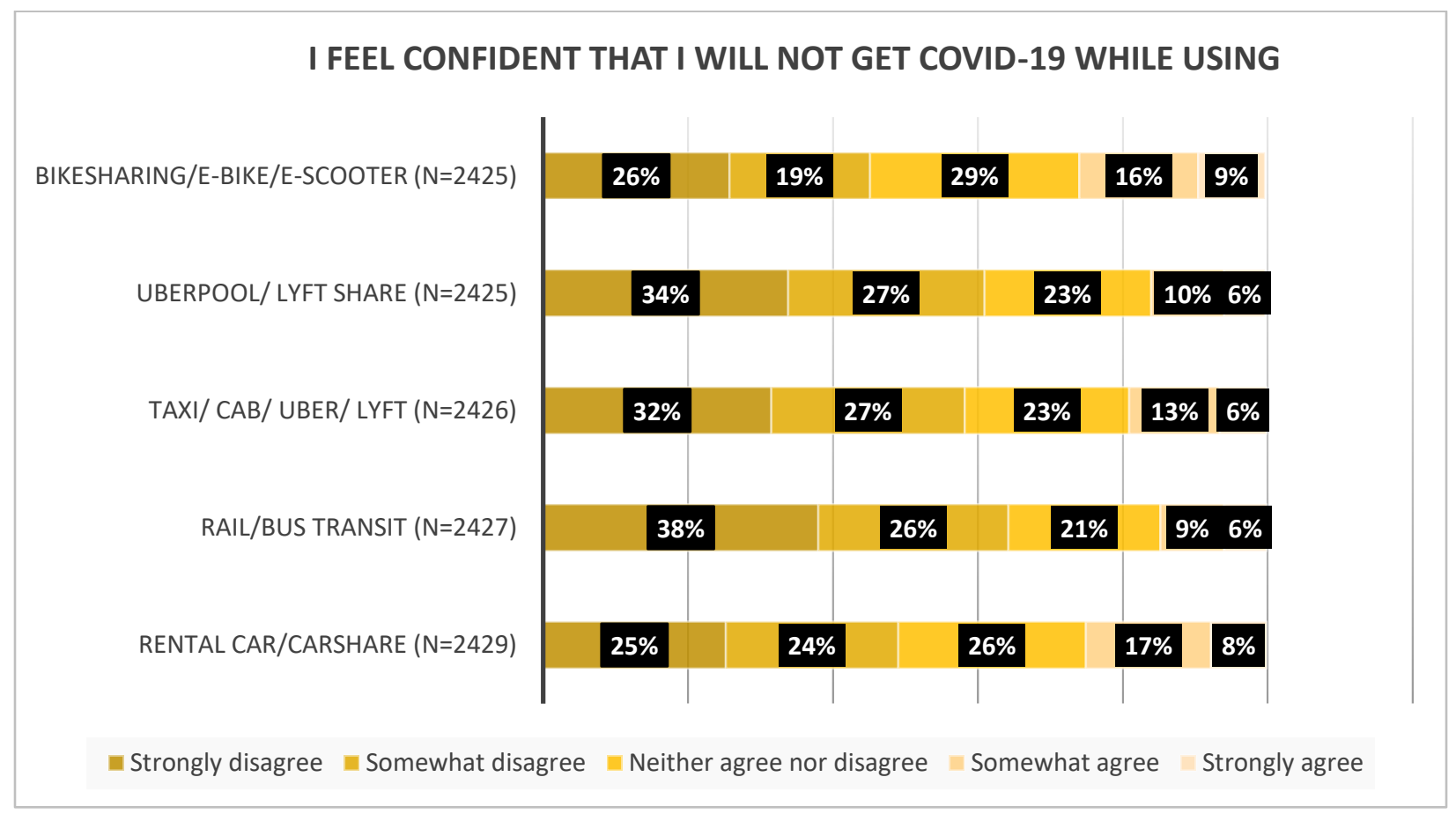

Figure 39. Respondent Opinion on Getting COVID-19 by Using Shared Mobility Modes 
When respondents were asked if they felt confident about not getting affected with COVID-19 while using shared mobility modes, a large majority of them (more than 60 percent) expressed some skepticism to use shared transportation modes such as rail/bus transit, UberPOOL/Lyft Share, and taxi/cab/Uber/Lyft (see Figure 39). Respondents felt most confident about using bikesharing/e-bikes/e-scooters ( 25 percent agreed that they felt confident), and rental car/carsharing systems (25 percent agreed that they felt confident).

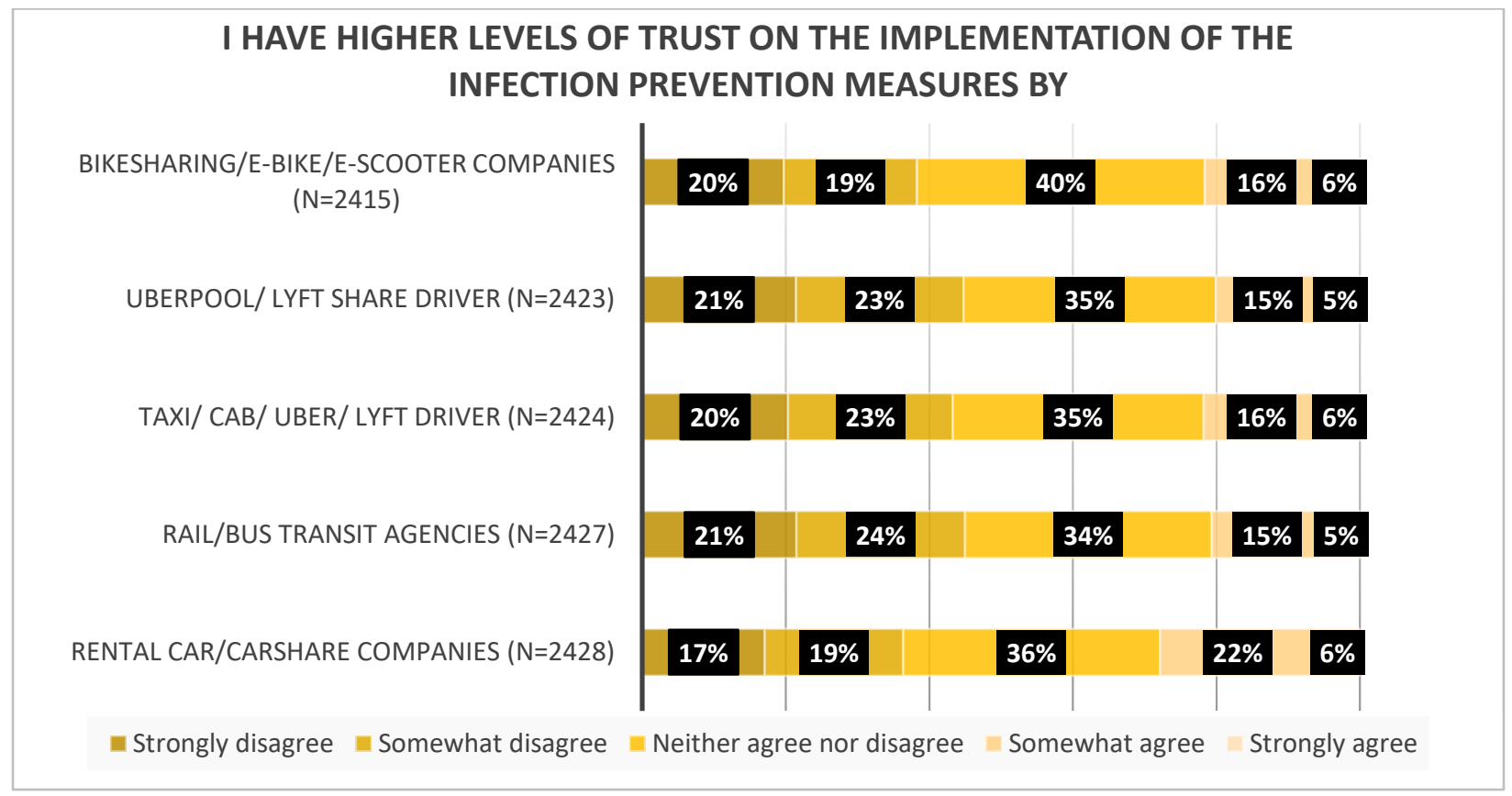

Figure 40. Respondent's Trust Level on Infection Prevention Measures Implemented by Shared Mobility Stakeholders

In order to understand people's opinions on the strategies employed by shared mobility companies since the COVID-19 pandemic, respondents were asked to indicate their level of agreement with a set of measures implemented by shared mobility stakeholders. For instance, several transit agencies have installed plexiglass partitions between the driver and passengers in buses (details on this can be seen in the first half of the report). This, while keeping the surfaces transparent, provides an added layer of safety from infection spread for transit users as well as the operator. Similar measures have been employed by shared mobility companies and recommended by companies such as Uber/Lyft to their drivers.

When respondents were asked whether such installations increase their confidence in using shared mobility modes, respondents revealed higher levels of trust on the part of rental car/carshare companies to strictly implement the above-mentioned infection prevention measures (see Figure 40). More than 40 percent of the respondents expressed skepticism about the implementation of these infection prevention measures on the part of transit agencies, and 
individual drivers (Taxi, cab, Uber, Lyft, Uber Pool, and Lyft Share). Also, interestingly, respondents feel the same kind of skepticism on the part of bikeshare/e-bike/e-scooter companies as well. This is worthy of investigation and may have to do with their relative inexperience using these modes as well. This may be directly correlated with their concerns on potentially interacting with other users on-board these fleets but is nonetheless an important predictor for understanding future efforts that should be undertaken by these entities in their quest to bring back the riders. It is also worth noting that significant shares of respondents are unsure about the effective implementation of infection prevention measures by shared mobility stakeholders. This needs to be viewed in caution, and shared mobility stakeholders should view these results as an indication of customer confidence and work towards better mitigating these circumstances.

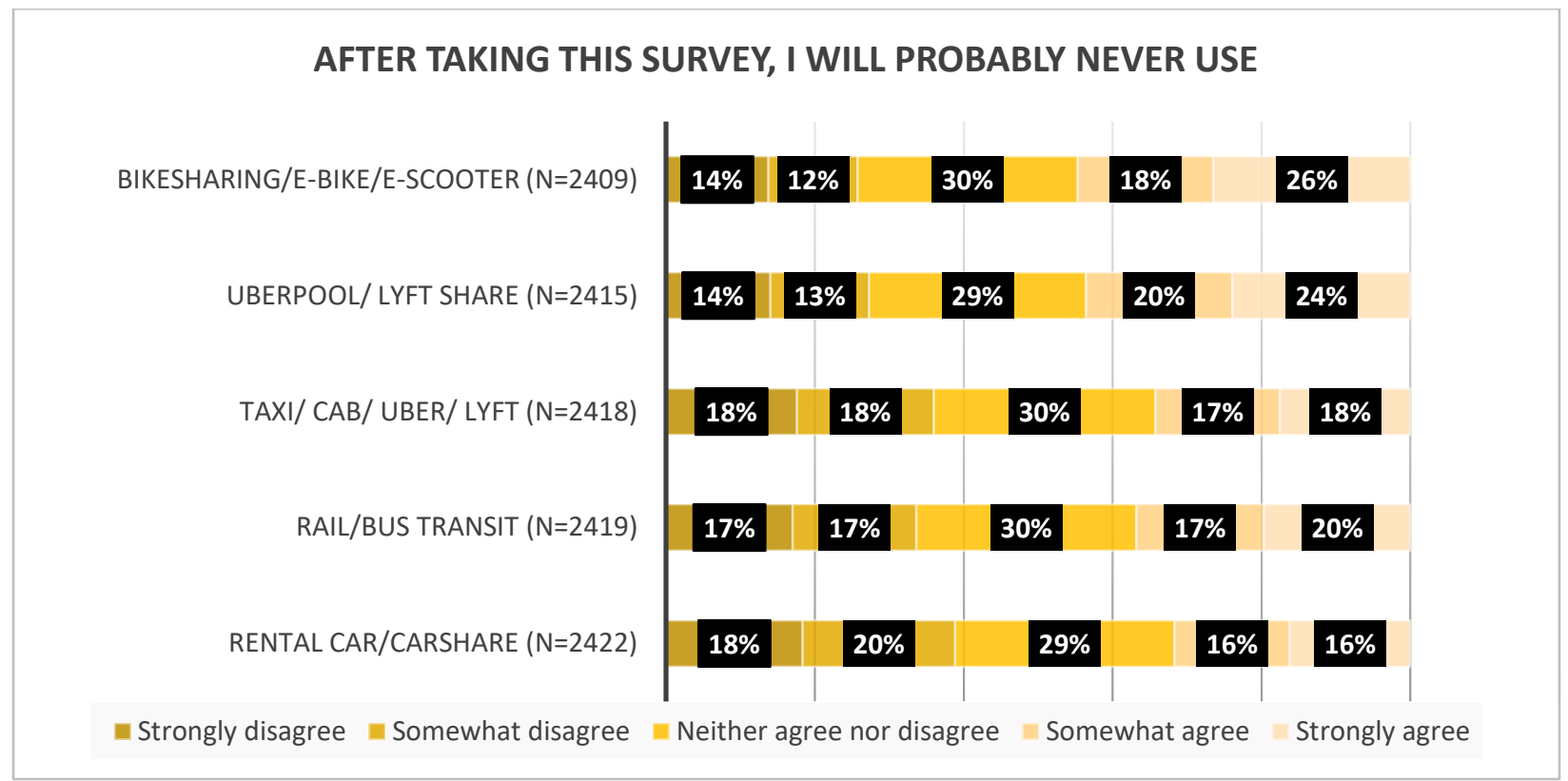

Figure 41. Respondent's Opinions on Using Shared Mobility Systems

Respondents were also asked if they would use shared mobility systems going forward. Figure 41 shows their opinions on this aspect. 44 percent of the respondents stated that they are probably never going to use Uber Pool/ Lyft Share. A similar share of respondents also had the same opinions regarding their use of bikesharing/e-bike/e-scooters. Once again, this is perhaps indicative of their relative inexperience using these systems for their trips and so is something that needs to be viewed with some caution.

\section{Activity Engagement and Participation}

COVID-19 has undoubtedly impacted our engagement and participation in a lot of activities, and it is therefore imperative to investigate how respondents perceived these impacts. Respondents were asked about a possible timeframe into the future where they felt they would be engaging in typical activities with the same intensity as they did before the COVID-19 pandemic. Figure 42 discusses the results from this investigation. 
Almost half of the respondents feel confident that they would engage in a road trip within the next 5 months. Considering that the data was collected in July-August 2020, it does seem like respondents feel that they would take a road trip within the end of the year. There is also a similar level of confidence about dining in regularly. At the point of writing this report, several states have already opened up and have ordered restaurants to resume dine-in service. Therefore, these results are in line with the current developments.

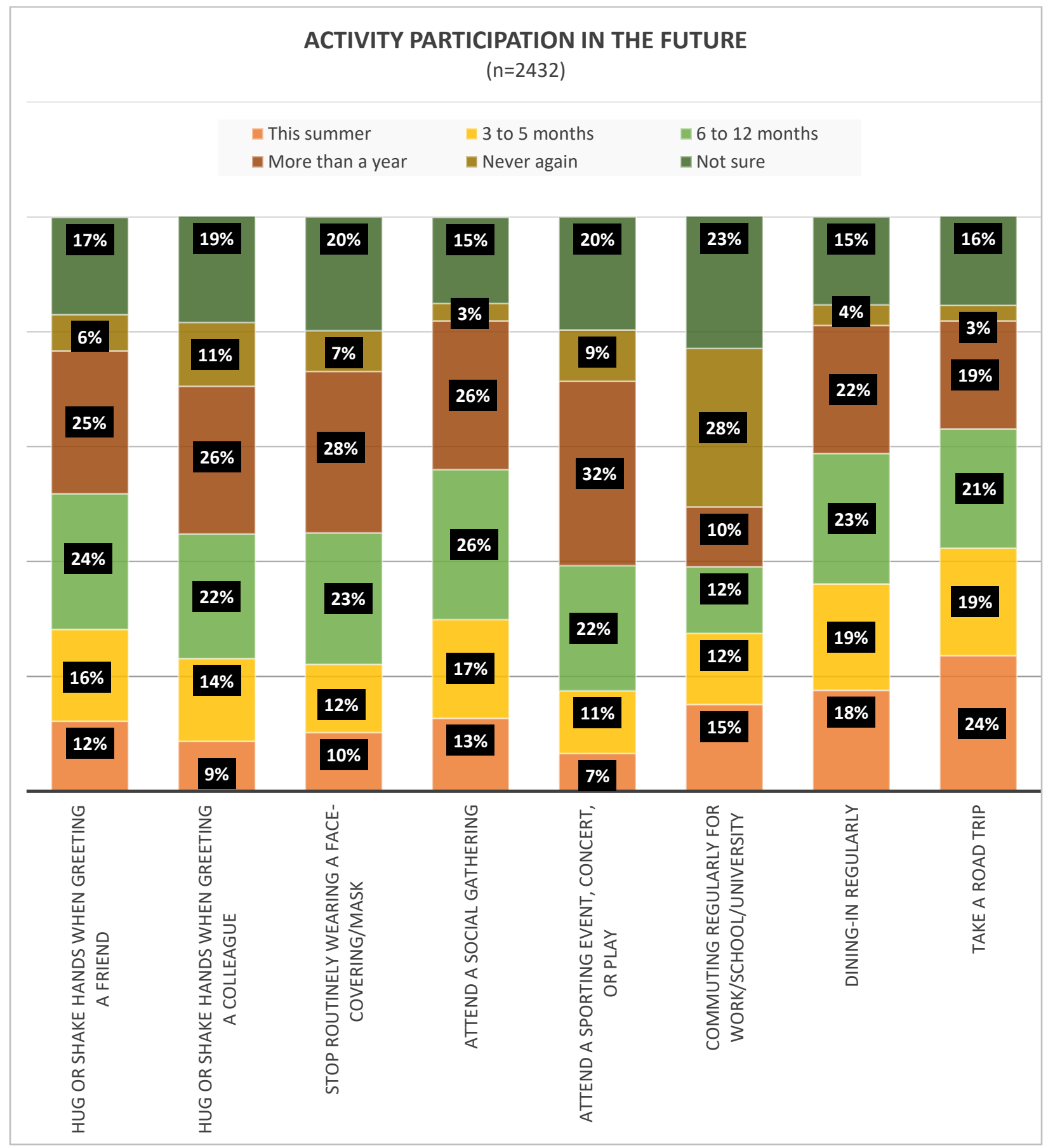

Figure 42. Future Activity Participation in the Era of the Pandemic 
As expected, respondents are apprehensive about taking part in activities that involve gathering around others (such as a sporting events, concerts, plays, or weddings) in close contact. Higher shares of respondent felt it would take upwards of a year for them to attend sporting events (32 percent), stop routinely wear facemasks ( 28 percent), and hug/shake hands with colleagues ( 26 percent), and attend social gatherings ( 26 percent). There also seems to be some uncertainty regarding going back to work in-person on a regular basis with a significantly high share of respondents ( 28 percent) citing that they were unsure. Considering that the data was collected in July-August 2020, a possible timeline by which respondents feel they can match most of their pre-COVID activity engagements would be the initial months of 2021 . 


\section{Summary \& Conclusions}

The COVID-19 pandemic has caused unprecedented disruption to businesses and daily lives. Various aspects of travel, transportation, and mobility were impacted since the outbreak of the virus. Despite the challenges associated with infection spread, transportation remains a crucial component for moving people during and after the pandemic. Critical also is the movement of essential workers and service providers who need to travel to serve their communities. As was the case with other sectors, transportation providers have struggled to keep services running in response to the massive drop in ridership levels. As a result, several providers adjusted their business models, and added new dimensions to their suite of offerings. For example, many shared mobility providers added food delivery services to compensate for the loss in ridership. At the individual level, to respect social distancing and protect themselves and families, most people have preferred using private vehicles rather than shared mobility systems, like public transportation and ride-sharing services.

The objective of this research study was to provide an enhanced understanding of the impacts of COVID-19 crisis on travel behavior, and shared mobility systems. A comprehensive web-based review was conducted to scope out all publicly available strategies that have been adopted by shared mobility providers/entities to combat the COVID-19 pandemic. The key findings from this exercise include the following:

- Public transit and ride-hailing ridership have greatly decreased during the lockdowns.

- Bike sharing operations have increased manifold and pose as a transportation mode with immense potential post-COVID-19.

- Robot taxis are identified as being critical to deal with future pandemics in order to facilitate social distancing and help with testing, deliveries, and other day-to-day operations.

Based on the web-review conducted, the research team believes that some changes that heralded as a consequence of the pandemic in the shared mobility space may remain long after the pandemic no longer remains a threat. They include:

- Stricter hygiene and cleaning standards for drivers and users of shared mobility systems

- Additional open space on the road for micromobility services

- Change in location decisions (residential and employment), vehicle occupancies, and vehicle miles traveled as a consequence of travel behavioral changes induced due to the pandemic

- Change in the future of shared mobility services with newer busines models and dimensions to supplement pre-COVID business models

- Renewed preference for ICT-enabled strategies, tele-activities, on-demand deliveries, and telecommuting 
In addition to the extensive web-based review, a comprehensive nationwide stated preference survey was conducted as part of this study. Some key findings are as follows:

- As people moved away from shared mobility systems, there was a greater tendency to purchase vehicles since the onset of the COVID-19 pandemic. This may lead to additional VMT if activity engagement, and trip-making characteristics go back to preCOVID levels.

- The return of telecommuting is here - while organizations may not always allow for work-from-home on all work days a week, U.S. adults feel that there is a greater likelihood for increased flexibility in working arrangements (in the case of those who can afford to work from home). Flexible work schedules may also have strategic advantages down the line for organizations.

- Trip making has changed significantly since the onset of the pandemic with public preferences against the use of shared transportation modes for the fear of infection spread. While this is the case right now, there is grounds to believe that some of the lost patronage on the part of shared transportation modes will be recovered once the COVID19 pandemic is no longer a threat. Results also show an increasing public preference for open transportation modes such as biking and walking.

- Shared mobility systems have been significantly impacted by the pandemic. Results from this study show that there is heightened concern or skepticism regarding the use of shared mobility modes that involve coming in close contact with other people (such as pooled ridehailing, and transit). Shared mobility providers may need to significantly invest in resources and add new dimensions to their operations in order to recover the lost patronage.

- Finally, there seems to be a growing understanding that some of the current constraints in terms of mobility, and activity engagement are likely to continue until at least the next six months to a year. While people may not involve themselves in all kinds of activities, comparable to pre-COVID levels, results from the stated preference survey show that some of the old habits/preferences may resume once the COVID-19 pandemic is no longer a threat.

\section{Future Work}

Considering the rapidly evolving nature of the pandemic, this study is by no means a finished product. As a result of this, there are several considerations for future work, and dimensions that this could take. First, the research team will be continuing with the comprehensive analysis of the stated preference survey. The stated preference survey captured a lot more information than was presented within the scope of this report. Of particular interest are potential changes in travel times, and their impact on travel behavior as a result of the adoption of ICT strategies such as telecommuting. Additionally, the survey also collected extensive information on respondent demographics from a nationwide panel of respondents. It will be worthwhile to investigate how 
varyingly some of the pandemic-induced impacts are spread spatially, and across the various socioeconomic classes.

Several respondents stated their preference to continue working-from-home more frequently than the pre-COVID levels. This has implications on a variety of lifestyle decisions including residential location, vehicle purchase (or relinquishment), e-commerce, and future travel behavior. The research team will be interested in investigating some of these potential impacts and their implications for future planning and policymaking. Shared mobility systems are also set for short- to medium-term impacts (in terms of ridership and patronage) based on the responses received in the stated preference survey. Follow-up studies could be conducted investigating how shared mobility providers are navigating the new normal, and what kind of policy-level implications the pandemic has had on their operations and future sustenance.

Another dimension would be to understand the scope of substitution to travel and its impacts on future travel behavior. Emerging transportation technologies such as automated vehicles are set to have short-, medium- and longer-term impacts on travel behavior and activity participation. Respondent opinions on autonomous vehicles in light of the COVID-19 pandemic have been collected and provide valuable insights on the impact of the pandemic on their intended adoption. Therefore, it may be worthwhile to investigate with this study (and future studies) on the impact of the pandemic on the future adoption, market penetration of these emerging transportation technologies. 


\section{References}

Acheampong, R. A., Siiba, A., Okyere, D. K., \& Tuffour, J. P. (2020). Mobility-on-demand: An empirical study of internet-based ride-hailing adoption factors, travel characteristics and mode substitution effects. Transportation Research Part C: Emerging Technologies, 115, 102638.

Annur, R., \& Ponnusamy, V. (2020). Information and Communication Technology (ICT) for Intelligent Transportation Systems (ITS). In Employing Recent Technologies for Improved Digital Governance (pp. 164-194). IGI Global.

Auto Rental. (2020). Eight Viewpoints on Mobility Post Coronavirus. Retrieved on 7/07/2020 from https://www.autorentalnews.com/355691/eight-viewpoints-on-mobility-postcoronavirus?utm_source=site\&utm_medium $=$ content\&utm_campaign=covid-19-resourcecenter

Ballotpedia. (2020). State government reopenings after coronavirus (COVID-19) lockdowns, 2020. Retrieved on $7 / 02 / 2020$ from https://ballotpedia.org/State_government_reopenings_after_coronavirus_(COVID19)_lockdowns,_2020 or https://ballotpedia.org/Status_of_lockdown_and_stay-athome_orders in response to the coronavirus_(COVID-19)_pandemic, 2020

Beedham, M. (2020). Survey: 39\% of people won't use ride-sharing services post coronavirus. Retrieved on 7/08/2020 from https://thenextweb.com/shift/2020/04/28/survey-39-peoplewont-use-ride-sharing-services-post-coronavirus-uber-lyft/

Bert,J., Schellong, D., Hagenmaier, M., Hornstein, D., Wegscheider,A. K., and Palme, T. (2020, June16). How COVID-19 Will Shape Urban Mobility. Retrieved on 7/08/2020 from https://www.bcg.com/publications/2020/how-covid-19-will-shape-urban-mobility

Bieser, J. C., \& Hilty, L. M. (2020). Conceptualizing the impact of information and communication technology on individual time and energy use. Telematics and Informatics, 49, 101375.

Bird Cities Blog. (2020, May 16). These 5 Cities are Getting Micromobility Right in Response to COVID-19. Retrieved on 7/23/2020 from https://www.bird.co/blog/these-5-cities-gettingmicromobility-right-response-covid-19/

Blanco, S. (2020, May 31). CDC Says Cars Are Better Than Mass Transit during COVID-19 Crisis. Retrieved on 7/08/2020 from https://www.caranddriver.com/news/a32723125/cdccars-safety-rules-coronavirus/

Bologna, C. (2020, June 15). Is It Safe To Take An Uber, Lyft Or Taxi During Coronavirus? What you should know about the risks of cabs or rideshare services amid the pandemic. Retrieved on 7/08/2020 from https://www.huffpost.com/entry/safe-uber-lyft-taxicoronavirus_1_5ee15384c5b6b74caf872e 23

Bond, S. (2020, May 18). Uber Cuts 3,000 More Jobs As Pandemic Squeezes Ride-Hailing. Retrieved on 7/08/2020 from https://www.kpbs.org/news/2020/may/18/uber-cuts-3000-morejobs-as-pandemic-squeezes/ 
Bruglieri, M., Bruschi, F., Colorni, A., Luè, A., Nocerino, R., \& Rana, V. (2015). A real-time information system for public transport in case of delays and service disruptions. Transportation Research Procedia, 10, 493-502.

Budnitz, H., Tranos, E., \& Chapman, L. (2020). Telecommuting and other trips: an English case study. Journal of Transport Geography, 85, 102713.

CDC. (2020). Coronavirus Disease 2019 (COVID-19): COVID-19 Employer Information for Office Buildings. Centers for Disease Control and Prevention (CDC). Retrieved on 7/29/2020 from https://www.cdc.gov/ coronavirus/2019-ncov/community/officebuildings.html

Cerqueira, E. D. V., Motte-Baumvol, B., Chevallier, L. B., \& Bonin, O. (2020). Does working from home reduce $\mathrm{CO} 2$ emissions? An analysis of travel patterns as dictated by workplaces. Transportation Research Part D: Transport and Environment, 83, 102338.

Center for Urban Transportation Research (CUTR). (2020). COVID-19 - Emergency Management Tips and Practices for Bus Transit Systems. Retrieved on 7/31/2020 from https://ftson.org/wp-content/uploads/2020/05/COVID-19-Emergency-Reponse-ResourceGuide-Final-06.05.20.pdf

Chicago Transit Authority (CTA). (2020). Coronavirus (COVID-19) info. Retrieved on 6/23/2020 from https://www.transitchicago.com/coronavirus/

Combs, T., Pardo, C.F., Streetplans, Epiandes, MobilityWorks, \& Datasketch (2020). The "Shifting Streets" Covid-19 mobility dataset. Available from http://pedbikeinfo.org/resources/resources_details.cfm?id=5235.

Cooperman, F. (2020). Ten cities that have redefined public transportation during COVID-19. Via Transportation. Retrieved on 6/23/2020 from https://www.masstransitmag.com/altmobility/shared-mobility/article/21135013/via-transportation-10-cities-that-have-redefinedpublic-transportation-during-covid19

de Haas, M., Faber, R., \& Hamersma, M. (2020). How COVID-19 and the Dutch 'intelligent lockdown'change activities, work and travel behaviour: Evidence from longitudinal data in the Netherlands. Transportation Research Interdisciplinary Perspectives, 100150.

De Vos, J. (2020). The effect of COVID-19 and subsequent social distancing on travel behavior. Transportation Research Interdisciplinary Perspectives, 100121.

DfT. (2020). Coronavirus (COVID-19): safer travel guidance for passengers. Department for Transport, United Kingdom. Retrieved on 7/27/2020 from https://www.gov.uk/guidance/coronavirus-covid-19-safer-travelguidance-for-passengers

Durán-Rodas, D., Chaniotakis, E., Wulfhorst, G., \& Antoniou, C. (2020). Open source datadriven method to identify most influencing spatiotemporal factors. An example of stationbased bike sharing. In Mapping the Travel Behavior Genome (pp. 503-526). Elsevier.

Dutzik, T. (2020). America on pause: Vehicle travel during COVID-19 and what comes next. Retrieved on 6/23/2020 from https://uspirg.org/blogs/blog/usp/america-pause-vehicle-travelduring-covid-19-and-what-comes-next

Elldér, E. (2020). Telework and daily travel: New evidence from Sweden. Journal of Transport Geography, 86, 102777. 
Ellison, S. (2020, April 20). Uber Launches Two New Delivery Services in Response to COVID19. Retrieved on 7/08/2020 from https://www.nbcbayarea.com/news/local/uber-launchestwo-new-delivery-services-in-response-to-covid-19/2276054/

Federal Transit Administration (FTA). (2020). Shared Mobility Definitions. Retrieved on 7/08/2020 from https://www.transit.dot.gov/regulations-and-guidance/shared-mobilitydefinitions

Ferenchik, M. (2020). OH: Scooters return to Columbus amid concerns over cleaning. The Columbus Dispatch (TNS). https://www.masstransitmag.com/alt-mobility/sharedmobility/bicycle-scooter-sharing/news/21137523/oh-scooters-return-to-columbus-amidconcerns-over-cleaning

Fox Rent A Car. (2020). Move Safely With Fox Rent A Car. Retrieved on 7/06/2020 from https://www.foxrentacar.com/en/covid-19-information.html

Fu, X. M. (2020). Does heavy ICT usage contribute to the adoption of ride-hailing app?. Travel Behaviour and Society, 21, 101-108.

Gershman, J. (2020). A Guide to State Coronavirus Reopenings and Lockdowns. Wall Street Journal. Retrieved on 08/04/2020 from https://www.wsj.com/articles/a-state-by-state-guideto-coronavirus-lockdowns-11584749351

Hawkins, A. J. (2020, May 13). Uber's response to COVID-19: face masks, selfies, and fewer people in the car. Retrieved on 7/06/2020 from https://www.theverge.com/2020/5/13/21257432/uber-face-mask-driver-rider-require-selfiesmaximum-passengers\#comments

Heineke,K.; Kloss, B. and Scurtu, D. (2020, July 16 ). The future of micromobility: Ridership and revenue after a crisis. Retrieved on 7/23/2020 from https://www.mckinsey.com/industries/automotive-and-assembly/our-insights/the-future-ofmicromobility-ridership-and-revenue-after-a-crisis\#0

Jacksonville Regional Transportation Center (JRTC). (2020). A New Home for JTA in the Heart of LaVilla. Retrieved on 7/20/2020 from https://jrtc.jtafla.com/

Jamal, S., \& Habib, M. A. (2020). Smartphone and daily travel: How the use of smartphone applications affect travel decisions. Sustainable Cities and Society, 53, 101939ISSN 22106707 https://doi.org/10.1016/j.scs.2019.101939.

JPMorgan Chase \& Co. (2020). The Initial Household Spending Response to COVID-19. Retrieved on $6 / 23 / 2020$ from https://institute.jpmorganchase.com/institute/research/household-income-spending/initialhousehold-spending-response-to-covid-19

Laser, G. (2020). Covid-19, an Unexpected Turn on the Mobility Road and Why It's a Turn for the Better. Retrieved on 7/08/2020 from https://www.calcalistech.com/ctech/articles/0,7340,L-3809872,00.html

Lazo, L. (2020). Another casualty of the coronavirus pandemic: The taxi industry. Retrieved on 9/28/2020 from https://www.washingtonpost.com/local/trafficandcommuting/anothercasualty-of-the-coronavirus-pandemic-the-taxi-industry/2020/04/25/f96a085a-8009-11ea$\underline{\text { 8013-1b6da0e4a2b7_story.html }}$ 
Lee, Y., \& Circella, G. (2019). Chapter five - ICT, millennials' lifestyles, and travel choices. In Eran ben-Elia (Ed.), Advances in transport policy and planning (Vol. 3, pp. 107-141, ISSN 2543-0009, ISBN 9780128162132). Academic. https://doi.org/10.1016/bs.atpp.2019.08.002.

Lee, J. C., Mervosh, S., Avila, Y., Harvey, B., and Matthews, A. L. (2020). See How All 50 States Are Reopening (and Closing Again). The New York Times. Retrieved on 7/02/2020 from https://www.nytimes.com/interactive/2020/us/states-reopen-map-coronavirus.html

Li, Xun, Lin, Qinyun, and Kolak, Marynia. (2020). The U.S. COVID-19 Atlas, 2020. University of Chicago. Retrieved on 7/10/2020 from https://geodacenter.github.io/covid/map.html

Lee, J. C., Mervosh, S., Avila, Y., Harvey, B., and Matthews, A. L. (2020). See How All 50 States Are Reopening (and Closing Again). The New York Times. Retrieved on 7/02/2020 from https://www.nytimes.com/interactive/2020/us/states-reopen-map-coronavirus.html

Markets and Markets. (2020, April). COVID-19 Impact on Ride Sharing Market by Service Type (E-Hailing, Car Sharing, Car Rental, Station-Based Mobility), Data Service (Information, Navigation, Payment) and Region - Forecast to 2021. Retrieved on 7/07/2020 from https://www.marketsandmarkets.com/Market-Reports/covid-19-impact-on-ride-sharingmarket-15098676.html

Mass Transit. (2020). Public Transportation Navigates the New Normal. Graffiti Shield Solution, Anti-Microbial Film Protection. Retrieved on 6/24/2020 from https://www.nxtbook.com/endeavor/masstransit/june2020/index.php\#/p/18

Molloy, J., T. Schatzmann, B. Schoeman, C. Tchervenkov, B. Hintermann, and K. W. Axhausen. (2020). Observed impacts of COVID-19 on travel behaviour in Switzerland based on a large GPS panel. Working paper. IVT, ETH Zurich.

National Academies of Sciences, Engineering, and Medicine. (2016). Shared Mobility and the Transformation of Public Transit. Washington, DC: The National Academies Press. https://doi.org/10.17226/23578

Naka, M. (2020, April 06). COVID-19 Reveals How Micromobility Can Build Resilient Cities. Retrieved on 7/23/2020 from https://nextcity.org/daily/entry/covid-19-reveals-howmicromobility-can-build-resilient-cities

Northwestern University Transportation Center (NUTC) (2020, July 09). NUTC AVR - Cities 1 and 2 - "The Vital Role of Public Transportation in Reopening Our Cities". [Webcast/Round table discussion] https://www.youtube.com/watch?v=sE6UTf8rgkI

Occupational Safety and Health Administration (OSHA). (2020). COVID-19 Guidance for Rideshare, Taxi, and Car Service Workers. Retrieved on 7/07/2020 from https://www.osha.gov/Publications/OSHA4021.pdf

Pernot, D. (2020). Internet shopping for Everyday Consumer Goods: An examination of the purchasing and travel practices of click and pickup outlet customers. Research in Transportation Economics, 100817.

Premack, R. (2020, June 04). CDC says Americans should ditch public transit for cars because of the coronavirus, and it could push emissions higher than ever. Business Insider. Retrieved on 7/07/2020 from https://www.businessinsider.com/cdc-cars-over-mass-transit-amidcoronavirus-2020-6 
Rivoli, D. (2020, March 18). Coronavirus Hits Taxi Industry Already Reeling From E-Hail Apps. Retrieved on 7/08/2020 from https://www.ny1.com/nyc/allboroughs/news/2020/03/18/coronavirus-hits-taxi-industry-already-reeling-from-e-hail-apps

Ryu, S., Choi, K., \& Cho, D. (2020). A behaviour-based typology of travellers using an online travel marketplace. Current Issues in Tourism, 1-19.

Sabouri, S., Brewer, S., \& Ewing, R. (2020). Exploring the relationship between ride-sourcing services and vehicle ownership, using both inferential and machine learning approaches. Landscape and Urban Planning, 198, 103797.

Sixt. (2020). Stay Safe and Travel Flexibility with Sixt Retrieved on 7/07/2020 from https://www.sixt.com/magazine/news/current-travel-information/

Staff, A. (2020). Small Car Rental Companies Pivot to New Business. Retrieved on 7/07/2020 from https://www.autorentalnews.com/10118891/small-car-rental-companies-pivot-to-newbusiness?utm_source=site\&utm_medium =content\&utm_campaign=covid-19-resource-center

TBRC. (2020). Impact of COVID-19 on the Taxi and Limousine Services Market- TBRC Report Insights. Retrieved on 9/28/2020 from https://www.prnewswire.com/news-releases/impactof-covid-19-on-the-taxi-and-limousine-services-market--tbrc-report-insights-301054745.html

Tam, K., and Melgar, L. (2020). A Guide to State Coronavirus Reopenings and Lockdowns. Wall Street Journal. Retrieved on 07/02/2020 from https://www.wsj.com/articles/a-state-bystate-guide-to-coronavirus-lockdowns-11584749351

Tang, L., Ho, C. Q., Hensher, D., \& Zhang, X. (2020). Demand for travel information: what, when and how much is required by urban travellers.

Taylor, B., and Wasserman, J. (2020). For the Press: Transportation, Coronavirus and COVID19. Institute of Transportation Studies. https://www.its.ucla.edu/for-the-press/transportationcoronavirus-covid19/

Taylor, E. (2020). How Will COVID-19 Impact New York Travel and Tourism in 2020? Drive Research. Retrieved on 6/23/2020 from https://www.driveresearch.com/market-researchcompany-blog/how-will-covid-19-impact-new-york-travel-and-tourism-in-2020/

Theen, A. (2020). OR: E-scooter companies ditch Portland, ridership plummets amid coronavirus pandemic. oregonlive.com (TNS). Retrieved on 6/24/2020 from https://www.masstransitmag.com/alt-mobility/shared-mobility/bicycle-scootersharing/news/21132707/or-escooter-companies-ditch-portland-ridership-plummets-amidcoronavirus-pandemic

Tierney, B. (2020). Insurance and Car Rental: Don't Let a Crisis Go to Waste. Retrieved on 7/07/2020 from https://www.autorentalnews.com/356406/insurance-and-car-rental-dont-leta-crisis-go-to-waste?utm_source=site \&utm_medium=content \&utm_campaign=covid-19resource-center

Thompson, C. (2020). COVID-19 pandemic forces dramatically lower rental car prices. KOMO News. Retrieved on 7/06/2020 from https://komonews.com/news/consumer/covid-19pandemic-forces-dramatically-lower-rental-car-prices

Transit. (2020). Helping agencies respond to coronavirus. Retrieved on 7/29/2020 from https://transitapp.com/coronavirus-response and 
https://docs.google.com/spreadsheets/d/1sdsvcFOzcpZ97uj-oUtS6yRqlRWjuD5H3FU_VF9c1k/edit\#gid=1041304419

TransLink. (2020). Coronavirus (COVID-19). Retrieved on 7/21/2020 from https://new.translink.ca/rider-guide/coronavirus-precautions

Transport for London (TfL). (2020). Coronavirus. Retrieved on 7/21/2020 from https://tfl.gov.uk/campaign/coronavirus?intcmp $=63016$

Uber. (2020). Committed to helping. Retrieved on 9/27/2020 from https://www.uber.com/us/en/coronavirus/

Union Internationale des Transports Publics or International Association of Public Transport (UITP). (2020). Public Transport and COVID-19. Retrieved on 7/21/2020 from https://www.uitp.org/public-transport-and-covid-19

University of Chicago. (2020). Interactive map of daily new confirmed COVID-19 case counts by county. Retrieved on 7/10/2020 from https://geodacenter.github.io/covid/map.html

Varghese, V., \& Jana, A. (2019). Interrelationships between ICT, social disadvantage, and activity participation behaviour: A case of Mumbai, India. Transportation Research Part A: Policy and Practice, 125(2019), 248-267ISSN 0965-8564 https://doi.org/10.1016/j.tra.2018.06.009.

Walters, N. (2020). TX: Unlike Lyft and Uber, Dallas-based Alto was built for a global pandemic. The Dallas Morning News (TNS). Retrieved on 6/24/2020 from https://www.masstransitmag.com/alt-mobility/shared-mobility/news/21141402/tx-unlikelyft-and-uber-dallasbased-alto-was-built-for-a-global-pandemic

Washington Metropolitan Area Transit Authority (WMATA). (2020). Metro and Covid-19: Steps we've taken. Retrieved on 7/20/2020 from https://www.wmata.com/service/covid19/COVID-19.cfm

Watkins, K. E., Ferris, B., Borning, A., Rutherford, G. S., \& Layton, D. (2011). Where Is My Bus? Impact of mobile real-time information on the perceived and actual wait time of transit riders. Transportation Research Part A: Policy and Practice, 45(8), 839-848.

Wilson, K. (2020). COVID19 Legacy: The Death of the Avoidable Car Trip? Retrieved on 6/23/2020 from https://usa.streetsblog.org/2020/03/23/covid19-legacy-the-death-of-theavoidable-car-trip/

Wood, L. (2020). COVID-19 Impact on ICT Industry (2Q 2020 Edition) -

ResearchAndMarkets.com. Retrieved on 6/24/2020 from https://www.businesswire.com/news/home/20200414005979/en/COVID-19-Impact-ICTIndustry-2Q-2020-Edition

Wu, J., Smith, S., Khurana, M., Siemaszko, C., and DeJesus-Banos, B. (2020, April 29). Stay-athome orders across the country. What each state is doing — or not doing - amid widespread coronavirus lockdowns. NBC News. Retrieved on 8/04/2020 from https://www.nbcnews.com/health/health-news/here-are-stay-home-orders-across-countryn1168736\#alabama

Yang, Y., Li, S., Zhang, K., Xiang, X., Li, Z., Ahn, S., \& Murphy, J. (2020). How the Daily Smartphone is Associated with Daily Travel, Physical Activity, and Self-Perceived Health: 
Evidence From 2017 National Household Travel Survey. Journal of Aging and Physical Activity, 1(aop), 1-9. 


\section{Appendix A: Shared Mobility Characteristics}

Table A 1. Examples of Shared Mobility Characteristics

\begin{tabular}{|c|c|c|c|c|c|c|c|c|}
\hline Region & $\begin{array}{l}\text { Metro } \\
\text { Area } \\
\text { Pop. } \\
\text { (millions) }\end{array}$ & $\begin{array}{l}\text { Core City } \\
\text { Pop. } \\
\text { (millions) }\end{array}$ & $\begin{array}{l}\text { Urbanized } \\
\text { Area } \\
\text { (sq. mi.) }\end{array}$ & $\begin{array}{l}\text { Metro Area } \\
\text { Solo Auto } \\
\text { Commute \%; } \\
\text { Avg. Household } \\
\text { Vehicle Count } \\
\end{array}$ & $\begin{array}{l}\text { Carshare } \\
\text { Operators; Vehicle } \\
\text { Count; Total Cars } \\
\text { per 10K Core Pop. }\end{array}$ & $\begin{array}{l}\text { Bikeshare Oper at ors; } \\
\text { Bike and Station Count; } \\
\text { Total Bikes per 10K } \\
\text { Core Pop. }\end{array}$ & $\begin{array}{l}\text { Ridesourcing and } \\
\text { Microtransit } \\
\text { Providers; Launch } \\
\text { Year } \\
\end{array}$ & $\begin{array}{l}\text { Transit Systems: Total } \\
\text { Annual Unlinked Trips } \\
\text { (millions); Annual Trips per } \\
\text { Capita (p.c) }\end{array}$ \\
\hline $\begin{array}{l}\text { Austin-Round } \\
\text { Rock, TX }\end{array}$ & 1.78 & 0.91 & 523 & $81.4 \% ; 1.77$ & $\begin{array}{l}\text { Car2Go (one-way), } \\
\text { Zipcar (traditional); } \\
381 \text { cars; } 4.2 / 10 \mathrm{~K}\end{array}$ & $\begin{array}{l}\text { Austin BCycle; } \\
375 \text { bikes, } 46 \text { stations; } \\
4.1 / 10 \mathrm{~K}\end{array}$ & $\begin{array}{l}\text { Lyft, Uber; } \\
2014\end{array}$ & $\begin{array}{l}\text { Capital Metropolitan Transit } \\
\text { Authority (CapMetro); } \\
\text { 36.4; } 26.7 \text { p.c. }\end{array}$ \\
\hline $\begin{array}{l}\text { Boston- } \\
\text { Cambridge- } \\
\text { Newton, MA-NH }\end{array}$ & 4.60 & 0.66 & 1873 & $72.0 \% ; 1.58$ & $\begin{array}{l}\text { Enterprise, Zipcar } \\
\text { (traditional); } \\
1265 \text { cars; } 19.46 / 10 \mathrm{~K}\end{array}$ & $\begin{array}{l}\text { Hubway; } \\
1300 \text { bikes, } 139 \text { stations; } \\
19.8 / 10 \mathrm{~K}\end{array}$ & $\begin{array}{l}\text { Lyft, Uber; } \\
2012 \\
\text { Bridj (microtransit); } \\
2014 \\
\end{array}$ & $\begin{array}{l}\text { Mass. BayTrans portation } \\
\text { Authority (MBTA); } \\
\text { 395.3; } 94.5 \text { p.c. }\end{array}$ \\
\hline $\begin{array}{l}\text { Chicago- } \\
\text { Naperville-Elgin, } \\
\text { IL-IN-WI }\end{array}$ & 9.49 & 2.72 & 2443 & $74.1 \% ; 1.62$ & $\begin{array}{l}\text { Enterprise, Zipcar } \\
\text { (traditional); } \\
790 \text { cars; } 2.9 / 10 \mathrm{~K} \\
\left.\text { Getaround ( } \mathrm{p} 2 \mathrm{p}^{*}\right) \\
120 \text { cars; } 0.4 / 10 \mathrm{~K}\end{array}$ & $\begin{array}{l}\text { Divvy; } \\
4760 \text { bikes, } 476 \text { stations; } \\
17.5 / 10 \mathrm{~K}\end{array}$ & $\begin{array}{l}\text { Lyft, Uber; } \\
2013 \\
\text { Via (microtransit); } \\
2015\end{array}$ & $\begin{array}{l}\text { Chicago Transit Authority } \\
\text { (CTA); } \\
529.2 ; 61.5 \text { p.c. } \\
\text { NE III. Regional Commuter } \\
\text { Railroad (Metra); } \\
73.6 ; 8.6 \text { p.c. } \\
\text { Pace Suburban Bus; } \\
\text { 35.9; } 4.2 \text { p.c. } \\
\text { Total: } 638.7 ; 74.2 \text { p.c. }\end{array}$ \\
\hline $\begin{array}{l}\text { Los Angeles-Long } \\
\text { Beach-Anaheim, } \\
\text { CA }\end{array}$ & 12.95 & 3.92 & 1736 & $77.7 \% ; 1.80$ & $\begin{array}{l}\text { Zipcar (traditional and } \\
\text { one-way); } \\
241 \text { cars; } 0.6 / 10 \mathrm{~K}\end{array}$ & Planned, spring 2016 & $\begin{array}{l}\text { Lyft, Uber; } \\
2013\end{array}$ & $\begin{array}{l}\text { LACounty Metropolitan } \\
\text { Transportation Authority } \\
\text { (Metro); } \\
476.3 ; 39.2 \text { p.c. }\end{array}$ \\
\hline $\begin{array}{l}\text { San Francisco- } \\
\text { Oakland- } \\
\text { Hayward, CA }\end{array}$ & 4.40 & 0.85 & 524 & $65.1 \% ; 1.69$ & $\begin{array}{l}\text { City CarShare, } \\
\text { Enterprise, Scoot, } \\
\text { Zipcar (traditional'; } \\
1315 \text { cars; } 15.5 / 10 \mathrm{~K} \\
\text { Getaround (p2p); } \\
1230 \text { cars; } 14.4 / 10 \mathrm{~K}\end{array}$ & $\begin{array}{l}\text { Bay Area Bikeshare; } \\
700 \text { bikes, } 70 \text { stations; } \\
8.2 / 10 \mathrm{~K}\end{array}$ & $\begin{array}{l}\text { Lyft, Uber; } \\
2011 \\
\text { Chariot } \\
\text { (microtransit); } \\
2014\end{array}$ & $\begin{array}{l}\text { San Francisco Municipal } \\
\text { Raihway (Muni); } \\
223.9 ; 68.2 \text { p.c. } \\
\text { Bay Area Rapid Transit District } \\
\text { (BART); } \\
\text { 126.5; } 38.6 \text { p.c. } \\
\text { Total: } 350.4 ; 106.8\end{array}$ \\
\hline $\begin{array}{l}\text { Seattle-Tacoma- } \\
\text { Bellevue, WA }\end{array}$ & 3.50 & 0.67 & 1010 & $73.9 \% ; 1.83$ & $\begin{array}{l}\text { Zipcar (traditional), } \\
\text { Car2Go (one-way); } \\
905 \text { cars; 13.5/10K }\end{array}$ & $\begin{array}{l}\text { Pronto; } \\
500 \text { bikes, } 51 \text { stations; } \\
7.5 / 10 \mathrm{~K}\end{array}$ & $\begin{array}{l}\text { Lyft, Uber; } \\
2013\end{array}$ & $\begin{array}{l}\text { King County Metro Transit; } \\
123.2 ; 40.3 \text { p.c. }\end{array}$ \\
\hline $\begin{array}{l}\text { Washington- } \\
\text { Arlington- } \\
\text { Alexandria, DC- } \\
\text { VA-MD-WV }\end{array}$ & 5.76 & 0.66 & 1322 & $69.3 \% ; 1.76$ & $\begin{array}{l}\text { Car2Go (one-way), } \\
\text { Enterprise, Zipcar } \\
\text { (traditional); } \\
1680 \text { cars; } 25.5 / 10 \mathrm{~K} \\
\text { Getaround ( } \mathrm{p} 2 \mathrm{p} \text { ); } \\
105 \text { cars; } 1.48 / 10 \mathrm{~K} \\
\end{array}$ & $\begin{array}{l}\text { Capital Bikeshare; } \\
1538 \text { bikes, } 204 \text { stations; } \\
\text { 23.3/10K }\end{array}$ & $\begin{array}{l}\text { Lyft, Uber; } \\
2011 \\
\text { Bridj, Split } \\
\text { (microtransit); } \\
2015\end{array}$ & $\begin{array}{l}\text { Washington Metropolitan } \\
\text { Area Transit Authority } \\
\text { (WMATA); } \\
413.6 ; 90.2\end{array}$ \\
\hline
\end{tabular}

-p2p = peer-to-peer.

Sources: U.S. Census Bureau American Community Survey 2014, 5-year estimates (metro and city population, commute mode, household vehicles, occupied housing units); National Transit Database 2013 profiles (transit system data, service area population; trips per capita uses each transit agency's service area population); SUMC Shared Mobility Database (shared mobility oper ators and vehicle counts as of December 2015).

(Source: National Academies of Sciences, Engineering, and Medicine, 2016) 


\section{Appendix B: Changes in Mobility Post-Lockdown}

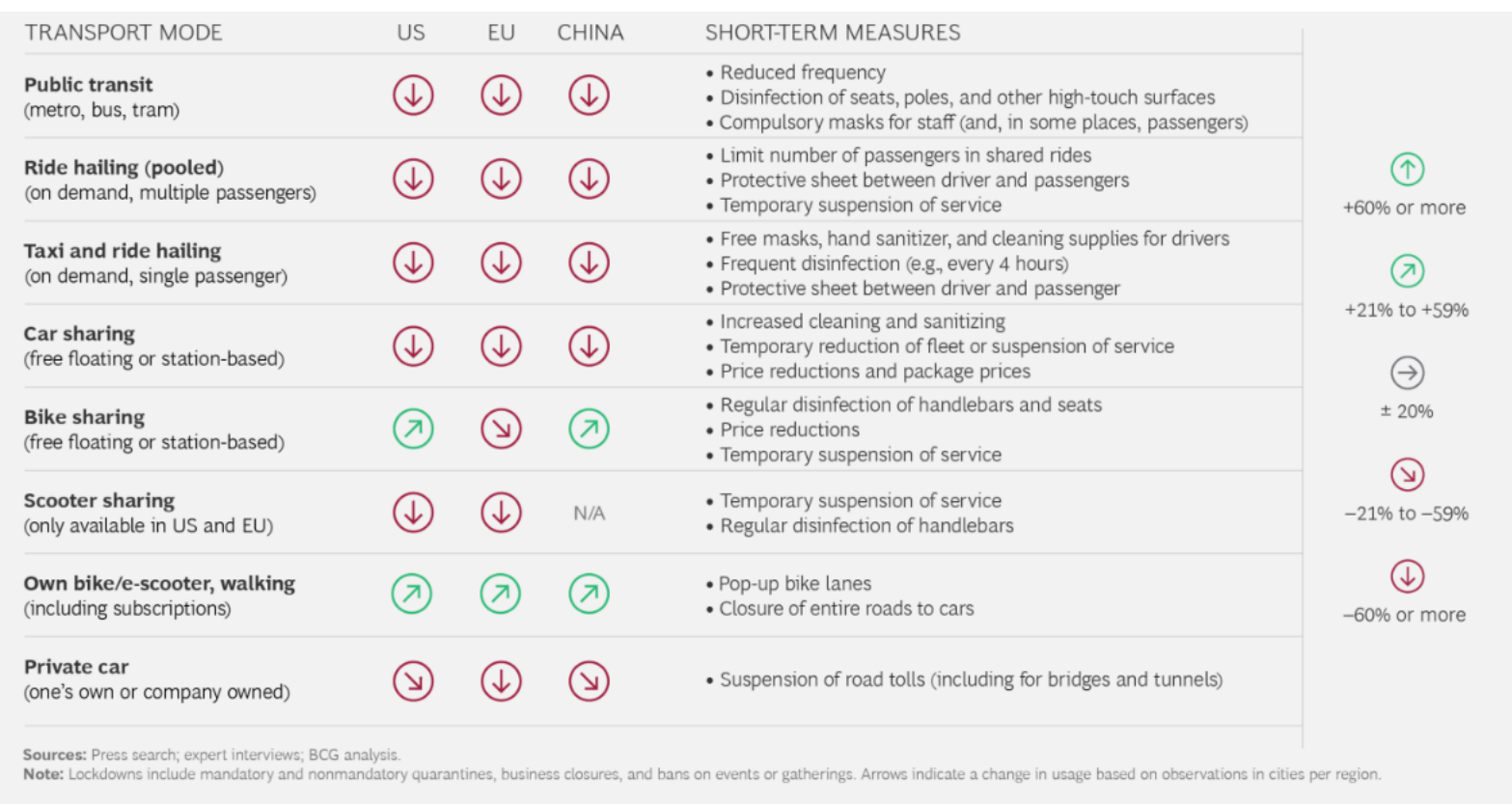

Figure B 1. Shared Mobility Strategies

(Source: Bert et al., 2020)

Exhibit 2 | Change in Urban-Mobility Use Immediately Post-Lockdown

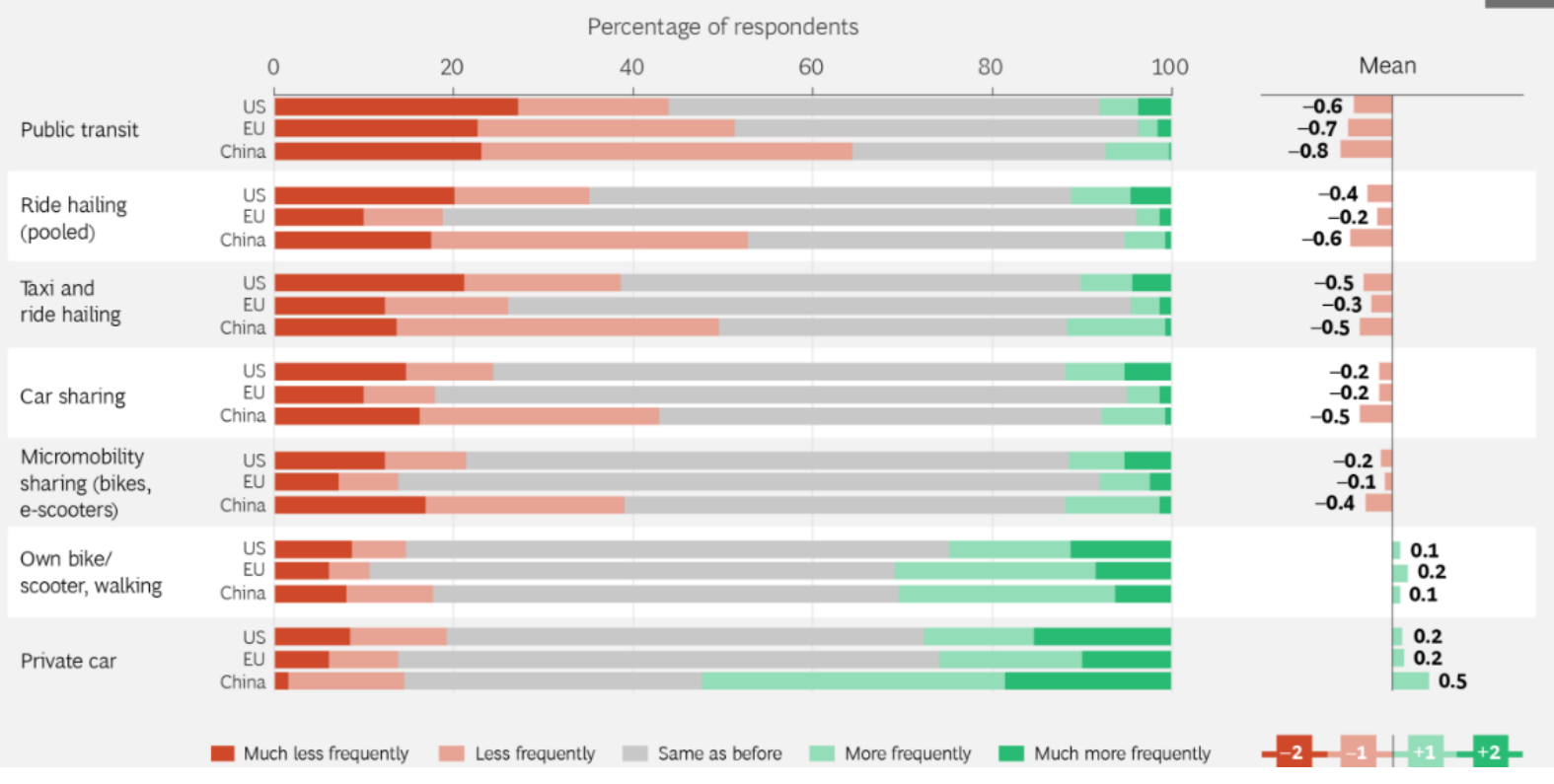

Figure B 2. Change in Travel Behavior Immediately Post-Lockdown

(Source: Bert et al., 2020) 
Exhibit 5 | Change in Urban-Mobility Use Over Time

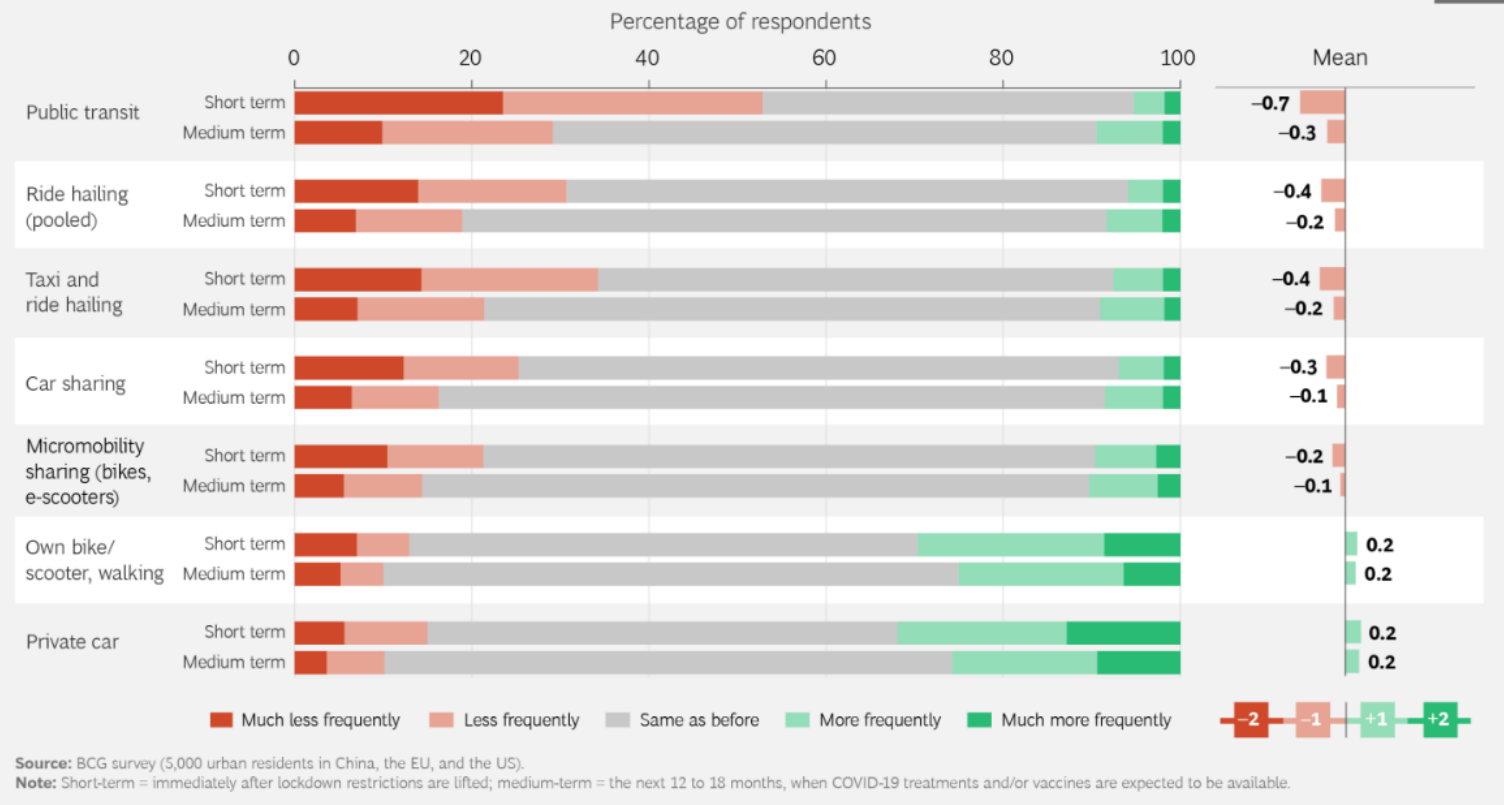

Figure B 3. Change in Travel Behavior Over Time Post-Lockdown (Source: Bert et al., 2020)

Exhibit 4 | User Loyalty Varies by Mode and Depends on Frequency of Use

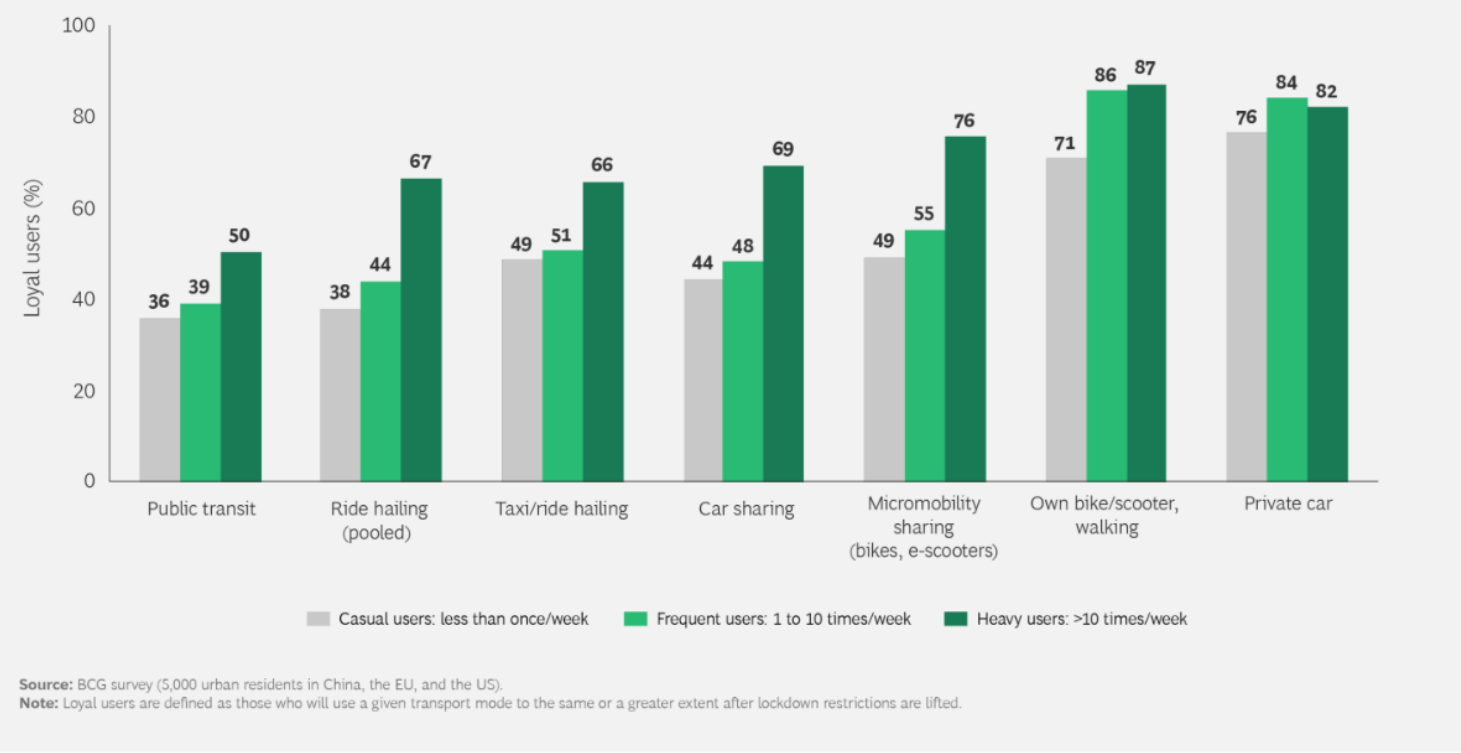

Figure B 4. Change in User Loyalty Post-Lockdown

(Source: Bert et al., 2020) 
Exhibit 3 | Anticipated Spending on Mobility Post-Lockdown

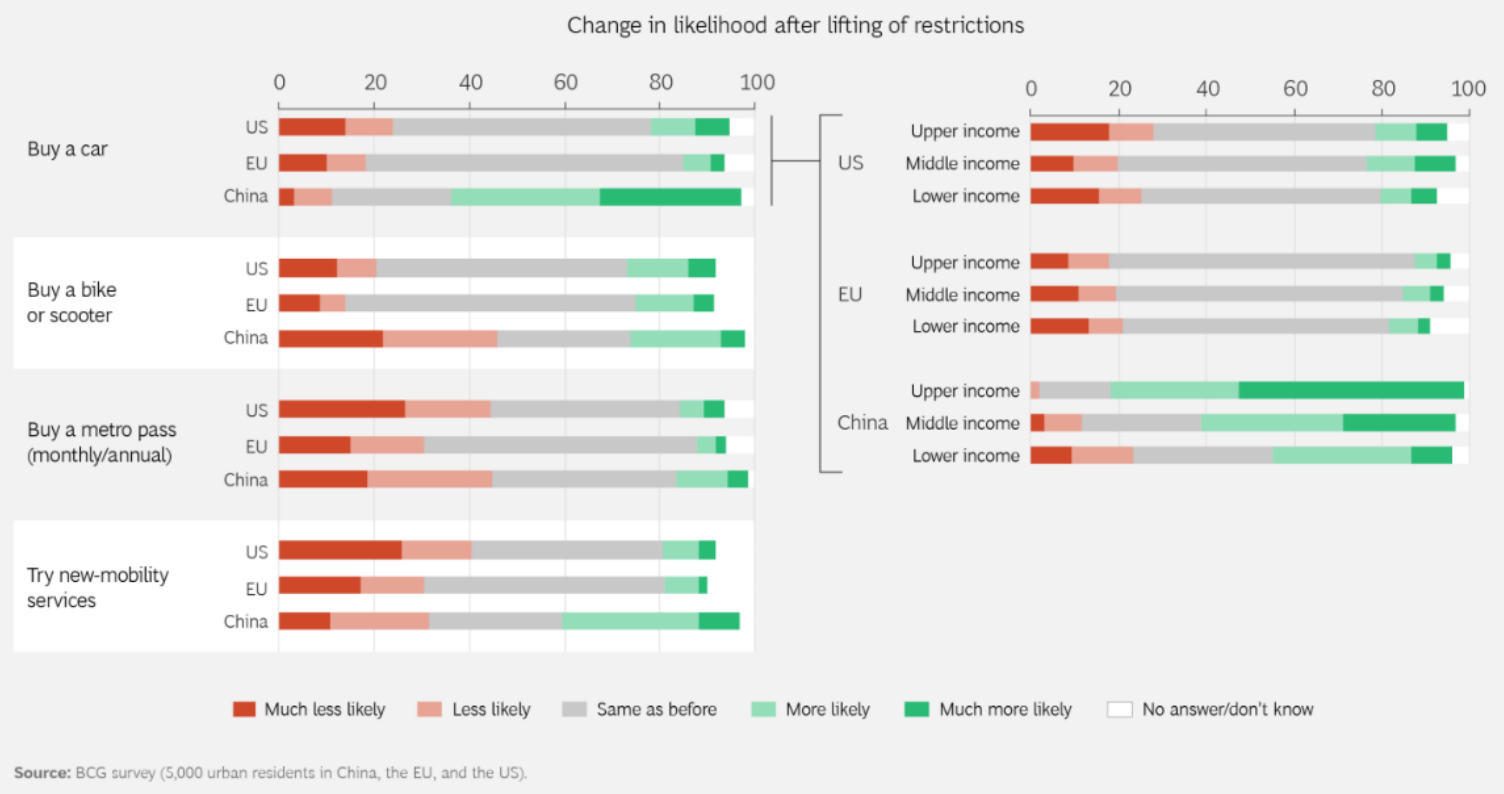

Figure B 5. Anticipated Spending on Various Modes Post-Lockdown

(Source: Bert et al., 2020) 


\section{Appendix C: Survey Instrument}

Impact of COVID-19 on travel behavior, and shared mobility systems

Start of Block: Introduction - Cover Page

Q1.1 University of South Florida USF IRB Protocol: STUDY001076

Dear Respondent,

The COVID-19 global pandemic has impacted our daily life and brought significant changes to how we live, participate in activities, and travel. Stay-At-Home and Social distancing orders imposed at various levels have significantly changed the way we do our activities, work, travel, and use transportation modes for these activities.

The University of South Florida invites you to participate in a research study to better understand how the pandemic has impacted your daily activities, and travel and your views on how some of these changes may continue or not as a consequence of this "new normal". Results of the study will be used to design future transportation options and policy in a post-pandemic world. Your participation is voluntary, but very important.

We are interested in your answer to every question, even those dealing with topics that might be less familiar to you. Your individual responses will be treated in strict confidence. The results of the study will be published only in summary form, so that your identity and privacy are protected. The survey will take about 25 minutes to complete, but we think you will find it interesting and fun to do. Upon completion of the study, you will receive compensation in the amount that you have agreed to with the platform through which you entered this survey.

Thank you in advance for your participation in this important study. This study is sponsored by the US Department of Transportation under its University Transportation Centers Research and Technology program. If you have any questions about the study, please do not hesitate to contact the study coordinator, Nikhil Menon, at nikhilmenon@usf.edu.

Stay healthy and safe,

Nikhil Menon, PhD

Research Associate, Center for Urban Transportation Research

University of South Florida, Tampa

Clicking on the forward button and moving to the next page implies that you are a U.S. resident 18 years or older, you have read the above statement, and you agree to participate in this study. 


\section{SECTION A: GENERAL INFORMATION}

\begin{tabular}{|l|l} 
SECTION A: GENERAL INFORMATION \\
$\qquad \begin{array}{l}\text { In this section, we would like to know more about you and your household. No identifying } \\
\text { information is being collected here so please be as specific as you can. }\end{array}$ \\
\hline
\end{tabular}

1. Which of the following best describes your current gender? (Male, Female, Other, prefer not to answer)

2. In what year were you born? (drop down list: up to 2002)

3. Where were you born? (The US or a US territory, another country, prefer not to answer)

4. Are you Hispanic/Latino(a)? (Yes, No, prefer not to answer)

5. Which of the following categories do you most identify with?
a. Black/African American
e. White/Caucasian
b. Native American/American Indian
f. Mixed Race
c. Asian
g. Other
d. Native Hawaiian/Pacific Islander
h. Prefer not to answer

6. What is the highest level of education you have attained?
a. Some grade/high school
b. Completed high school/GED
d. Bachelor's degree(s) or some graduate school
c. Some college or technical school
e. Completed graduated degree(s)

7. Do you have a driver's license? (Yes, No)

8. When it comes to new technology, what best describes you?
a. I am skeptical of new technologies and use them only when I have to
b. I am usually one of the last people I know to use new technologies
c. I use new technologies when most of the people I know use them
d. I like new technologies and use them before most people I know
e. I love new technologies and am among the first to experiment and use them

9. Which categories best describe your household composition? (Please select all that apply)
a. Living with significant other
d. Living with parents
b. Living with children
e. Living with roommates
c. Living with grandparents
f. Other (please specify)

10. How many people lived in your household (including yourself) under the following categories?

\begin{tabular}{|l|l|}
\hline Children under the age of 5 years & \\
\hline Children between 5 and 12 years & \\
\hline Children between 13 and 17 years & \\
\hline Members in your household who are between $18-64$ years & \\
\hline Workers in your household between $18-64$ years & \\
\hline Members in your household who are 65 years or older & \\
\hline Members in your household who have a underlying health condition(s) & \\
\hline Members in your household with a driver's license & \\
\hline
\end{tabular}

11. Which category best indicated your annual household income before taxes for the year 2019 ?
a. Less than $\$ 25,000$
b. $\$ 25,000-\$ 49,999$
c. $\$ 50,000-\$ 99,999$
d. $\$ 100,000-\$ 149,999$
e. $\$ 150,000-\$ 249,999$
f. $\$ 250,000$ or more 


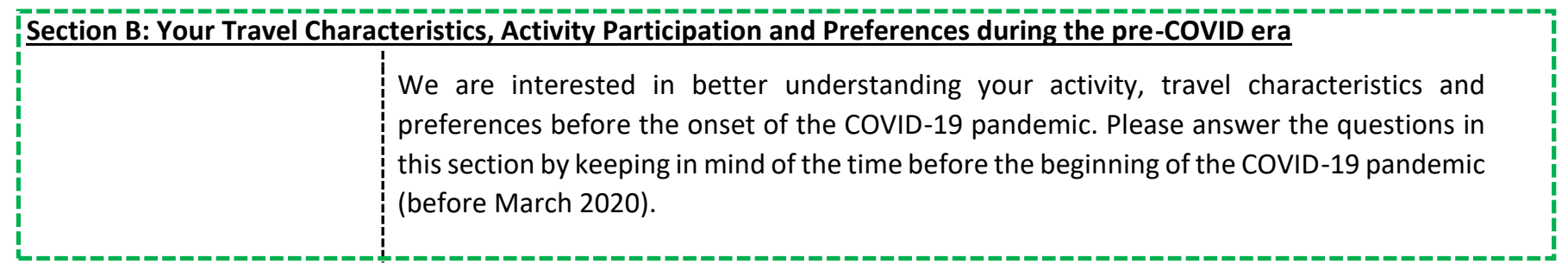

12. How many motorized vehicles (including four-wheelers and two-wheelers) were available in your household before the COVID-19 pandemic?

13. What best describes the home that you lived in before the COVID-19 pandemic?
a. Stand-alone home
d. Mobile home
b. Attached home/townhome
e. Other (please specify):
c. Condo/apartment

14. Did you own or rent your home?
a. Rent
c. Provided by somebody else (e.g.,
b. Own Relative, employer)
d. Other (please specify):

15. Which of the following best described the place where you lived before the COVID-19 pandemic?
a. A large city
c. A small city or town
b. A suburb near a large city
d. A rural area

16. What was the zip code of your home location?

17. Before the COVID-19 pandemic, you were:
a. Primarily a worker but also a part-time student
b. A worker (part-time or full-time)
c. Primarily a student but also a part-time worker
e. Unemployed and looking for work
f. Unemployed and not looking for work (i.e., homemaker, full-time parent)
g. Retired
h. None of the above
d. A student (part-time or full-time)

18. Which among the following job sectors best described your primary job before the COVID-19 pandemic?
a. Administrative Support
f. Marketing/Sales
b. Business/Financial
g. Professional/Technical/IT Services
c. Healthcare/Medical/Pharma
h. Trade/Labor
d. Hospitality/Services
i. Other
e. Logistics/Warehouse/Supply Chain

19. How often were you able to work from home for your primary job before the COVID-19 pandemic?
a. Never had the option
d. 2 or 3 days a week
b. Had the option, but never used it
e. 3 or 4 days a week
c. Once a week
f. All workdays in a week

20. Before the COVID-19 pandemic, how often did you commute to work?
a. Have not commuted at all
d. 3 or 4 days a week
b. Once a week
e. All workdays in a week
c. 2 or 3 days a week

21. Which of the following best described the place where you worked before the COVID-19 pandemic?
a. A large city
c. A small city or town
b. A suburb near a large city
d. A rural area

22. What was the zip code of your primary job location before the COVID-19 pandemic? 
23. Before the COVID-19 pandemic, did you use a single transportation mode or a combination of transportation modes for your typical commute trip?
a. A single transportation mode
b. A combination of transportation modes

24. Please provide information about your typical commute trip before the COVID-19 pandemic.

\begin{tabular}{|c|c|c|c|c|c|c|c|c|c|}
\hline $\begin{array}{l}\text { Primary mode of } \\
\text { travel from home } \\
\text { to work location }\end{array}$ & $\begin{array}{l}\text { Drive } \\
\text { Alone }\end{array}$ & $\begin{array}{c}\text { Share } \\
\text { ride, as a } \\
\text { driver/ } \\
\text { passenger }\end{array}$ & $\begin{array}{l}\text { Taxi } \\
\text { Cab } \\
\text { Ube } \\
\text { /Lyf }\end{array}$ & $\begin{array}{c}\text { Rental } \\
\text { car/ } \\
\text { Carshare } \\
\text { [e.g., } \\
\text { Zipcar] }\end{array}$ & $\begin{array}{c}\text { UberPOOL } \\
\text { /Lyft } \\
\text { Share }\end{array}$ & $\begin{array}{l}\text { Public } \\
\text { Bus } \\
\text { Transit }\end{array}$ & $\begin{array}{c}\text { Rail } \\
\text { Transit }\end{array}$ & $\begin{array}{c}\text { Bicycle/ } \\
\text { Bikeshare }\end{array}$ & $\begin{array}{l}\text { E- } \\
\text { bike/E- } \\
\text { Scooter }\end{array}$ \\
\hline
\end{tabular}

\begin{tabular}{|c|c|c|c|c|c|c|c|c|}
\hline $\begin{array}{c}\text { One-way travel time } \\
\text { from your home to } \\
\text { work location }\end{array}$ & $\begin{array}{c}\text { Less than } \\
5 \text { mins }\end{array}$ & $5-9$ mins & $\begin{array}{c}10-19 \\
\text { mins }\end{array}$ & $\begin{array}{c}20-29 \\
\text { mins }\end{array}$ & $\begin{array}{c}30-44 \\
\text { mins }\end{array}$ & $\begin{array}{c}45-59 \\
\text { mins }\end{array}$ & $\begin{array}{c}60-89 \\
\text { mins }\end{array}$ & $\begin{array}{c}90 \text { mins or } \\
\text { more }\end{array}$ \\
\hline
\end{tabular}

25. Before the COVID-19 pandemic, you were:
a. A student living on-campus
b. A student living off-campus

26. How many courses have you taken under the remote/online learning option before the COVID-19 pandemic?
a. Never had the option
d. 3-4 courses
b. Had the option, but never used it
e. More than 4 courses
c. 1-2 courses

27. Before the COVID-19 pandemic, how often did you commute to school/university?
a. Have not commuted at all
d. 3 to 4 days
b. Once a week
e. All workdays in a week
c. 2 to 3 days a week

28. What was the zip code of your school/university campus?

29. Before the COVID-19 pandemic, did you use a single transportation mode or a combination of transportation modes for your commute trip to school/university?
a. A single transportation mode
b. A combination of transportation modes

30. Please provide information about your trip to school/university before the COVID-19 pandemic.

\begin{tabular}{|c|c|c|c|c|c|c|c|c|c|c|}
\hline $\begin{array}{c}\text { Primary mode of } \\
\text { travel from home } \\
\text { to } \\
\text { school/university }\end{array}$ & $\begin{array}{l}\text { Drive } \\
\text { Alone }\end{array}$ & $\begin{array}{l}\text { Share } \\
\text { ride, as a } \\
\text { driver/ } \\
\text { passenger }\end{array}$ & $\begin{array}{l}\text { Taxi/ } \\
\text { Cab/ } \\
\text { Uber } \\
\text { /Lyft }\end{array}$ & $\begin{array}{c}\text { Rental } \\
\text { car/ } \\
\text { Carshare } \\
\text { [e.g., } \\
\text { Zipcar] }\end{array}$ & $\begin{array}{c}\text { UberPOOL } \\
\text { /Lyft } \\
\text { Share }\end{array}$ & $\begin{array}{l}\text { Public } \\
\text { Bus } \\
\text { Transit }\end{array}$ & $\begin{array}{c}\text { Rail } \\
\text { Transit }\end{array}$ & $\begin{array}{c}\text { Bicycle/ } \\
\text { Bikeshare }\end{array}$ & $\begin{array}{c}\text { E- } \\
\text { bike/E- } \\
\text { Scooter }\end{array}$ & $\begin{array}{l}\text { W } \\
\text { al } \\
k\end{array}$ \\
\hline
\end{tabular}

\begin{tabular}{|c|c|c|c|c|c|c|c|c|}
\hline $\begin{array}{c}\text { One-way travel time } \\
\text { from your home to } \\
\text { school/university }\end{array}$ & $\begin{array}{c}\text { Less than } \\
5 \text { mins }\end{array}$ & $5-9$ mins & $\begin{array}{c}10-19 \\
\text { mins }\end{array}$ & $\begin{array}{c}20-29 \\
\text { mins }\end{array}$ & $\begin{array}{c}30-44 \\
\text { mins }\end{array}$ & $\begin{array}{c}45-59 \\
\text { mins }\end{array}$ & $\begin{array}{c}60-89 \\
\text { mins }\end{array}$ & $\begin{array}{c}90 \text { mins or } \\
\text { more }\end{array}$ \\
\hline
\end{tabular}

31. Please provide information about your trip to the grocery store before the COVID-19 pandemic.

\begin{tabular}{|c|c|c|c|c|c|c|c|c|c|c|}
\hline $\begin{array}{l}\text { Primary mode of } \\
\text { travel from home } \\
\text { to the grocery } \\
\text { store }\end{array}$ & $\begin{array}{l}\text { Drive } \\
\text { Alone }\end{array}$ & $\begin{array}{l}\text { Share } \\
\text { ride, as a } \\
\text { driver/ } \\
\text { passenger }\end{array}$ & $\begin{array}{l}\text { Taxi/ } \\
\text { Cab/ } \\
\text { Uber } \\
\text { /Lyft }\end{array}$ & $\begin{array}{c}\text { Rental } \\
\text { car/ } \\
\text { Carshare } \\
\text { [e.g., } \\
\text { Zipcar] }\end{array}$ & $\begin{array}{c}\text { UberPOOL } \\
\text { /Lyft } \\
\text { Share }\end{array}$ & $\begin{array}{c}\text { Public } \\
\text { Bus } \\
\text { Transit }\end{array}$ & $\begin{array}{c}\text { Rail } \\
\text { Transit }\end{array}$ & $\begin{array}{c}\text { Bicycle/ } \\
\text { Bikeshare }\end{array}$ & $\begin{array}{c}\text { E- } \\
\text { bike/E- } \\
\text { Scooter }\end{array}$ & $\begin{array}{l}\text { W } \\
\text { al } \\
k\end{array}$ \\
\hline
\end{tabular}




\begin{tabular}{|c|c|c|c|c|c|c|c|c|}
\hline $\begin{array}{c}\text { One-way travel time } \\
\text { from your home to } \\
\text { the grocery store }\end{array}$ & $\begin{array}{c}\text { Less than } \\
5 \text { mins }\end{array}$ & $5-9$ mins & $\begin{array}{c}10-19 \\
\text { mins }\end{array}$ & $\begin{array}{c}20-29 \\
\text { mins }\end{array}$ & $\begin{array}{c}30-44 \\
\text { mins }\end{array}$ & $\begin{array}{c}45-59 \\
\text { mins }\end{array}$ & $\begin{array}{c}60-89 \\
\text { mins }\end{array}$ & $\begin{array}{c}90 \text { mins or } \\
\text { more }\end{array}$ \\
\hline
\end{tabular}

32. Please indicate how often you have used the following transportation modes for any trips before the COVID-19 pandemic (in the last year)?

\begin{tabular}{|l|l|l|l|l|l|l|l|}
\hline & $\begin{array}{c}\text { Not } \\
\text { available }\end{array}$ & $\begin{array}{c}\text { Available } \\
\text { but I never } \\
\text { use it }\end{array}$ & $\begin{array}{c}\text { Once or } \\
\text { twice a } \\
\text { year }\end{array}$ & $\begin{array}{c}\text { Once in 2-3 } \\
\text { months }\end{array}$ & $\begin{array}{c}1-3 \\
\text { days a } \\
\text { month }\end{array}$ & $\begin{array}{c}1-2 \\
\text { days a } \\
\text { week }\end{array}$ & $\begin{array}{c}3 \text { or more } \\
\text { days a } \\
\text { week }\end{array}$ \\
\hline Share ride, as a driver/passenger & & & & & & & \\
\hline Taxi/Cab/ Uber/ Lyft & & & & & & & \\
\hline Carshare service (e.g., Zipcar) & & & & & & & \\
\hline Uber POOL/Lyft Share & & & & & & & \\
\hline Public Bus Transit & & & & & & & \\
\hline Rail Transit & & & & & & & \\
\hline Airplane & & & & & & & \\
\hline Bicycle/Bikeshare & & & & & & & \\
\hline E-bike/E-scooter & & & & & & & \\
\hline
\end{tabular}

33. Before the COVID-19 pandemic (in the last year), how often did you participate in the following activities?

\begin{tabular}{|l|c|c|c|c|c|c|}
\hline & $\begin{array}{c}\text { Did not } \\
\text { do this } \\
\text { activity }\end{array}$ & $\begin{array}{c}\text { Once or } \\
\text { twice a } \\
\text { year }\end{array}$ & $\begin{array}{c}\text { Once in 2-3 } \\
\text { months }\end{array}$ & $\begin{array}{c}1-3 \\
\text { days a } \\
\text { month }\end{array}$ & $\begin{array}{c}1-2 \\
\text { days a } \\
\text { week }\end{array}$ & $\begin{array}{c}3 \text { or more } \\
\text { days a } \\
\text { week }\end{array}$ \\
\hline Attend a social gathering (e.g., wedding, funeral) & & & & & & \\
\hline Attend a church or a religious service & & & & & & \\
\hline Wear a face covering/mask while going out & & & & & & \\
\hline Attend a sporting event, concert, or play & & & & & & \\
\hline Take a road trip & & & & & & \\
\hline Travel in an Amtrak train & & & & & & \\
\hline Travel by airplane for work/business & & & & & & \\
\hline Travel by airplane for sightseeing/leisure & & & & & & \\
\hline
\end{tabular}

34. Before the COVID-19 pandemic (in the last year), how often did you participate in the following activities?

\begin{tabular}{|l|c|c|c|c|c|c|c|}
\hline & $\begin{array}{c}\text { Did not } \\
\text { have the } \\
\text { option }\end{array}$ & $\begin{array}{c}\text { Had the } \\
\text { option but } \\
\text { never used it }\end{array}$ & $\begin{array}{c}\text { Once or } \\
\text { twice a } \\
\text { year }\end{array}$ & $\begin{array}{c}\text { Once in } \\
2-3 \\
\text { months }\end{array}$ & $\begin{array}{c}1-3 \\
\text { days a } \\
\text { month }\end{array}$ & $\begin{array}{c}1-2 \\
\text { days a } \\
\text { week }\end{array}$ & $\begin{array}{c}3 \text { or more } \\
\text { days a } \\
\text { week }\end{array}$ \\
\hline Order groceries for pick up & & & & & & & \\
\hline Order groceries for delivery & & & & & & & \\
\hline Order food for pick up at a restaurant & & & & & & & \\
\hline Order food for delivery from a restaurant & & & & & & \\
\hline Order other items online for delivery & & & & & & & \\
\hline Have someone else shop for me & & & & & & \\
\hline $\begin{array}{l}\text { Attend a virtual meeting (meeting via a } \\
\text { web-app/website) }\end{array}$ & & & & & & & \\
\hline $\begin{array}{l}\text { Attend a tele-health appointment } \\
\text { (doctor's visit via a web-app/website) }\end{array}$ & & & & & & & \\
\hline
\end{tabular}




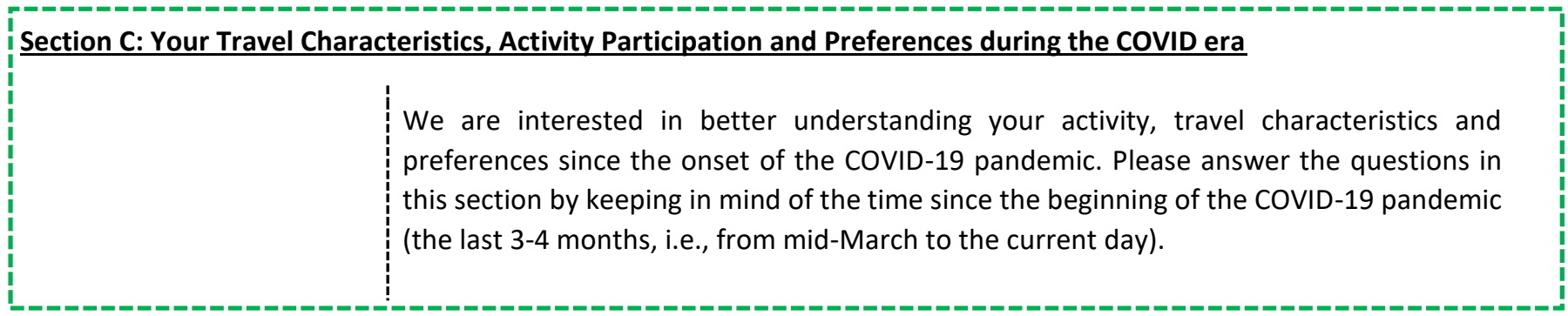

33. Since the onset of the COVID-19 pandemic (please enter a number)

\begin{tabular}{|l|l|}
\hline Number of motorized vehicles bought into your household & \\
\hline Number of motorized vehicles sold into your household & \\
\hline
\end{tabular}

34. Before the COVID-19 pandemic, you were living in a $\$\{q: / / Q I D 10 / C h o i c e G r o u p / S e l e c t e d C h o i c e s\}$. Did you change your household location since the onset of the COVID-19 pandemic? (Yes, No)

35. What best describes the home that you currently live in?
a. Stand-alone home
d. Mobile home
b. Attached home/townhome
e. Other (please specify):
c. Condo/apartment

36. Do you own or rent your current home?
a. Rent
c. Provided by somebody else (e.g.,
b. Own Relative, employer)
d. Other (please specify):

35. Which of the following best described the place where you live since the onset of the COVID-19 pandemic?
a. A large city
c. A small city or town
b. A suburb near a large city
d. A rural area

37. What is the zip code of your current home location?

38. Before the COVID-19 pandemic, you were $\$\{q: / / Q I D 15 / C h o i c e G r o u p / S e l e c t e d C h o i c e s\}$. Have you been working since the onset of the COVID-19 pandemic? (Yes, No)

39. Did you change your primary job since the onset of the COVID-19 pandemic? (Yes, No)

40. Since the onset of the COVID-19 pandemic, you are:
a. Primarily a worker but also a part-time
b. A worker (part-time or full-time) student
c. None of the above

41. Which of the following job sectors best describe your primary job since the onset of the COVID-19 pandemic?
a. Administrative Support
f. Marketing/Sales
b. Business/Financial
g. Professional/Technical/IT Services
c. Healthcare/Medical/Pharma
h. Trade/Labor
d. Hospitality/Services
e. Logistics/Warehouse/Supply Chain
i. Other

36. Which of the following best described the place where you work since the onset of the COVID-19 pandemic?
a. A large city
c. A small city or town
b. A suburb near a large city
d. A rural area

42. What is the zip code of your primary job location since the onset of the COVID-19 pandemic?

43. How often are you able to work from home for your primary job since the onset of the COVID-19 pandemic?
a. Don't have the option
c. Once a week
b. Have the option, but never use it
d. 2 or 3 days a week 

e. 3 or 4 days a week
f. All workdays in a week

44. Since the onset of the COVID-19 pandemic, how often have you commuted to work?
a. Have not commuted at all
d. 3 or 4 days a week
b. Once a week
e. All workdays in a week
c. 2 or 3 days a week

45. Since the onset of the COVID-19 pandemic, did you use a single transportation mode or a combination of transportation modes for your commute trip?
a. A single transportation mode
b. A combination of transportation modes

46. Please provide information about your typical commute trip since the onset of the COVID-19 pandemic.

\begin{tabular}{|c|c|c|c|c|c|c|c|c|c|c|}
\hline $\begin{array}{l}\text { Primary mode of } \\
\text { travel from home } \\
\text { to work location }\end{array}$ & $\begin{array}{l}\text { Drive } \\
\text { Alone }\end{array}$ & $\begin{array}{c}\text { Share } \\
\text { ride, as a } \\
\text { driver/ } \\
\text { passenger }\end{array}$ & $\begin{array}{l}\text { Taxi/ } \\
\text { Cab/ } \\
\text { Uber } \\
\text { /Lyft }\end{array}$ & $\begin{array}{c}\text { Rental } \\
\text { car/ } \\
\text { Carshare } \\
\text { [e.g., } \\
\text { Zipcar] }\end{array}$ & $\begin{array}{c}\text { UberPOOL } \\
\text { /Lyft } \\
\text { Share }\end{array}$ & $\begin{array}{l}\text { Public } \\
\text { Bus } \\
\text { Transit }\end{array}$ & $\begin{array}{c}\text { Rail } \\
\text { Transit }\end{array}$ & $\begin{array}{c}\text { Bicycle/ } \\
\text { Bikeshare }\end{array}$ & $\begin{array}{l}\text { E- } \\
\text { bike/E- } \\
\text { Scooter }\end{array}$ & $\begin{array}{l}\text { W } \\
\text { al } \\
k\end{array}$ \\
\hline
\end{tabular}

\begin{tabular}{|c|c|c|c|c|c|c|c|c|}
\hline $\begin{array}{c}\text { One-way travel time } \\
\text { from your home to } \\
\text { work location }\end{array}$ & $\begin{array}{c}\text { Less than } \\
5 \text { mins }\end{array}$ & $5-9$ mins & $\begin{array}{c}10-19 \\
\text { mins }\end{array}$ & $\begin{array}{c}20-29 \\
\text { mins }\end{array}$ & $\begin{array}{c}30-44 \\
\text { mins }\end{array}$ & $\begin{array}{c}45-59 \\
\text { mins }\end{array}$ & $\begin{array}{c}60-89 \\
\text { mins }\end{array}$ & $\begin{array}{c}90 \text { mins or } \\
\text { more }\end{array}$ \\
\hline
\end{tabular}

47. Have you been a student since the onset of the COVID-19 pandemic? (Yes, No)

48. Did you change your school/university campus since the onset of the COVID-19 pandemic? (Yes, No)

49. Since the onset of the COVID-19 pandemic, you are:
a. Primarily a student but also a part-time worker
b. A student (part-time or full-time)
c. None of the above

50. Since the COVID-19 pandemic, you are:
a. A student living on-campus
b. A student living off-campus

51. What is the zip code of your school/university campus since the onset of the COVID-19 pandemic?

52. Have you commuted to school/university campus for in-person classes since the onset of the COVID-19 pandemic? (Yes, No)

53. Since the onset of the COVID-19 pandemic, did you use a single transportation mode or a combination of transportation modes for your trip to school/university?
a. A single transportation mode
b. A combination of transportation modes 
54. Please provide information about your trip to school/university since the onset of the COVID-19 pandemic.

\begin{tabular}{|c|c|c|c|c|c|c|c|c|c|c|}
\hline $\begin{array}{l}\text { Mode of travel } \\
\text { from home to } \\
\text { school/university }\end{array}$ & $\begin{array}{l}\text { Drive } \\
\text { Alone }\end{array}$ & $\begin{array}{c}\text { Share } \\
\text { ride, as a } \\
\text { driver/ } \\
\text { passenger }\end{array}$ & $\begin{array}{l}\text { Taxi/ } \\
\text { Cab/ } \\
\text { Uber } \\
\text { /Lyft }\end{array}$ & $\begin{array}{c}\text { Rental } \\
\text { car/ } \\
\text { Carshare } \\
\text { [e.g., } \\
\text { Zipcar] }\end{array}$ & $\begin{array}{l}\text { UberPOOL } \\
\text { /Lyft } \\
\text { Share }\end{array}$ & $\begin{array}{l}\text { Public } \\
\text { Bus } \\
\text { Transit }\end{array}$ & $\begin{array}{c}\text { Rail } \\
\text { Transit }\end{array}$ & $\begin{array}{c}\text { Bicycle/ } \\
\text { Bikeshare }\end{array}$ & $\begin{array}{l}\text { E- } \\
\text { bike/E- } \\
\text { Scooter }\end{array}$ & $\begin{array}{l}\text { W } \\
\text { al } \\
k\end{array}$ \\
\hline
\end{tabular}

\begin{tabular}{|c|c|c|c|c|c|c|c|c|}
\hline $\begin{array}{c}\text { One-way travel time } \\
\text { from your home to } \\
\text { school/university }\end{array}$ & $\begin{array}{c}\text { Less than } \\
5 \text { mins }\end{array}$ & $5-9$ mins & $\begin{array}{c}10-19 \\
\text { mins }\end{array}$ & $\begin{array}{c}20-29 \\
\text { mins }\end{array}$ & $\begin{array}{c}30-44 \\
\text { mins }\end{array}$ & $\begin{array}{c}45-59 \\
\text { mins }\end{array}$ & $\begin{array}{c}60-89 \\
\text { mins }\end{array}$ & $\begin{array}{c}90 \text { mins or } \\
\text { more }\end{array}$ \\
\hline
\end{tabular}

55. Have you shopped in-person at the grocery store since the onset of the COVID-19 pandemic? (Yes, No)

56. Please provide information about your trip to the grocery store since the onset of the COVID-19 pandemic.

\begin{tabular}{|c|c|c|c|c|c|c|c|c|c|c|}
\hline $\begin{array}{l}\text { Primary mode of } \\
\text { travel from home } \\
\text { to the grocery } \\
\text { store }\end{array}$ & $\begin{array}{l}\text { Drive } \\
\text { Alone }\end{array}$ & $\begin{array}{l}\text { Share } \\
\text { ride, as a } \\
\text { driver/ } \\
\text { passenger }\end{array}$ & $\begin{array}{l}\text { Taxi/ } \\
\text { Cab/ } \\
\text { Uber } \\
\text { /Lyft }\end{array}$ & $\begin{array}{c}\text { Rental } \\
\text { car/ } \\
\text { Carshare } \\
\text { [e.g., } \\
\text { Zipcar] }\end{array}$ & $\begin{array}{c}\text { UberPOOL } \\
\text { /Lyft } \\
\text { Share }\end{array}$ & $\begin{array}{l}\text { Public } \\
\text { Bus } \\
\text { Transit }\end{array}$ & $\begin{array}{c}\text { Rail } \\
\text { Transit }\end{array}$ & $\begin{array}{c}\text { Bicycle/ } \\
\text { Bikeshare }\end{array}$ & $\begin{array}{c}\text { E- } \\
\text { bike/E- } \\
\text { Scooter }\end{array}$ & $\begin{array}{l}\text { W } \\
\text { al } \\
\text { k }\end{array}$ \\
\hline
\end{tabular}

\begin{tabular}{|c|c|c|c|c|c|c|c|c|}
\hline $\begin{array}{c}\text { One-way travel time } \\
\text { from your home to } \\
\text { the grocery store }\end{array}$ & $\begin{array}{c}\text { Less than } \\
5 \text { mins }\end{array}$ & $5-9$ mins & $\begin{array}{c}10-19 \\
\text { mins }\end{array}$ & $\begin{array}{c}20-29 \\
\text { mins }\end{array}$ & $\begin{array}{c}30-44 \\
\text { mins }\end{array}$ & $\begin{array}{c}45-59 \\
\text { mins }\end{array}$ & $\begin{array}{c}60-89 \\
\text { mins }\end{array}$ & $\begin{array}{c}90 \text { mins or } \\
\text { more }\end{array}$ \\
\hline
\end{tabular}

57. In comparison to that before the pandemic, how often have you used the following modes for your any trips since the onset of the COVID-19 pandemic?

\begin{tabular}{|l|l|l|l|l|l|l|}
\hline & $\begin{array}{c}\text { Did not use } \\
\text { this mode }\end{array}$ & $\begin{array}{c}\text { Much less } \\
\text { than before } \\
\text { the } \\
\text { pandemic }\end{array}$ & $\begin{array}{c}\text { Less than } \\
\text { before the } \\
\text { pandemic }\end{array}$ & $\begin{array}{c}\text { Same as } \\
\text { before the } \\
\text { pandemic }\end{array}$ & $\begin{array}{c}\text { More than } \\
\text { before the } \\
\text { pandemic }\end{array}$ & $\begin{array}{c}\text { Much more } \\
\text { than before } \\
\text { the pandemic }\end{array}$ \\
\hline Share ride, as a driver/passenger & & & & & & \\
\hline Taxi/Cab/ Uber/ Lyft & & & & & & \\
\hline Carshare service (e.g., Zipcar) & & & & & & \\
\hline Uber POOL/Lyft Share & & & & & & \\
\hline Public Bus Transit & & & & & & \\
\hline Rail Transit & & & & & & \\
\hline Airplane & & & & & & \\
\hline Bicycle/Bikeshare & & & & & & \\
\hline E-Bike/E-Scooter & & & & & & \\
\hline
\end{tabular}

58. In comparison to that before the pandemic, how often did you participate in the following activities since the onset of the COVID-19 pandemic?

\begin{tabular}{|l|l|l|l|l|l|l|}
\hline & $\begin{array}{c}\text { Did not } \\
\text { do this } \\
\text { activity }\end{array}$ & $\begin{array}{c}\text { Much less } \\
\text { than before } \\
\text { the pandemic }\end{array}$ & $\begin{array}{c}\text { Less than } \\
\text { before the } \\
\text { pandemic }\end{array}$ & $\begin{array}{c}\text { Same as } \\
\text { before the } \\
\text { pandemic }\end{array}$ & $\begin{array}{c}\text { More than } \\
\text { before the } \\
\text { pandemic }\end{array}$ & $\begin{array}{c}\text { Much more } \\
\text { than } \\
\text { before the } \\
\text { pandemic }\end{array}$ \\
\hline Hug or shake hands when greeting a friend & & & & & & \\
\hline Hug or shake hands when greeting a colleague & & & & & & \\
\hline Attend a social gathering (e.g., wedding, funeral) & & & & & & \\
\hline
\end{tabular}




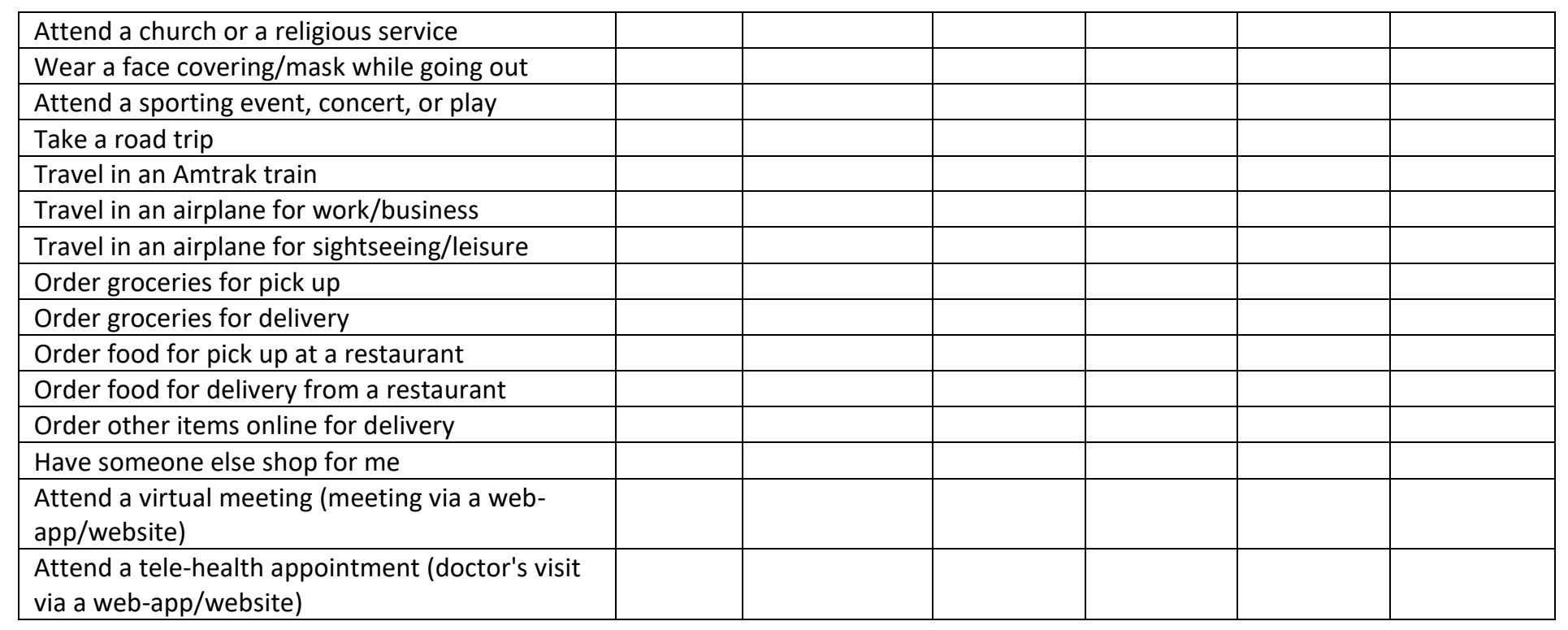

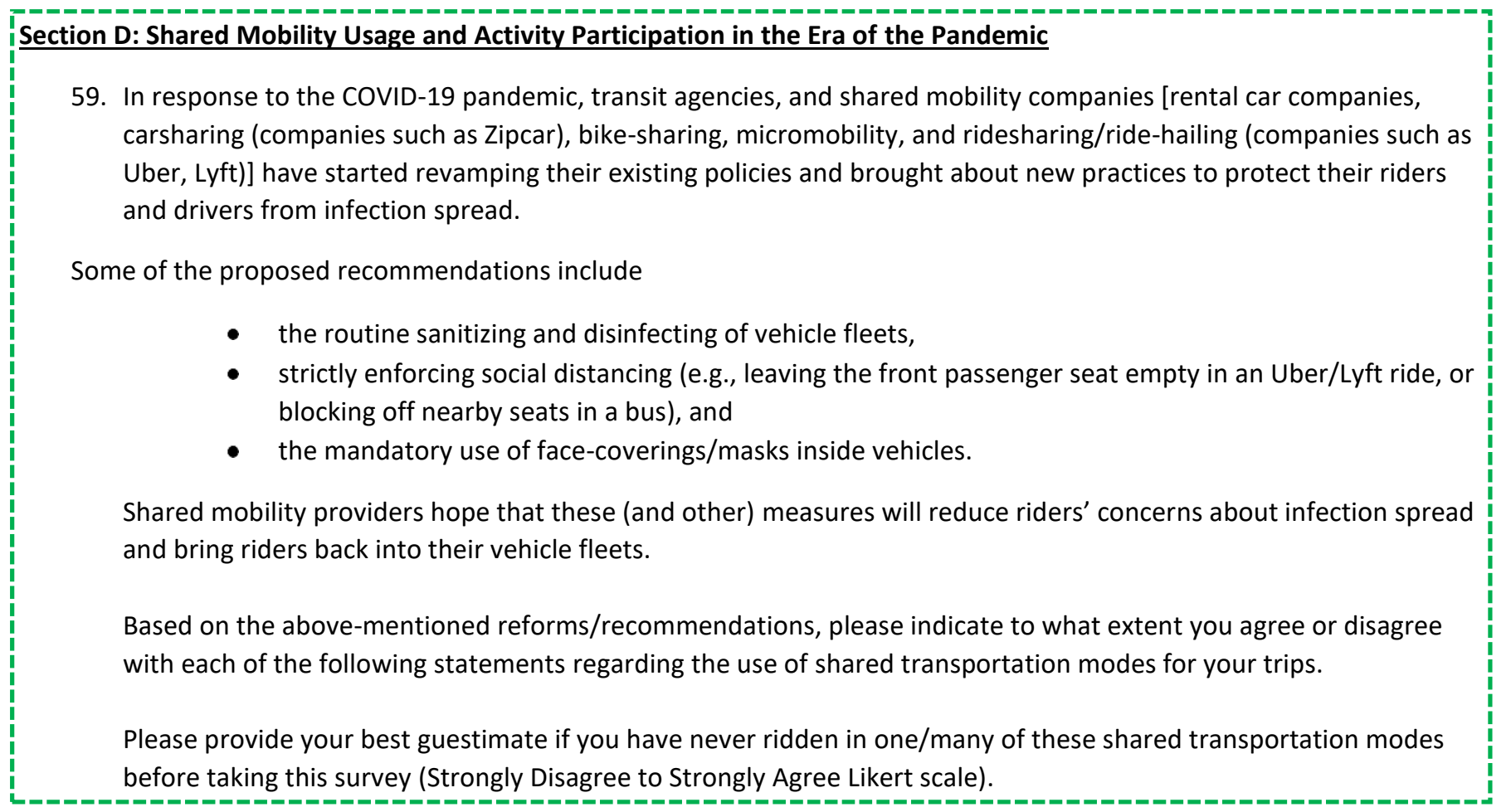

i. I feel confident that I will not get COVID-19 while using:
a. Rental car/Carshare
b. Transit
c. Uber/Lyft,
d. UberPOOL/Lyft Share
e. Bikesharing/E-bike/E-scooter

ii. My underlying health condition(s) make me more prone (than the average person) to get COVID-19 while using:
a. Rental car/Carshare
b. Transit 
c. Uber/Lyft

d. UberPOOL/Lyft Share

e. Bikesharing/E-bike/E-scooter

iii. I have higher levels of trust on the implementation of the infection prevention measures (as suggested above) by:
a. Rental car/Carsharing companies
b. Transit agencies
c. Uber/Lyft driver
d. UberPOOL/Lyft Share driver
e. Bikesharing/E-bike/E-scooter companies

iv. In addition to the above-mentioned measures, any physical separation (such as glass partitions or plastic sheets) between passengers and driver will increase my chances of using:
a. Transit
b. Uber/Lyft
c. UberPOOL/Lyft Share

v. After taking this survey, I will probably never use:
a. Rental car/Carshare
b. Transit
c. Uber/Lyft
d. UberPOOL/Lyft Share
e. Bikesharing/E-bike/E-scooter

vi. Do you have any concerns/suggestions on using:
a. Rental car/Carshare
b. Transit
c. Uber/Lyft
d. UberPOOL/Lyft Share
e. Bikesharing/E-bike/E-scooter

60. In your opinion, by when do you think you could resume the following activities in a manner you did before the COVID-19 pandemic?

\begin{tabular}{|l|l|l|l|l|l|l|}
\hline & $\begin{array}{c}\text { This } \\
\text { summer }\end{array}$ & 3 to 5 months & $\begin{array}{c}6 \text { to } 12 \\
\text { months }\end{array}$ & $\begin{array}{c}\text { More than } \\
\text { a year }\end{array}$ & $\begin{array}{c}\text { Never } \\
\text { again }\end{array}$ & Not sure \\
\hline Hug or shake hands when greeting a friend & & & & & & \\
\hline Hug or shake hands when greeting a colleague & & & & & & \\
\hline Attend a social gathering (e.g., wedding, funeral) & & & & & & \\
\hline Attend a church or a religious service & & & & & & \\
\hline Wear a face covering/mask while going out & & & & & & \\
\hline Attend a sporting event, concert, or play & & & & & & \\
\hline Take a road trip & & & & & & \\
\hline Travel in an Amtrak train & & & & & & \\
\hline Travel in an airplane for work/business & & & & & & \\
\hline Travel in an airplane for sightseeing/leisure & & & & & & \\
\hline Order groceries for pick up & & & & & & \\
\hline Order groceries for delivery & & & & & & \\
\hline Order food for pick up at a restaurant & & & & & & \\
\hline Order food for delivery from a restaurant & & & & & & \\
\hline Order other items online for delivery & & & & & \\
\hline Have someone else shop for me & & & & & \\
\hline $\begin{array}{l}\text { Attend a virtual meeting (meeting via a web- } \\
\text { app/website) }\end{array}$ & & & & & & \\
\hline
\end{tabular}


Attend a tele-health appointment (doctor's visit

via a web-app/website)

61. Please indicate your best estimate of when you could do the following activities in the near future.

\begin{tabular}{|c|c|c|c|c|c|c|}
\hline & $\begin{array}{c}\text { This } \\
\text { summer }\end{array}$ & $\begin{array}{c}3 \text { to } 5 \\
\text { months }\end{array}$ & $\begin{array}{l}6 \text { to } 12 \\
\text { months }\end{array}$ & $\begin{array}{c}\text { More than } \\
\text { a year }\end{array}$ & $\begin{array}{l}\text { Never } \\
\text { again }\end{array}$ & $\begin{array}{l}\text { Not } \\
\text { sure }\end{array}$ \\
\hline \multicolumn{7}{|l|}{ Buying another motorized vehicle into your household } \\
\hline \multicolumn{7}{|c|}{ Selling one of the motorized vehicles from your household } \\
\hline \multicolumn{7}{|l|}{ Changing your household location } \\
\hline \multicolumn{7}{|l|}{ Changing your work/student status } \\
\hline \multicolumn{7}{|l|}{ Commuting regularly for work/school/university } \\
\hline \multicolumn{7}{|l|}{ Dining in regularly at your favorite restaurant(s) } \\
\hline Shopping regularly at your favorite grocery store(s) & & & & & & \\
\hline
\end{tabular}

Section E: Your Travel Characteristics, Activity Participation and Preferences during the post-COVID era
We are interested in better understanding your activity, travel characteristics and
preferences in the post-COVID era. While our understanding of a post-COVID world is
unclear, please answer the questions in this section by assuming a future when the COVID-
19 pandemic is no longer a threat to anyone.

62. Do you plan on changing your home location once the COVID-19 pandemic is no longer a threat? (Yes, Maybe, No)

63. Which of the following best described the place where you would like to live once the COVID-19 pandemic is no longer a threat?
a. A large city
c. A small city or town
b. A suburb near a large city
d. A rural area

64. Do you plan to work once the COVID-19 pandemic is no longer a threat? (Yes, Maybe, No)

65. Do you plan on changing your primary job when the COVID-19 pandemic is no longer a threat? (Yes, No)

66. When the COVID-19 pandemic is no longer a threat, you would ideally be:
a. Primarily a worker but also a part-time
b. A worker (part-time or full-time) student
c. None of the above

67. When the COVID-19 pandemic is no longer a threat, how often do you think you would be able to work from home?
a. I will not have the option
d. 2 or 3 days a week
b. Have the option, but will not use it
e. 3 or 4 days a week
c. Once a week
f. All workdays in a week

68. When the COVID-19 pandemic is no longer a threat, how often would you like to commute to work?
a. I would like to not commute at all
d. 3 or 4 days a week
b. Once a week
e. All workdays in a week
c. 2 or 3 days a week

69. When the COVID-19 pandemic is no longer a threat, would you use a single transportation mode or a combination of transportation modes for your commute trip?
a. A single transportation mode
b. A combination of transportation modes

70. Please provide information about your anticipated commute trip when the COVID-19 pandemic is no longer a threat. 


\begin{tabular}{|c|c|c|c|c|c|c|c|c|c|c|}
\hline $\begin{array}{l}\text { Primary mode of } \\
\text { travel from home } \\
\text { to work location }\end{array}$ & $\begin{array}{l}\text { Drive } \\
\text { Alone }\end{array}$ & $\begin{array}{c}\text { Share } \\
\text { ride, as a } \\
\text { driver/ } \\
\text { passenger }\end{array}$ & $\begin{array}{l}\text { Taxi/ } \\
\text { Cab/ } \\
\text { Uber } \\
\text { /Lyft }\end{array}$ & $\begin{array}{c}\text { Rental } \\
\text { car/ } \\
\text { Carshare } \\
\text { [e.g., } \\
\text { Zipcar] }\end{array}$ & $\begin{array}{c}\text { UberPOOL } \\
\text { /Lyft } \\
\text { Share }\end{array}$ & $\begin{array}{l}\text { Public } \\
\text { Bus } \\
\text { Transit }\end{array}$ & $\begin{array}{c}\text { Rail } \\
\text { Transit }\end{array}$ & $\begin{array}{c}\text { Bicycle/ } \\
\text { Bikeshare }\end{array}$ & $\begin{array}{c}\text { E- } \\
\text { bike/E- } \\
\text { Scooter }\end{array}$ & $\begin{array}{l}\text { W } \\
\text { al } \\
k\end{array}$ \\
\hline
\end{tabular}

\begin{tabular}{|c|c|c|c|c|c|}
\hline $\begin{array}{c}\text { One-way travel time } \\
\text { from your home to } \\
\text { work location }\end{array}$ & $\begin{array}{c}\text { Much less } \\
\text { than before } \\
\text { the pandemic }\end{array}$ & $\begin{array}{c}\text { Less than } \\
\text { before the } \\
\text { pandemic }\end{array}$ & $\begin{array}{c}\text { Same as } \\
\text { before the } \\
\text { pandemic }\end{array}$ & $\begin{array}{c}\text { More than } \\
\text { before the } \\
\text { pandemic }\end{array}$ & $\begin{array}{c}\text { Much more } \\
\text { than before } \\
\text { the pandemic }\end{array}$ \\
\hline
\end{tabular}

71. Do you plan to be a student once the COVID-19 pandemic is no longer a threat? (Yes, Maybe, No)

72. Do you plan on changing your school/university campus when the COVID-19 pandemic is no longer a threat? (Yes, No)

73. When the COVID-19 pandemic is no longer a threat, you would ideally be:
a. Primarily a student but also a part-time
b. A student (part-time or full-time) worker
c. None of the above

74. When the COVID-19 pandemic is no longer a threat, you would ideally be:
a. A student living on-campus
b. A student living off-campus

75. How many online/in-person courses are you planning to take when the COVID-19 pandemic is no longer a threat?
a. Will not take any online course
d. Same number of online and in-person
b. Will not take any in-person course courses
c. More online than in-person courses
e. More in-person than online courses

76. When the COVID-19 pandemic is no longer a threat, how often would you like to commute to school/university campus for classes and/or other activities?
a. I would not like to commute at all
d. 3 or 4 days a week
b. Once a week
e. All workdays in a week
c. 2 or 3 days a week

77. When the COVID-19 pandemic is no longer a threat, would you use a single transportation mode or a combination of transportation modes for your trip to school/university campus?
a. A single transportation mode
b. A combination of transportation modes

78. Please provide information about your trip to school/university when the COVID-19 pandemic is no longer a threat.

\begin{tabular}{|c|c|c|c|c|c|c|c|c|c|c|}
\hline $\begin{array}{l}\text { Mode of travel } \\
\text { from home to } \\
\text { school/university }\end{array}$ & $\begin{array}{l}\text { Drive } \\
\text { Alone }\end{array}$ & $\begin{array}{l}\text { Share } \\
\text { ride, as a } \\
\text { driver/ } \\
\text { passenger }\end{array}$ & $\begin{array}{l}\text { Taxi } \\
\text { Cab, } \\
\text { Ube } \\
\text { /Lyf }\end{array}$ & $\begin{array}{c}\text { Rental } \\
\text { car/ } \\
\text { Carshare } \\
\text { [e.g., } \\
\text { Zipcar] }\end{array}$ & $\begin{array}{c}\text { UberPOOL } \\
\text { /Lyft } \\
\text { Share }\end{array}$ & $\begin{array}{l}\text { Public } \\
\text { Bus } \\
\text { Transit }\end{array}$ & $\begin{array}{c}\text { Rail } \\
\text { Transit }\end{array}$ & $\begin{array}{c}\text { Bicycle/ } \\
\text { Bikeshare }\end{array}$ & $\begin{array}{c}\text { E- } \\
\text { bike/E- } \\
\text { Scooter }\end{array}$ & $\begin{array}{l}\text { W } \\
\text { al } \\
k\end{array}$ \\
\hline
\end{tabular}

\begin{tabular}{|c|c|c|c|c|c|}
\hline $\begin{array}{c}\text { One-way travel time } \\
\text { from your home to } \\
\text { school/university }\end{array}$ & $\begin{array}{c}\text { Much less } \\
\text { than before } \\
\text { the pandemic }\end{array}$ & $\begin{array}{c}\text { Less than } \\
\text { before the } \\
\text { pandemic }\end{array}$ & $\begin{array}{c}\text { Same as } \\
\text { before the } \\
\text { pandemic }\end{array}$ & $\begin{array}{c}\text { More than } \\
\text { before the } \\
\text { pandemic }\end{array}$ & $\begin{array}{c}\text { Much more } \\
\text { than before } \\
\text { the pandemic }\end{array}$ \\
\hline
\end{tabular}

79. Do you plan to shop in-person at the grocery store once the COVID-19 pandemic is no longer a threat? (Yes, Maybe, No)

80. Please provide information about your anticipated trip to the grocery store when the COVID-19 pandemic is no longer a threat. 


\begin{tabular}{|c|c|c|c|c|c|c|c|c|c|c|}
\hline $\begin{array}{l}\text { Primary mode of } \\
\text { travel from home } \\
\text { to the grocery } \\
\text { store }\end{array}$ & $\begin{array}{l}\text { Drive } \\
\text { Alone }\end{array}$ & $\begin{array}{l}\text { Share } \\
\text { ride, as a } \\
\text { driver/ } \\
\text { passenger }\end{array}$ & $\begin{array}{l}\text { Taxi/ } \\
\text { Cab/ } \\
\text { Uber } \\
\text { /Lyft }\end{array}$ & $\begin{array}{c}\text { Rental } \\
\text { car/ } \\
\text { Carshare } \\
\text { [e.g., } \\
\text { Zipcar] }\end{array}$ & $\begin{array}{c}\text { UberPOOL } \\
\text { /Lyft } \\
\text { Share }\end{array}$ & $\begin{array}{l}\text { Public } \\
\text { Bus } \\
\text { Transit }\end{array}$ & $\begin{array}{c}\text { Rail } \\
\text { Transit }\end{array}$ & $\begin{array}{c}\text { Bicycle/ } \\
\text { Bikeshare }\end{array}$ & $\begin{array}{l}\text { E- } \\
\text { bike/E- } \\
\text { Scooter }\end{array}$ & $\begin{array}{l}\text { W } \\
\text { al } \\
k\end{array}$ \\
\hline
\end{tabular}

\begin{tabular}{|c|c|c|c|c|c|}
\hline $\begin{array}{c}\text { One-way travel time } \\
\text { from your home to } \\
\text { the grocery store }\end{array}$ & $\begin{array}{c}\text { Much less } \\
\text { than before } \\
\text { the pandemic }\end{array}$ & $\begin{array}{c}\text { Less than } \\
\text { before the } \\
\text { pandemic }\end{array}$ & $\begin{array}{c}\text { Same as } \\
\text { before the } \\
\text { pandemic }\end{array}$ & $\begin{array}{c}\text { More than } \\
\text { before the } \\
\text { pandemic }\end{array}$ & $\begin{array}{c}\text { Much more } \\
\text { than before the } \\
\text { pandemic }\end{array}$ \\
\hline
\end{tabular}

81. In comparison to that before the pandemic, how often would you use the following modes for any trips when the COVID-19 pandemic is no longer a threat?

\begin{tabular}{|l|l|c|c|c|c|c|}
\hline & $\begin{array}{c}\text { Will not use } \\
\text { this mode }\end{array}$ & $\begin{array}{c}\text { Much less } \\
\text { than before } \\
\text { the pandemic }\end{array}$ & $\begin{array}{c}\text { Less than } \\
\text { before the } \\
\text { pandemic }\end{array}$ & $\begin{array}{c}\text { Same as } \\
\text { before the } \\
\text { pandemic }\end{array}$ & $\begin{array}{c}\text { More than } \\
\text { before the } \\
\text { pandemic }\end{array}$ & $\begin{array}{c}\text { Much more } \\
\text { than before the } \\
\text { pandemic }\end{array}$ \\
\hline Share ride, as a driver/passenger & & & & & & \\
\hline Taxi/Cab/ Uber/ Lyft & & & & & & \\
\hline Carshare service (e.g., Zipcar) & & & & & & \\
\hline Uber POOL/Lyft Share & & & & & & \\
\hline Public Bus Transit & & & & & & \\
\hline Rail Transit & & & & & & \\
\hline Airplane & & & & & & \\
\hline Bicycle/Bikeshare & & & & & & \\
\hline
\end{tabular}

82. In comparison to that before the pandemic, how often did you participate in the following activities once the COVID19 pandemic is no longer a threat?

\begin{tabular}{|l|l|l|l|l|l|l|}
\hline & $\begin{array}{c}\text { Will not } \\
\text { do this } \\
\text { activity }\end{array}$ & $\begin{array}{c}\text { Much less } \\
\text { than before } \\
\text { the pandemic }\end{array}$ & $\begin{array}{c}\text { Less than } \\
\text { before the } \\
\text { pandemic }\end{array}$ & $\begin{array}{c}\text { Same as } \\
\text { before the } \\
\text { pandemic }\end{array}$ & $\begin{array}{c}\text { More than } \\
\text { before the } \\
\text { pandemic }\end{array}$ & $\begin{array}{c}\text { Much more } \\
\text { than before } \\
\text { the } \\
\text { pandemic }\end{array}$ \\
\hline Attend a social gathering (e.g., wedding, funeral) & & & & & & \\
\hline Hug or shake hands when greeting a friend & & & & & & \\
\hline Hug or shake hands when greeting a colleague & & & & & & \\
\hline Attend a church or a religious service & & & & & & \\
\hline Wear a face covering/mask & & & & & & \\
\hline Attend a sporting event, concert, or play & & & & & & \\
\hline Take a road trip & & & & & & \\
\hline Travel in an Amtrak train & & & & & & \\
\hline Travel in an airplane for work/business & & & & & & \\
\hline Travel in an airplane for sightseeing/leisure & & & & & & \\
\hline Order groceries for pick up & & & & & & \\
\hline Order groceries for delivery & & & & & & \\
\hline Order food for pick up at a restaurant & & & & & & \\
\hline Order food for delivery from a restaurant & & & & & & \\
\hline Order other items online for delivery & & & & & & \\
\hline Have someone else shop for me & & & & & \\
\hline $\begin{array}{l}\text { Attend a virtual meeting (meeting via a web- } \\
\text { app/website) }\end{array}$ & & & & & & \\
\hline $\begin{array}{l}\text { Attend a tele-health appointment (doctor's visit } \\
\text { via a web-app/website) }\end{array}$ & & & & & & \\
\hline
\end{tabular}




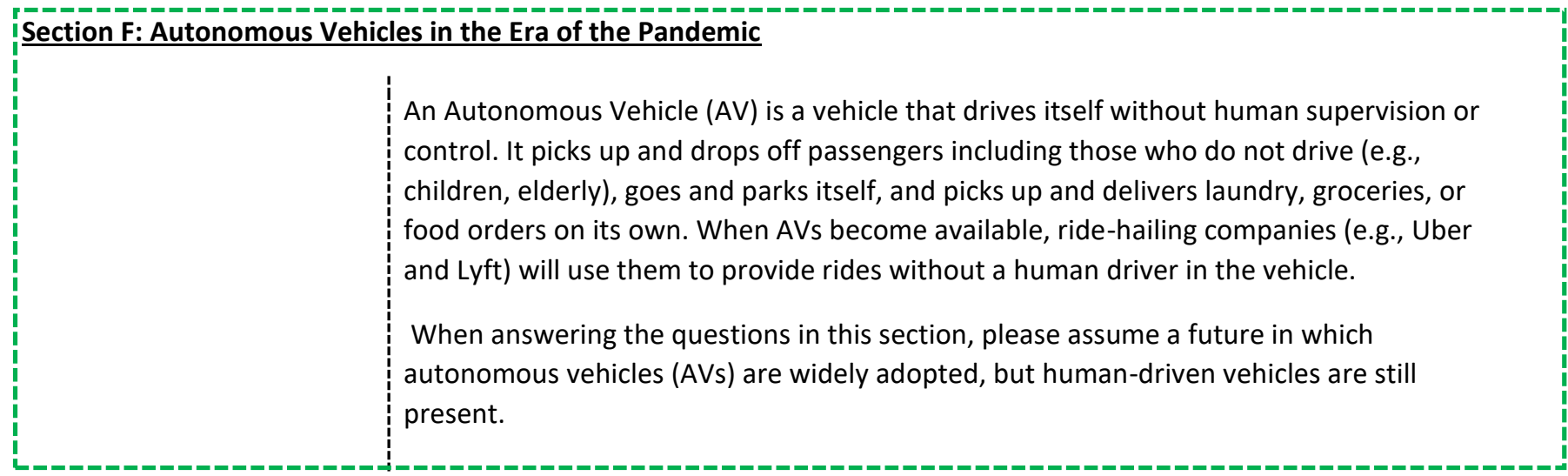

83. How familiar were you with autonomous vehicles (AVs) before taking this survey?
a. I had never heard of AVs before taking
c. I am somewhat familiar with AVs this survey
d. I am very familiar with AVs
b. I have heard of AVs, but do not know
e. I have actually taken a ride in an AV much about them

84. Have you ridden in an autonomous vehicle before taking this survey?
a. Yes
b. Maybe/Not Sure
c. No

85. How likely do you see yourself using an AV for your travel needs when they become available in the market?

\begin{tabular}{|l|l|l|l|l|l|l|}
\hline & $\begin{array}{c}\text { Will not use } \\
\text { this mode }\end{array}$ & $\begin{array}{c}\text { Much less } \\
\text { than before } \\
\text { the pandemic }\end{array}$ & $\begin{array}{c}\text { Less than } \\
\text { before the } \\
\text { pandemic }\end{array}$ & $\begin{array}{c}\text { Same as } \\
\text { before the } \\
\text { pandemic }\end{array}$ & $\begin{array}{c}\text { More than } \\
\text { before the } \\
\text { pandemic }\end{array}$ & $\begin{array}{c}\text { Much more } \\
\text { than before the } \\
\text { pandemic }\end{array}$ \\
\hline $\begin{array}{l}\text { All commute trips to work or } \\
\text { school/university }\end{array}$ & & & & & & \\
\hline $\begin{array}{l}\text { Some commute trips to work or } \\
\text { school/university }\end{array}$ & & & & & & \\
\hline Trips to the grocery store & & & & & & \\
\hline $\begin{array}{l}\text { Long-distance (one-way distance } \\
\text { greater than 50 mi) leisure trips } \\
\text { with family/friends }\end{array}$ & & & & & & \\
\hline $\begin{array}{l}\text { Long-distance (one-way distance } \\
\text { greater than 50 mi) business trips } \\
\text { with colleagues }\end{array}$ & & & & & & \\
\hline
\end{tabular}

86. Has the COVID-19 pandemic changed your opinion about using emerging transportation technologies such as autonomous vehicles? (Strongly Disagree to Strongly Agree)

87. If autonomous vehicles were available today for your use, what would be your most preferred to way to use them?

a. Own (purchase or lease) AVs and use them only for personal use or use by family members

b. Own (purchase or lease) an AV and earn extra income on the side by making it available to other drivers when not needed

c. Own (purchase or lease) an AV and earn extra income on the side by providing rides for fellow passengers when you use it

d. Rent an $\mathrm{AV}$ as the need arises for personal use or use by family members

e. Use AVs in the form of transportation (taxi, public transit, ride-hailing service) provided by a service provider

f. Use AVs for e-commerce purposes (e.g., delivery of goods and services) provided by a service provider 
88. When the COVID-19 pandemic is no longer a threat, what would be your most preferred way to use autonomous vehicles?

a. Own (purchase or lease) AVs and use them only for personal use or use by family members

b. Own (purchase or lease) an AV and earn extra income on the side by making it available to other drivers when not needed

c. Own (purchase or lease) an AV and earn extra income on the side by providing rides for fellow passengers when you use it

d. Rent an AV as the need arises for personal use or use by family members

e. Use AVs in the form of transportation (taxi, public transit, ride-hailing service) provided by a service provider

f. Use AVs for e-commerce purposes (e.g., delivery of goods and services) provided by a service provider

89. Has the COVID-19 pandemic changed your opinion about using emerging transportation technologies such as autonomous vehicles? (Strongly Disagree to Strongly Agree

THANK YOU! 
